
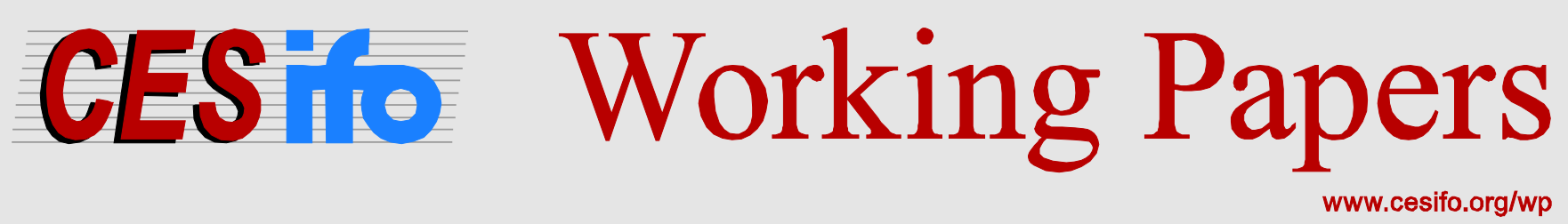

\title{
Going to Extremes: \\ Politics after Financial Crises, 1870-2014
}

\author{
Manuel Funke \\ Moritz Schularick \\ Christoph Trebesch
}

\author{
CESIFO WORKING PAPER NO. 5553 \\ CATEgory 7: Monetary Policy and InTERnational FinanCE \\ OCTOBER 2015
}

An electronic version of the paper may be downloaded

- from the SSRN website:

- from the RePEc website:

- from the CESifo website:

WWW.SSRN.com

Www.RePEc.org

www.CESifo-group.org/wp 


\title{
Going to Extremes: Politics after Financial Crises, 1870-2014
}

\begin{abstract}
Partisan conflict and policy uncertainty are frequently invoked as factors contributing to slow post-crisis recoveries. Recent events in Europe provide ample evidence that the political aftershocks of financial crises can be severe. In this paper we study the political fall-out from systemic financial crises over the past 140 years. We construct a new long-run dataset covering 20 advanced economies and more than 800 general elections. Our key finding is that policy uncertainty rises strongly after financial crises as government majorities shrink and polarization rises. After a crisis, voters seem to be particularly attracted to the political rhetoric of the extreme right, which often attributes blame to minorities or foreigners. On average, far-right parties increase their vote share by $30 \%$ after a financial crisis. Importantly, we do not observe similar political dynamics in normal recessions or after severe macroeconomic shocks that are not financial in nature.
\end{abstract}

JEL-Code: D720, G010, E440.

Keywords: financial crises, economic voting, polarization, policy uncertainty.

\author{
Manuel Funke \\ Free University of Berlin \\ John F. Kennedy Institute \\ Department of Economics \\ Berlin / Germany \\ m.funke@fu-berlin.de
}

\author{
Moritz Schularick \\ University of Bonn \\ Department of Economics \\ Bonn / Germany \\ moritz.schularick@uni-bonn.de
}

\author{
Christoph Trebesch \\ University of Munich \\ Department of Economics \\ Munich / Germany \\ christoph.trebesch@econ.lmu.de
}

October 11, 2015

We thank John Ahlquist, Slantchev Branislav, Mark Copelovitch, Henrik Enderlein, Jeffrey Frieden, Mark Hallerberg, Òscar Jordà, Alan Taylor, Stefanie Walter and participants at "The Political Economy of the Euro Crisis" workshops in Berlin and Zurich and the "Post-Crisis Slump" conference in Brussels. Lucie Stoppok provided excellent research assistance. Schularick gratefully acknowledges financial support from the Volkswagen Foundation. 


\section{Introduction}

With the catastrophe of the 1930s in mind, the fear of political radicalization in the wake of economic and financial disasters looms large in public discourse. Recent events in the Eurozone support such concerns. Since 2008, two-party systems that were stable for decades were swept away in the wake of the economic and financial turmoil. New political forces have since entered parliament and gained ground, while others have disappeared from the political map. In many countries, parties on the extreme right such as Front National in France or Golden Dawn in Greece have scored major electoral successes. Populist or openly Eurosceptic parties such as the Five Star Movement in Italy, Podemos, the party of True Finns, the UK Independence Party, or the Alternative for Germany have been surprise winners in recent elections.

Increasing fractionalization and polarization of parliaments makes crisis resolution more difficult, reduces the chances of serious reform and leads to political conflict at a time when decisive political action may be needed most. A number of authors have linked political gridlock to slow recoveries from financial crises. Frieden (2015), Mian, Sufi, and Trebbi (2014) as well as Lo and Rogoff (2015) argued that dysfunctional politics contribute to the now well documented phenomenon of slow recoveries from financial crises (Jordà, Schularick, and Taylor 2013, 2014b). ${ }^{1}$ These ideas complement an important body of work in macroeconomics in recent years that has studied policy uncertainty and its economic effects in more depth (Bloom, Bond, and Van Reenen 2007; Bloom 2009; Bloom et al. 2012; Bachmann, Elstner, and Sims 2013; Baker, Bloom, and Davis 2013). An important insight resulting from this literature is that measured policy uncertainty is particularly high after financial crises. However, with few exceptions, there is limited empirical evidence on the underlying channels. ${ }^{2}$

What has history to say about the political after-effects of financial crises in modern democracies? Can we, over the long-run of modern history, identify systematic shifts in

\footnotetext{
${ }^{1}$ Polarization and fractionalization may also have longer-term repercussions on the political economy. For example, Alesina and Tabellini (1990) and Azzimotti (2011) predict that more polarized political systems produce economic inefficiencies, higher debt, and lower growth. Alt and Lassen (2006), Lindqvist and Östling (2010), Azzimonti and Talbert (2014) and Azzimonti (2015) provide empirical evidence supporting this view.

${ }^{2}$ An exception here are Baker et al. (2014) who show that political polarization was an important driver for the increase in US policy uncertainty since the 1960s.
} 
voting behavior after financial crises? And if so, in which direction? Does the extreme left or the extreme right gain, or both? To answer these questions, we examined the political aftermath of all major financial crises in advanced economies since the late 19th century. We also assembled the most ambitious and comprehensive historical dataset of election results and parliamentary composition to date, covering 20 countries and spanning 140 years with more than 800 elections between 1870 and 2014 .

Our first key finding is that financial crises are followed by important changes in voter behavior that in turn, contribute to high levels of policy uncertainty. Political polarization increases after financial crises throughout the 19th and 20th century. Moreover, political parties on the far right appear to be the biggest political beneficiaries of a financial crash. On average, far-right parties have seen an increase in their vote shares of about $30 \%$ relative to their pre-crisis level in the five years following a systemic financial crisis. These findings echo a recent study by de Bromhead, Eichengreen, and O'Rourke (2012), who focus on the electoral consequences of crises in the 1920s and 1930s. We show that the gains of far-right parties were not limited to the interwar period: In recent decades, far-right parties, including populist parties of the so-called "New Right", also saw broad-based electoral gains. After financial crises, voters seem to be systematically lured by the political rhetoric of the far right, with its frequently nationalistic or xenophobic tendencies. Moreover, we identify an important asymmetry in the political response to crises: on average, the far left did not profit equally from episodes of financial instability. ${ }^{3}$

Our second main insight is that governing becomes more difficult after financial crises, irrespective of which parties are in power. In particular, after World War II, crises are associated with shrinking government majorities, a strengthening of opposition and greater political fractionalization. This in turn is associated with a higher probability of government crises and changes in the executive branch. We thus confirm the finding of Mian, Sufi, and Trebbi (2014) that political fractionalization increases in the aftermath of financial crises after 1980. However, using the depth of our historical dataset we can show that these effects have become stronger over time.

Third, we document that street protests increase dramatically in the aftermath of finan-

\footnotetext{
${ }^{3}$ This finding somewhat contradicts Giuliano and Spilimbergo (2014) who link recession experiences to distrust in institutions, leading to more right voting, as well as to more support of government intervention/redistribution, resulting in more left voting.
} 
cial crises. Riots, strikes and demonstrations can be seen as an additional proxy for political constraints on governing. Passarelli and Tabellini (2013) have recently demonstrated how social unrest may negatively impact policy-making in democracies.

These results are robust to controlling for macroeconomic and financial conditions as well as political factors such as electoral systems, voter turnout, suffrage and different government systems.

On the methodological side, we use the statistical toolkit of local projections (LPs) pioneered in Jordà (2005) and project the path of political variables over a five and ten year horizon following the beginning of a financial crisis recession. As in Jordà, Schularick, and Taylor (2013; 2014a; 2014b), we compare the political aftermath of crisis recessions to the aftermath of (non-financial) recessions. We find that the political effects of financial crises are particularly more pronounced than those of normal recessions that tend to have little or no effects on political variables.

A potential concern with these findings is that financial recessions could be deeper than normal recessions and as a result the observed effects are due to the severity of the recession and not to the financial crisis. In the spirit of Barro and Ursúa (2008), we then compare financial crisis recessions to other severe macroeconomic "disasters" that do not involve a financial crash. We find that the effects are much more pronounced in financial crises and conclude that financial crashes stand out since their political after-effects are particularly disruptive.

On the data side, a core contribution of this paper is the compilation of a rich new dataset that will benefit future research in the field. Our newly compiled data covers the near universe of systemic financial crises and general elections in 20 advanced economies since 1870. Since financial crises are rare events, many researchers in this field have opted to go back in time and use longer time spans of data to study crises and their consequences (e.g., Reinhart and Rogoff 2009a, 2009b, 2015; Schularick and Taylor 2012; Perri and Steinberg 2012; Kose, Loungani, and Terrones 2013; Jordà, Schularick, and Taylor 2013, 2014a; 2014b). We focus on advanced economies and intentionally avoid blending the experience of developing and advanced economies. We study systemic banking crises only and avoid less precise definitions of financial crises that, to varying degrees, encapsulate inflation spurts, stock market crashes, currency crashes and sovereign defaults. For the 
coding of systemic banking crises, we rely on the papers by Jordà, Schularick, and Taylor (2013; 2014a).

This paper is part of a growing literature on the political consequences of financial crises. The majority of existing studies focus on individual countries or shorter time windows. ${ }^{4}$ An exception is Chwieroth and Walter (2013) who study leadership turnover during and after banking crises in 20 developed and developing countries since $1830 .{ }^{5}$ Our analysis differs from these previous studies in that we focus on political responses to economic crises in a broad sense, and not only on government survival or leadership turnover. ${ }^{6}$ We are aware of only one paper with a similar focus, namely that of Mian, Sufi, and Trebbi (2014). Moreover, we are the first to study the link between crises and social unrest for a broad cross-country dataset, wich corroborates Ponticelli and Voth's (2011) analysis of the political effects of austerity policy.

The structure of the paper is as follows. In the next section we introduce our dataset; in the third section we discuss the statistical design. The fourth section contains the empirical core of our study: we demonstrate the electoral successes of far-right parties, the increase in political polarization and fragmentation, and its link to instability and uncertainty. In the fifth section we compare financial crises to severe and normal non-financial recessions as well as to other macro disasters. The last section of this paper concludes and summarizes our findings.

\section{Data}

In this study, we draw on a broad set of historical data. This section describes the main variables used in our analysis, all measured at annual frequency and for the following 20

\footnotetext{
${ }^{4}$ See Eichengreen (1992); Haggard (2000); MacIntyre (2002); Bernhard and Leblang (2008); CrespoTenorio, Jensen, and Rosas (2012); de Bromhead, Eichengreen, and O'Rourke (2012).

${ }^{5}$ They use the Reinhart and Rogoff (2009b) crises dating and follow the approach by Crespo-Tenorio, Jensen, and Rosas (2012) to measure political turnover risks. Their main result is that governments are more likely to lose power following a financial crisis today, compared with during the 19th or early 20th century. Their interpretation is that citizens' awareness of the ability of the government to manage the economy increased dramatically in the wake of the Great Depression and World War II. Another recent long-run analysis is by Ahlquist, Anselly, and Lindvall (2014), who find that the political cost of exiting a fixed exchange rate regime is high, both before and after World War II.

${ }^{6}$ Specifically, we consider the vote share of government coalitions regardless of whether they were the government that led the country into the crisis or were the one that replaced it. We are not mainly interested in the (somewhat unsurprising) punishment of poor economic policy-making and crisis management by incumbent governments, but in the general ability of a country to establish political stability and leadership in the aftermath of a financial crisis.
} 
developed economies: Australia, Austria, Belgium, Canada, Denmark, Finland, France, Germany, Greece, Ireland, Italy, Japan, the Netherlands, Norway, Portugal, Spain, Sweden, Switzerland, the United Kingdom and the United States. Appendix Table A1 lists the definitions and sources for our main variables, and Appendix Table A2 shows the summary statistics.

\subsection{Election results and parliamentary composition, 1870-2014}

We compiled an archive of 827 parliamentary elections from throughout history. This new dataset, encompassing the years from 1870-2014, includes detailed information on general elections to the national parliaments of the 20 countries in our sample. Presidential elections, non-nationwide (regional or local) elections and referendums are excluded. In case of two or more elections in one year (e.g., Greece in 2012), we count the last election in that year. In the case of bicameral legislatives (e.g., in the United States), only elections to the lower chamber are considered (e.g., the US House of Representatives). Altogether, we identified 859 elections, but could not find sufficient data for 32 of these. Therefore, the final sample includes 827 election events. ${ }^{7}$ Appendix Table B1 gives an overview of which parliamentary elections we coded and shows the names of the respective parliaments/chambers as well as cases with missing data. The information on vote shares and on the distribution of seats in parliament come from three main sources, namely Döring and Manow (2012), Mackie and Rose (1974) and Nohlen and Stöver (2010). In addition, we drew on a series of country-specific sources, which are also listed in Appendix B.

Based on the raw data, we group the vote shares along several dimensions. First, we add together votes of anti-system parties, i.e., vote shares of parties on the far left or the far right, which seek to change the system of government per se (see Sartori 1976). To categorize parties as far-right or far-left we follow de Bromhead, Eichengreen, and O'Rourke (2012) for the interwar period (1919-1938). Extremist parties in the pre-1919 period are ignored, simply because there are no sufficient sources for a clean classification. For the

\footnotetext{
${ }^{7}$ Another reason for missing data were institutional factors. In the 19th century, some parliaments consisted merely of unlinked, nonpartisan candidates from various constituencies. It was therefore not possible to assign members to parties and to compute vote and seat shares. This was the case in the Dutch general elections from 1871-1887 (Mackie and Rose 1974, p. 267), the Norwegian parliamentary elections 1870-1879 (Rokkan 1967, p. 376) and the Swedish general elections from 1872-1884 (Stjernquist 1966, p. $120)$.
} 
period after 1939, we track the parties coded as extremist by De Bromhead, Eichengreen, and O'Rourke (2012), and their follow-up or splinter formations. Furthermore, we identify newly formed parties on the extreme left and right by assessing the political platform of each party gaining more than $0.1 \%$ of the vote in our post-World War II sample of elections. For this purpose we draw on Betz (1994), Ignazi (2003), Minkenberg (1998; 2001; 2008), Minkenberg and Perrineau (2007), Mudde (2000; 2005; 2007), country reports by Bertelsmann Stiftung (2009), as well as large number of country-specific sources listed in Appendix B.

In the spectrum of far-right parties, we include parties of the "New Right", i.e., those parties in the grey area between far-right extremism and right-wing populism. This follows the widespread view in political science literature that the profile of the political far right has undergone fundamental changes since World War II (e.g., Betz 1994; Ignazi 2003). Many parties discarded openly fascist and anti-democratic attitudes and adopted a more moderate tone in reference to ethnocentrism, nationalism and secessionism, most recently often combined with a Eurosceptic platform. On the far left, we include all parties that take up traditional communist and/or Marxist-Leninist positions. Similar to the right wing views, we also include parties that would not be identified as communists in the traditional sense, but included those who refuse contemporary international economic order and base their national economic policies an anti-capitalist ideology (e.g., "The Left" in Germany). Some of these parties can also be classified in the populist, Eurosceptic spectrum. For example, we code the "United Left" in Spain and the Italian anti-establishment party "Five Star Movement" as far-left parties. Appendix Table B2 provides further details and shows all parties classified as far-right and far-left in our sample.

Second, we add up the government vote share by combining the votes of the governing party or of parties in the governing coalition, as well as the opposition vote share, which is done by combining the vote share of all parties in the opposition. This was possible to do for most countries since 1870, although we exclude elections in monarchies in the early years of the sample, i.e., of the German Reich, Denmark, Finland (under Russian occupation), Japan, Norway, Portugal, Spain and Sweden. We also exclude elections in the fascist and military dictatorships of Germany (1933-1945), Italy (1924-1945), and Portugal 
(1926-1974). ${ }^{8}$ The distinction between government and opposition does not make much sense for these countries during those time periods. We again refer to Appendix Table B1, which gives a condensed overview of the elections in our sample and their characteristics.

To identify government and opposition we draw on a wide range of sources, in particular Döring und Manow (2012), as well as a series of country-specific sources listed in Appendix B. In parliamentary systems, we code those parties that were represented in the cabinet as government parties. In presidential systems, we code only the president's party as the government party, while all remaining parties are coded as opposition parties. We exclude independent candidates without party affiliation, since they may switch sides depending on the law that is under consideration (this follows Mian, Sufi, and Trebbi 2014). If there is a change in power in a given year, we code the vote shares of the newly elected government, not of the outgoing one. ${ }^{9}$

Lastly, we code two measures on the degree of parliamentary fragmentation based on the raw data on seats in parliament. ${ }^{10}$ First, we simply count the number of parties in parliament. Second, we consider the distribution of parliamentary seats among parties following the more sophisticated approach implemented by Beck et al. (2001). Specifically, we code a long-run measure of fractionalization, which is defined as the probability that two representatives picked at random from among the parties in the legislature will be of different parties. More formally this can be written as:

$$
\text { legislativefractionalization }=1-\sum_{i=1}^{n}\left[\frac{\left(n_{i}-1\right) \frac{n_{i}}{N}}{N-1}\right]
$$

where $n=$ number of parties, $n_{i}=$ seats held by the $n$-th party, and $N=$ total seats in the parliament. Of course, in this context of course the definition of "party" is crucial. See Appendix B for details on the coding of this variable. The fractionalization measure is bound between 0 and 1 . The lowest value of 0 indicates no fractionalization, while the value of 1 indicates maximal fractionalization.

\footnotetext{
${ }^{8}$ There were no elections in Spain from 1936-1974 and in Greece from 1937-1941 and from 1967-1973.

${ }^{9}$ Whenever government formation after an election exceeds the turn of a calender year (e.g., in the United States) we record the year in which the election took place. In cases of interim governments we denote the next partisan government that took office.

${ }^{10}$ To go as far back as possible, these measures are computed for all elections, except for the elections held during the dictatorships in Germany from 1933-1945, in Italy from 1924-1945, and in Portugal from 1926-1974. In other words, we explicitly include monarchies with a legislature. However, the results are also robust to when monarchies are excluded.
} 


\subsection{Street protests, 1919-2012}

In addition to the parliamentary variables, street protests are good indicators of political radicalization and serve as a proxy for political instability in the post-crisis period (see, for example, Ponticelli and Voth 2011; Passarelli and Tabellini 2013). To approximate street protest we rely on the dataset of Banks and Wilson (2014), which provides information on the annual frequency of domestic conflict events from 1919 to 2012 (excluding the World War II period from 1940 to 1945). In particular, we consider the number of general strikes, defined as "any strike of 1,000 or more industrial or service workers that involves more than one employer and that is aimed at national government policies", the number of violent riots, defined as "any violent demonstration or clash of more than 100 citizens involving the use of physical force", and the number of anti-government demonstrations, defined as "any peaceful public gathering of at least 100 people for the primary purpose of displaying or voicing their opposition to government policies". We use the sum of these three variables as our baseline variable - termed street protests - to measure the overall degree of open protest in the street.

In comparison to our other dependent variables, street protests show strong time trends, which is evident when looking at Figure $\mathrm{C} 1$ in the appendix. The degree of social unrest is very volatile and can double from one decade to another; our data shows peaks during the 1960s and 2010s. At the same time, there is on average long periods with little street protest, e.g. the 1980s and 1990s. To deal with time trends in the data, we decomposed the variable into a trend and cycle component. Specifically, we apply the widely used Hodrick Prescott filter (see Hodrick and Prescott 1997) with a smoothing parameter of 6.25. Using it as dependent variable, we then compute the percent deviation from trend for the street protest variable. This reduces the risk of spurious inference, but also makes the results somewhat harder to interpret.

\subsection{Financial crises and recessions}

Financial crises are defined as events during which a country's banking sector experiences bank runs, sharp increases in default rates accompanied by large losses of capital that 
result in public intervention, bankruptcy, or forced merger of financial institutions. ${ }^{11}$ Dates of systemic financial crises are based on the study by Jordà, Schularick, and Taylor (2013), which build on the timing of historical crisis events pioneered by Bordo et al. (2001) and Reinhart and Rogoff (2009b). The Laeven and Valencia $(2008,2012)$ dataset of systemic banking crises is the main source for post-1970 crisis events. Appendix Table D1 shows a full list of the 103 financial crises in our dataset.

Besides financial crisis dates, we also determine the dates of recessions following the data and methodology in Jordà, Schularick, and Taylor (2013). Specifically, we generate two auxiliary dummy variables using the intuition in the Bry and Boschan (1971) algorithm to capture business cycle features in the data. This algorithm separately generates dates of peaks and troughs in economic activity for each country in our sample. Using real GDP per capita, a peak corresponds to a local maximum and a trough corresponds to a local minimum. A recession is defined as the period between a peak and the following trough, whereas an expansion is defined as the period between the trough and the subsequent peak.

For the empirical analysis, we then make the distinction between recessions that coincide with a major financial crisis - termed financial crisis recessions - and those without major financial disruptions - termed normal recessions. More precisely, we call a recession financial if a major financial crisis erupts within a two year window around the peak of the cycle. Appendix Table D2 shows the full list of financial and normal recessions in our dataset. Benchmarking normal vs. financial recessions allows for cleaner identification of the effects of financial crises rather than comparing financial crises spells to a counterfactual of all other years. However, normal recessions are typically less severe than financial recessions. Therefore, as a second benchmarking exercise, we also compare financial recessions to a subset of normal recessions that are particularly deep. In the spirit of Barro (2006) and Barro and Ursúa (2008; 2011), we term these severe normal recessions as non-financial macro disasters. Specifically, we keep only those non-financial recessions with an average GDP p.c. decline that is higher than the average GDP decline during financial recessions. We apply this cut-off separately for the pre-World II sample (with a threshold of $-3.35 \%$ ) and for the post-World War II sample (with a threshold of -2.55\%).

\footnotetext{
${ }^{11}$ Jordà, Schularick, and Taylor (2014a) emphasize the distinction between isolated banking failures (such as the demise of Baring Brothers in the U.K. in 1995) and systemic distress (such as the Global Financial Crisis 2008). However, their systemic financial crisis classification has proven valuable in previous studies.
} 
The end result is a list of non-financial macro disasters provided in Appendix Table D3. On average, these events see a GDP contraction of $5.82 \%$ per year. The results are similar if we use a full-sample average, or if we use the median GDP contraction as a cut-off. Similarly, the results are roughly the same if we apply an even stricter threshold and only consider the worst $25 \%$ normal recessions (those with the highest GDP contractions).

\section{Statistical design}

For each dependent variable, we start with a preliminary view of the data, including summary statistics, visual plots of the data and OLS panel regressions. We then take the time dimension more seriously and estimate local projections (LPs) following the method pioneered by Jordà (2005) and applied in a range of closely related studies (Jordà, Schularick and Taylor 2011; 2013; 2014a). Moreover, we provide a range of robustness checks of our estimates.

In a first step, we compare pre-crisis spells with post-crisis spells following Mian, Sufi, and Trebbi (2014). Specifically, we restrict the sample to a full five years before and a full five years after a financial crisis, excluding the crisis year itself. In cases of follow-up crises, where the five year pre-crisis horizon and the five year post-crisis horizon overlap, we exclude subsequent crises as we interpret them as after-effects of the initial crisis. Note that crises where either the crisis event itself or one of the five year windows coincides with years of global wartime (1914-1918 and 1939-1949) are omitted from the sample. We again refer to Appendix Table D1, which also indicates the 67 (of 103) crises that are considered in the descriptive analysis.

In step two, we then expand the analysis to more broadly compare crisis times to non-crisis times, by running fixed effects panel OLS regressions in our full sample. This allows us to tease out post-crisis deviations from the long-run historical average, using more than 100 years of data. Specifically, we start with a 'bare bones' model in which our dependent variables, i.e., election results and parliamentary composition (denoted as $Y_{i t}$ ), are regressed on a post-crisis indicator variable post ${ }_{i t}$ that takes the value of 1 in the five years after a crisis event $\tau$. We only add country fixed effects $\mu_{i}$ to account for unobservable country-specific heterogeneity. This simple model can be written as follows: 


$$
\begin{gathered}
Y_{i t}=\alpha+\beta * \text { post }_{i t}+\mu_{i}+\varepsilon_{i t} \\
\text { where post }_{i t}=\left\{\tau_{i}+1, \ldots, \tau_{i}+5\right\} .
\end{gathered}
$$

Different from the descriptive analysis, however, we do not restrict the post-crisis spell to a full five years. Post-crisis years now include all years within (i.e., up to) five years after a financial crisis event. Again, Table D1 indicates the 94 (of 103) crises included in the baseline OLS regression. We again remove follow-up crises and crises that began during global wartime. ${ }^{12}$

Third, we follow Jordà (2005) and calculate dynamic multipliers. There are several advantages to this approach, which explains its growing popularity. Local projections handle asymmetries, non-linearities, and richer data structures with great ease. We follow Jordà, Schularick, and Taylor (2013) and distinguish between financial recessions and those without major financial disruptions, i.e. normal recessions. The reasoning behind it is that financial crises often go hand in hand with economic recessions. One could therefore argue that the changes in the political environment that a country experiences after a financial crisis are mainly a function of the recession and independent of the financial crisis per se. Therefore, a stricter test for the effects of financial instability on politics is not based on a comparison of financial crisis periods with tranquil times when the economy expands, but it compares financial crises to recession periods, including severe recessions (or macro disasters).

The first type of recession is associated with a financial crisis. The second type is a standard business cycle contraction without a systemic financial event. This results in a chronology of business cycle peaks, where "N" denotes a non-financial business cycle peak, and "F" denotes a peak associated with a systemic financial crisis. Table D2 in the appendix shows the dates of financial crisis recessions and "normal", non-financial recessions in each country. The list of recessions in that table includes the subsample of particularly severe non-financial recessions (macro disasters), which are shown again separately in Table D3 and are defined above. Note that we again exclude any years of

\footnotetext{
${ }^{12}$ Note that Spain and Switzerland experienced a financial crises in 1913. These crises are technically not excluded, but their entire coincides with World War I.
} 
global wartime (1914-1918 and 1939-1949) in the analysis.

The fixed-effect regressions discussed above resemble unconditional averaging in the sense of a basic event-study approach à la Romer and Romer (1989) in which every occurrence is treated identically. Yet such an approach may not provide sufficient economic structure as economies are complex and dynamic systems. In the local projection set-up we control for observable macroeconomic factors that might impact the post-crisis trajectory of a country. As a proxy for overall economic conditions, we include the growth rate of real GDP per capita as well CPI inflation. However, we also tested the robustness of our results with additional variables such as loan growth and public debt. ${ }^{13}$ The long-run data comes from the macroeconomic database compiled by Jordà, Schularick, and Taylor (2013). ${ }^{14}$ By controlling for economic factors with more variables and more complex dynamics, we make it far less likely that financial crises per se are an independent driver of political reactions and not a function of economic conditions.

Our treatment variables will simply be the occurrence of a financial or normal recession (including non-financial macro disasters). Clearly, the term treatment does not necessarily have to be interpreted in a causal sense. The notation works as follows. $N$ and $T$ denote the cross-sectional and time dimension of the panel. $Y_{i t}$ is a vector of political and macroeconomic variables. For any variable we want to estimate the change in that variable from the beginning of the recession (previous peak) at time $t$ to time $t+h$.

We will calculate this response by estimating a fixed-effects panel model with a discrete treatment depending on whether the recession is financial or not $(N, F)$ :

$$
\begin{aligned}
& \Delta_{h} y_{i t+h}^{k}=\alpha_{i}^{k}+\theta_{N}^{k} N+\theta_{F}^{k} F+ \\
& +\sum_{j=0}^{p} \Gamma_{j}^{k} Y_{i t-j}+u_{i t}^{k} ; \quad k=1, . ., K ; \quad h=1, \ldots, H
\end{aligned}
$$

where $\theta_{N}^{k}$ is the normal recession treatment $(N=1)^{15}$ and $\theta_{F}^{k}$ is the financial recession treatment $(F=1)$. In addition, lags of the control variables $Y$ at time $t$ are included, as are $\alpha_{i}^{k}$ country fixed effects; also $u$ is the error term.

\footnotetext{
${ }^{13}$ This, however, did not significantly affect our main results and our sample often shrank considerably.

${ }^{14}$ For a more detailed documentation of their sources, please refer to their study directly.

${ }^{15}$ In the more restrictive benchmarking exercise with non-financial macro disasters, we only consider those non-financial business cycle peaks " $N$ " that are followed by particularly deep recessions (see above) and set milder recessions to zero.
} 


\section{Going to extremes: politics after financial crises}

In this section we present and discuss the historical evidence that the political climate changes substantially after financial crises leading to greater political instability and uncertainty. More specifically, we will present three main stylized facts from 140 years of modern political economy. First, politics take a "hard right turn" after financial crises. Both before and after World War II, we observe a significant increase of votes for far-right parties. In contrast, parties on the far left of the political spectrum did not have comparable electoral successes after crises. Second, we also find that political polarization increases substantially after financial crises as measured by weaker government majorities, a stronger opposition and a greater fractionalization of parliaments. These effects are considerably more pronounced after World War II than before. Finally, we show that street protests typically increase after financial crises, then and now.

\subsection{Increasing polarization: hard right turns}

A striking result of our election coding effort is the strong evidence for the rise of extremist parties in the aftermath of financial crisis, in particular for far-right parties. This is true for both before and after World War II. Starting with some simple descriptive statistics, Figure 1 shows average vote shares of far-left and far-right political parties five years before and five years after financial crisis events between 1919 and $2014 .{ }^{16}$ Far-right voting increases from about $6 \%$ to about $10 \%$ of the vote following a financial crisis. In contrast, we do not observe a strong post-crisis increase in far-left voting.

\subsubsection{Some historical narrative}

The electoral gains of far-right parties have been particularly pronounced after the global economic crises of the 1920s/1930s and after 2008. In the interwar period, the most prominent cases are Italy and Germany. Mussolini's fascist alliance benefited from the early 1920s banking crisis in Italy and the global recession after the end of World War I, earning $19.1 \%$ of the vote in 1921 and about $65 \%$ in 1925. In Germany, the Nazis won $18.3 \%$ of the vote in the 1930 elections, more than $30 \%$ in the two 1932 elections, and over

\footnotetext{
${ }^{16}$ We exclude crises that erupt within less than five years after a preceding crises as well as crises where either the pre-crisis or post-crisis overlaps with a period of global wartime (see data section above).
} 
Figure 1: Vote shares of the far right and left

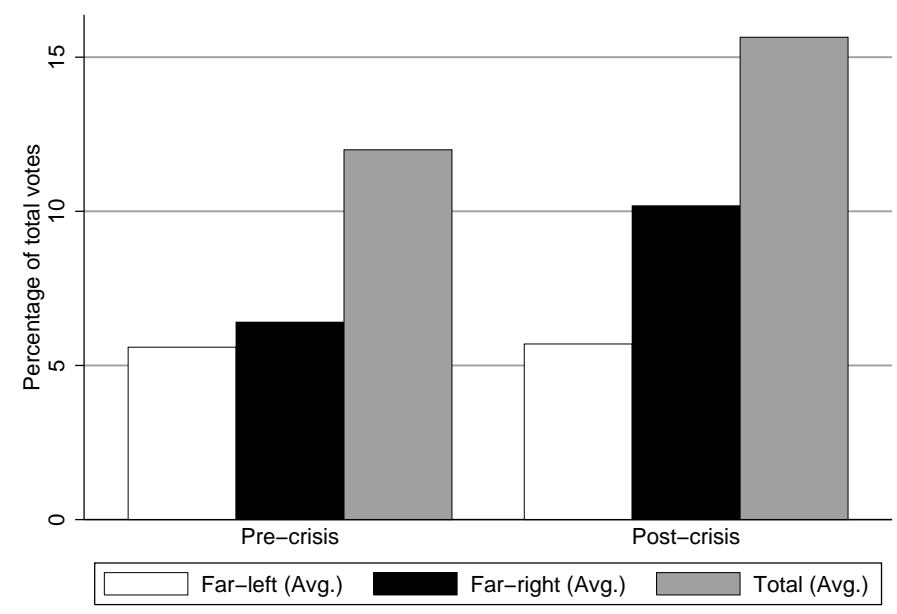

Notes: The figure shows average vote shares of far-left (white columns) and far-right (black columns) political parties. The grey columns represent the sum of the two. The left panel refers to average vote shares in the five years before the start of a financial crisis and the right panel shows average shares in the five years after. The differences are statistically significant at the $5 \%$ level, except for the far-left vote share, which does not significantly increase in the post-crisis period. Table D1 shows the crises included.

40\% in the March 1933 elections, when the Great Depression had its strongest impact on Central Europe. However, during the 1930s far-right parties also had increased electoral success in Belgium (the Rexists and the Flemish National Union), Denmark (the National Socialist Workers' Party), in Finland (Patriotic People's Movement), in Spain (Falange) and in Switzerland (National Front).

In the aftermath of the 2007-08 global crisis, far-right and right-wing populist parties more than doubled their vote share in many advanced economies, including France, the UK, Sweden, Finland, the Netherlands, Portugal and Japan. For example, the Sweden Democrats improved their vote share from $2.9 \%$ in 2006 to $5.7 \%$ in 2010 . In the Netherlands, the right-wing populist Party for Freedom gained almost 10 percentage points following the 2007 crisis (5.9\% in 2006 vs. $15.5 \%$ in 2010). In France, the Front National party earned $13.6 \%$ in 2011 , in the first election following the crisis, compared to just $4.3 \%$ in 2007. Similarly, we find that the vote share of the True Finns party skyrocketed from $4.1 \%$ in 2007 to $19.1 \%$ in 2011.

These patterns can also be seen when using supplementary data from elections to the European Parliament in 2004, 2009, and 2014. Due to the short history of the European 
parliament, this data is not used in the remainder of the paper, but they are illustrative of the trends observed above, also because the electoral rules and voting dates are the same for all EU countries. As we show in Figure 2, the vote share of far-right parties increased in the majority of countries over time, with an especially strong spike between the 2009 and 2014 elections in the wake of the European financial crisis. Among the countries in our sample, the largest electoral gains were made by the Front National party in France. UKIP in the United Kingdom and the Danish People's Party also showed massive gains in the 2014 elections. On average, the far-right vote share approximately tripled between 2004 and 2014.

Figure 2: Far-right and right-wing populist votes in European elections

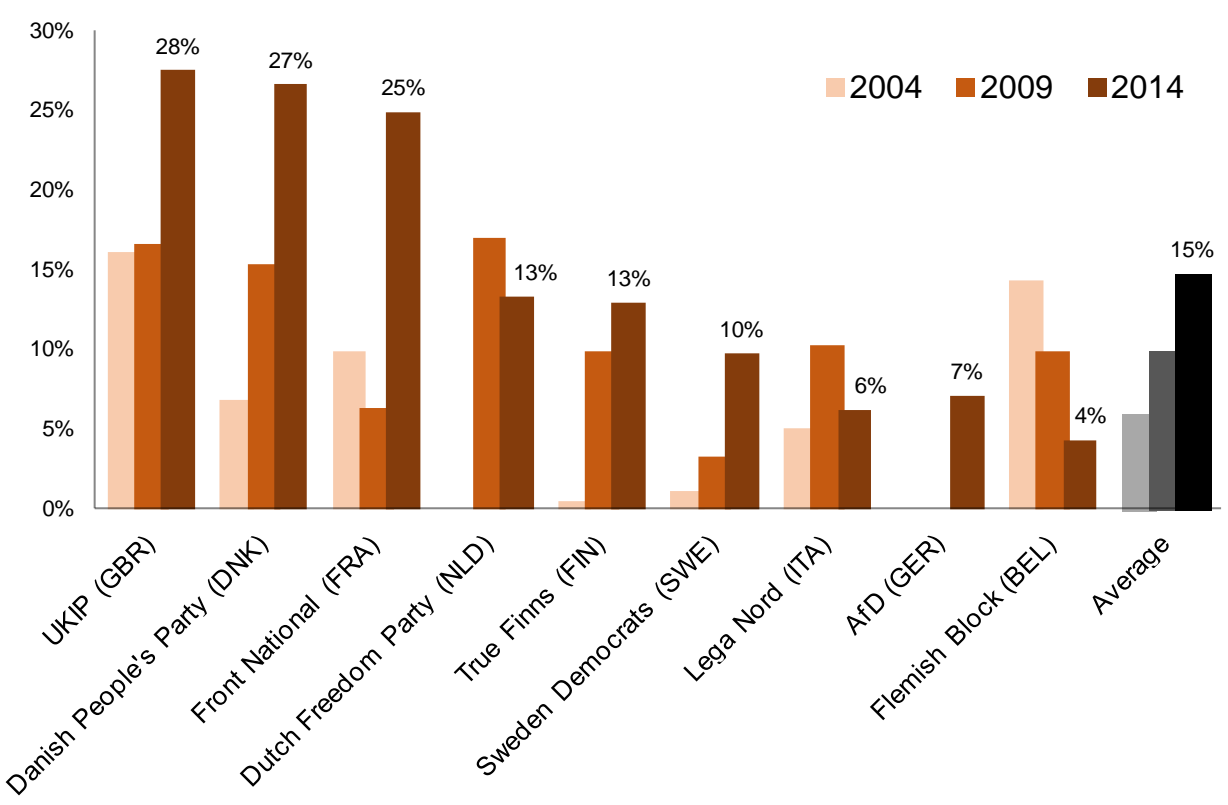

Notes: The figure shows the vote shares of far-right and right-wing populist parties in the European Parliamentary elections 2004, 2019, and 2014. These 9 EU countries are also included in the main analysis. The figure is for illustration only, since electoral data from the European Parliament are not used in the remainder of the paper. The grey columns show averages.

Importantly, however, the observed shift to the right is not only a phenomenon of the "Great Depression" of the 1930s and the "Great Recession" of the late 2000s. As we will illustrate below, our results hold even when these two significant episodes are excluded. Indeed, hard right turns are also observed following more regional financial crisis events, for instance the late 1980s/early 1990s Scandinavian banking crisis. In Norway, the right-wing populist Norwegian Progress Party won just $3.7 \%$ of the vote in 1985. In 1989, in the first 
election after the financial crisis of 1987 , the same party won $13 \%$ of the vote and became the third political force. Also its Danish counterpart, the Danish Progress Party, more than doubled vote shares from $3.6 \%$ in 1984 to $9 \%$ in 1989, becoming the fifth political force in the first election after the crisis. Prior to the Swedish financial crisis of 1990, right-wing parties earned below 1\% of the vote in the 1988 election. However, after the crisis, in 1991, they won $6.8 \%$ of the vote. The newly founded right-wing populist party "New Democracy" gained an impromptu 25 parliamentary seats. ${ }^{17}$

\subsubsection{Empirical results}

These anecdotal observations are strengthened by the results of fixed-effects panel regressions of vote shares on a post-crisis dummy variable (which has the value of 1 for the five years following a financial crisis). To tease out the vote share deviation from the long run historical average, we include all non-crisis years. Table 1 shows the regression results for the full sample (left panel), the interwar period (middle panel) and the post-World War II period (right panel).

Far-right votes increase by almost 5 percentage points after financial crises in the full sample. This difference is significant at the $5 \%$ level. In the post-World War II sample we find a significant (at the 1\% level) increase of 3.8 percentage points in right-wing voting, while the coefficient for the period between 1919-1938 is larger but not statistically significant. The interwar increase in extremist voting is partly driven by two of the 20 advanced countries in our sample, Germany and Italy, while the post-crisis shift to the far right after World War II is a more widespread phenomenon. Accordingly, once we remove the country fixed effects, we find a significant coefficient of 4.6 for far-right votes after crises in the pre-World War II sample.

Figure 3 shows local projections of the cumulative change in far-right vote shares for years $1-5$ of the financial recession (red line), controlling for real GDP growth and inflation (and their lags). The shaded region is a 90\% confidence interval. Analogous to the OLS

\footnotetext{
${ }^{17}$ Other examples include the 1991 financial crisis and subsequent economic stagnation in Switzerland, where the Swiss People's Party achieved about $11 \%$ of the vote during the 1980s, and then improved its vote share to $15 \%$ in 1995 and then to $22.5 \%$ in 1999. During this same period, the 1990 Italian financial crisis was followed by the sudden rise of the federalist and right-wing populist North League party. This party increased its vote share from just $1.3 \%$ in the 1987 elections to $8.7 \%$ in the post-crisis elections of 1992 and was a relevant political force throughout the 1990s.
} 
Table 1: Far-right and far-left vote shares: post-crisis years vs. normal years

(a) Full sample (b) Pre-WWII

(c) Post-WWII

\begin{tabular}{|c|c|c|c|}
\hline \multicolumn{4}{|c|}{ Far-right vote share } \\
\hline Post-crisis & $\begin{array}{c}4.903^{* *} \\
(2.337)\end{array}$ & $\begin{array}{c}4.498 \\
(4.474)\end{array}$ & $\begin{array}{r}3.770^{* * *} \\
(1.098)\end{array}$ \\
\hline$R^{2}$ & 0.028 & 0.017 & 0.056 \\
\hline Obs. & 1538 & 317 & 1221 \\
\hline \multicolumn{4}{|c|}{ Far-left vote share } \\
\hline Post-crisis & $\begin{array}{l}-1.223 \\
(1.090)\end{array}$ & $\begin{array}{l}-0.223 \\
(0.388)\end{array}$ & $\begin{array}{c}0.437 \\
(1.034)\end{array}$ \\
\hline$R^{2}$ & 0.010 & 0.001 & 0.001 \\
\hline Obs. & 1538 & 317 & 1221 \\
\hline
\end{tabular}

Notes: This table compares the post-crisis levels of far-right and far-left vote shares to their average level. The time window for post crisis is five years. Robust standard errors (clustered by country) are shown in parentheses. Regressions controlled for the growth rate of GDP per capita growth and the CPI inflation rate (not reported). The left panel covers the years 1919-2014, excluding World War II, the middle panels 1919-1938, and the right panels 1950-2014. Table D1 shows the crises included. $* * *$ Significant at .01. ${ }^{* *}$ Significant at .05. * Significant at .1 .

regressions, we show results in the full sample with all recessions (left panel), pre-World War II recessions (middle panel) and post-World War II recessions (right panel). The figure points to a constant upward trend in far-right voting after financial recessions in the full sample, and both before and after World War II. The same can be seen in the corresponding results in Table 5 in the text below. On average, far-right votes increase by $30 \%$ (not percentage points) in the five years after financial recessions.

These results are robust when we exclude the dictatorship spells from the pre-World War II sample in Austria and Germany from 1933-1938 and in Italy from 1924-1938 (Spain had no elections during the rule of Franco). Second, the results also hold when we remove the Great Depression and the 2007-08 global financial crisis from the sample.

We also tested the robustness of our results by controlling for additional characteristics of each election and of the country's voting system, in particular voter turnout (by election, in \%), suffrage (population eligible to vote, by election, in \%), a dummy for presidential vs. 
Figure 3: Far-right vote shares (local projections): financial crisis recessions

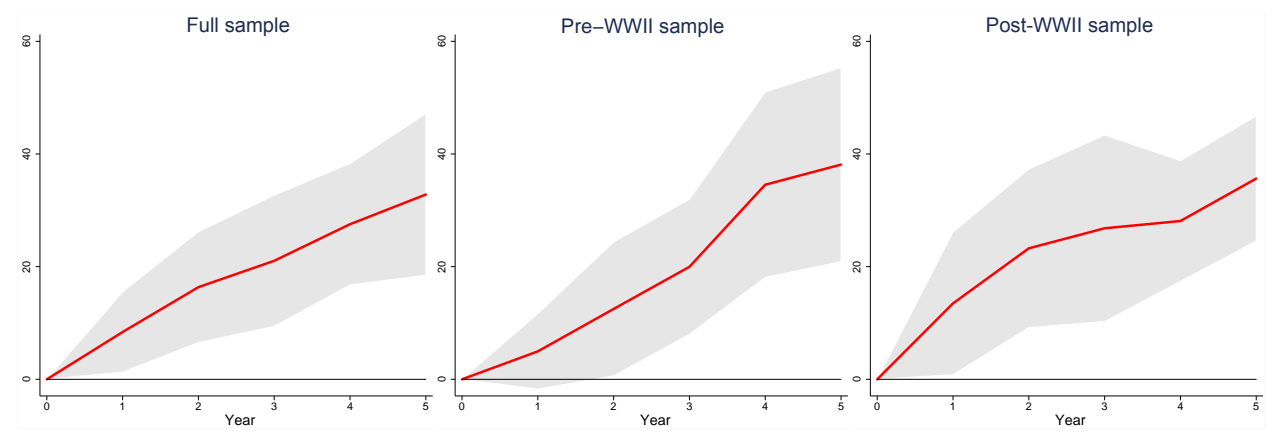

Notes: Each path shows local projections of the cumulative change relative to peak for years $1-5$ of the recession/recovery period. The red line refers to the average path in financial crisis recessions and the shaded region is a $90 \%$ confidence interval. The controls are contemporaneous and 1-year lagged values of the growth rate of GDP per capita and the CPI inflation rate at peak. The left panel covers the years 1919-2014, excluding World War II, the middle panel 1919-1938, and the right panel 1950-2014. Table D2 shows the recessions included. The dependent variable is the combined vote share of all electorally successful far-right political parties in the most recent general election. For the corresponding regression results see Table 5 in the text below.

parliamentary system and a dummy for proportional representation vs. first-past-the-post system. ${ }^{18}$ The latter measures are important, since presidential democracies and those with first-past-the-post voting systems typically have a less fragmented legislature and tend towards a two-party system (e.g., Lijphart 1994; Horrowitz 2009), which could bias our results. However, none of the additional control variables changed our results on far-right voting in a meaningful way.

Finally, we divide the group of far-right parties into those of the "Old Right" and those of the "New Right" (see chapter 2.1). We find that the postwar results are mainly driven by the latter, meaning that right-wing populist parties benefited more than traditional fascist and neo-Nazi parties of the extreme right. Nevertheless, traditional far-right parties also see increased vote shares after financial crises in the postwar period; it is just not as pronounced as it is for the populist "New Right" parties such as the UKIP or the Dutch Freedom Party.

\footnotetext{
${ }^{18}$ The data on voter turnout and suffrage comes from the same sources as our electoral data (see appendix). To classify systems of government (parliamentary vs. presidential) we use Banks and Wilson (2014). Information on the history of European and Anglo-Saxon voting systems before 1980 was obtained from McLaren Carstairs (1980) and Ljiphart (1994), respectively. All coding after 1980 follows Beck et al. (2001).
} 


\subsection{Increasing fragmentation: governing becomes more difficult}

In the next part of our analysis, we focus on the measures of political fragmentation and the strength of government outlined above. Figure 4 shows kernel density estimates of government vote shares, opposition vote shares, our measure on the fractionalization of parliament, and the number of parties in parliament (horizontal panels). Again, we distinguish between the full sample of crises, pre-World War II crises, and post-World War II crises (vertical panels). For each variable, we show kernel densities for the five years prior to a financial crisis (black line) and the five years afterwards (red line).

The figure suggests notable changes in the political response to crises over the past 140 years. In the contemporaneous sample (after World War II), overall fractionalization increases, the number of parties in parliament grows, governments appear weaker, and opposition forces strengthen (in terms of vote shares) after a financial crisis relative to before the crisis. In contrast, the picture is less clear in the pre-World War II period, at times even moving in the opposite direction with regard to government support and opposition forces. Similarly, both parliamentary fractionalization and the number of parties seem to decline post-crisis rather than increasing. Thus, it seems that the weakening of governing coalitions and the fractionalization of parliaments after crises is a relatively recent phenomenon.

\subsubsection{Historical evidence}

There are many examples for weakening government support and a fragmentation of parliament following financial crises in the post-World War II era. Most notably, the global crisis of 2008 saw a general decline in voter support for the governing coalition and for big tent parties. This was true, for example, in Belgium, Denmark, Germany, Japan, the Netherlands and Portugal, where voter's support for the governing party or coalition decreased by up to 20 percentage points between the last election before the crisis until the first election afterwards. In Spain, for instance, the two main parties that had been alternating power for decades, the People's Party and the Socialist Workers' Party, saw their joint vote share decline from $83.8 \%$ in 2008 to just $73.4 \%$ in 2011 and similar developments could be observed in France and Germany. In Sweden, the centre-right 
Figure 4: Kernel densities of parliamentary variables

Full sample
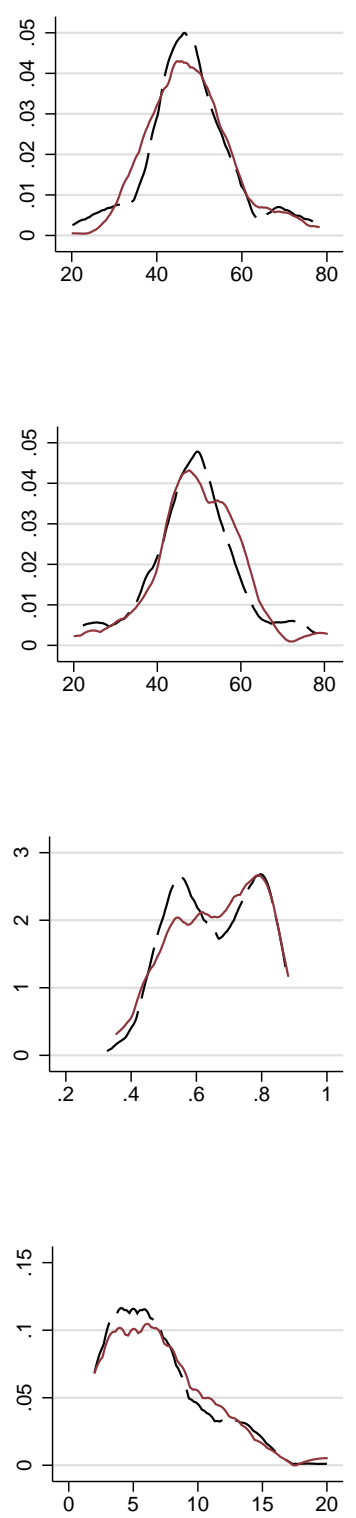

\section{Pre-WW2 sample}

Government vote share

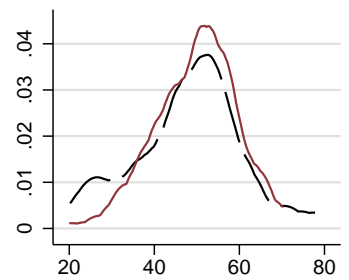

Opposition vote share

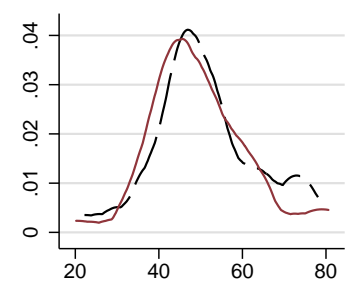

Fractionalization of parliament

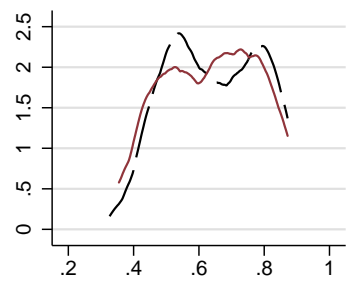

$\mathrm{Nr}$. of parties in parliament

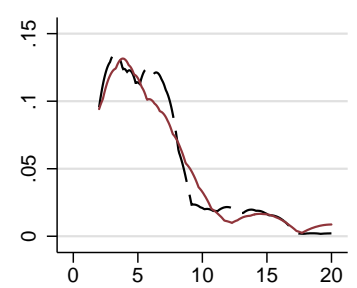

\section{Post-WW2 sample}
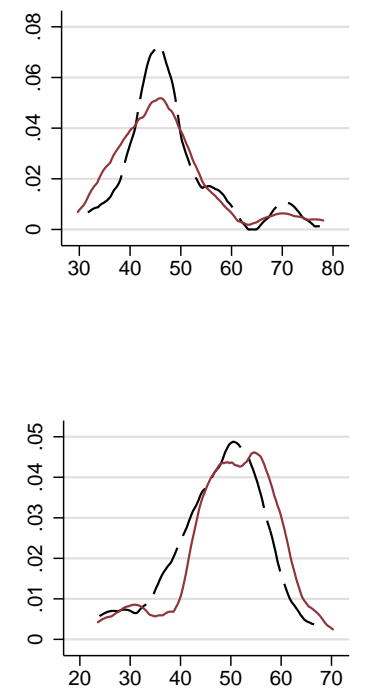

\section{- - - Pre-Crisis $\longrightarrow$ Post-Crisis}

Notes: The figure shows kernel densities of four different parliamentary variables (illustrated by each row of panels). The black dashed line refers to the five years before a financial crisis and the red line to the five years after a financial crisis. The left panels cover crises in the years 1870-2014, the middle panels 1870-1938, and the right panels 1950-2014. Periods of global war (1914-1918 and 1939-1949) are excluded. Table D1 details which crises are included. 
alliance turned from a majority government in the 2006 election to a minority government in the 2010 election. In the United Kingdom, the Conservatives achieved only $47 \%$ of the seats in 2010, which resulted in a hung parliament and a coalition government with the Liberal Democrats, the second such arrangement in British history (the only other coalition government was formed in 1974). Also the Scandinavian banking crisis of the late 1980s and early 1990s was followed by minority governments and weaker governing coalitions, for example the Norwegian cabinet of Jan Syse in the 1989 elections and the Danish government of Poul Schlüter in 1990.

We also find numerous instances of new parties rising and entering parliament in the aftermath of financial crises. In Spain, the number of parties in parliament increased from 10 to 13 in 2011, and two newly founded parties, "Podemos" and "Ciudadanos" are gaining ground, with strong regional and local election results in recent years. In the Italian 2013 elections, a new anti-establishment party named the "Five Star Movement" earned 108 parliamentary seats and $25.5 \%$ of the vote off the cuff, posing a threat to effective governing. Further examples include the Swedish "New Democracy", which was founded and entered parliament after the country's banking crisis of 1990, and Italy's "North League" which won 55 seats in the first election after the outbreak of the 1990 crisis. $^{19}$

There are a few such anecdotes when we go further back in history. Interesting cases include several English-speaking countries during the 1930s, which saw many more parties entering parliament in response to the economic and financial turmoil brought about by the Great Depression. In Australia, the "Emergency Committee of South Australia" arose, winning six parliamentary seats in its first and only contested election in 1931. In Canada, the "Reconstruction Party" and the "Social Credit Party", both founded in 1935, entered parliament instantly. Similarly, in the United States, the populist "Wisconsin Progressive Party", won seven seats in its first contested election in 1934. Moreover, in the United Kingdom, the "Independent Labour Party" broke away from Labour while the "National Liberal Party" broke away from the Liberals before the 1931 elections, both over

\footnotetext{
${ }^{19}$ Similarly, during the mid 1970s crisis in Britain, the separatist parties from Wales (Plaid Cymru) and Scottland (Scottish National Party) entered parliament for the first time. In Japan, the financial crisis of the 1990s was followed by significant changes in the party spectrum, which had been very stable in the preceding decades. In the four elections between 1990 to 2000, six new parties entered parliament, most notably the "New Frontier Party" (156 seats in 1996) and the "Democratic Party of Japan" (52 seats in 1996). The latter won a landslide victory in 2009 and replaced the Liberal Democratic Party, which had been in power almost uninterruptedly since 1955 .
} 
disagreements on how to respond to the severe economic problems of the time. Taken together, these examples illustrate that financial crises have often been followed by notable shifts in the political system.

\subsubsection{Empirical results}

Fixed-effects OLS regressions corroborate the impression given by the kernel density estimates and the anecdotal evidence presented above. The results from Table 2 are particularly pronounced for the post-World War II period. Government vote shares drop by close to 4.4 percentage points, while the opposition vote share increases by 3.5 percentage points. This compares to a mean value of $50 \%$ and $47 \%$, respectively. ${ }^{20}$ In contrast, in the pre-World War II period, the vote shares are statistically insignificant and show much smaller coefficients. The same is true when using the full sample.

The differences before and after the mid-20th century are also apparent for our fractionalization measures. Parliamentary fractionalization increases significantly, by more than 6 percentage points in the contemporaneous sample, but it is not affected after financial crises prior to World War II (coefficient not significant). Similarly, we find that the coefficient for the number of parties in parliament is large and significant after World War II, but not before. The point estimate of 1.11 indicates that, on average, more than one additional party entered the legislature in the five-year spell after financial crises since 1950.

The results are strengthened when estimating local projections and controlling for macroeconomic fundamentals, as shown in Figure 5. In the full sample and for the preWorld War II sample, the results show no significant dynamics. The indicators for financial recessions are mostly insignificant (see also the Appendix Tables E1 to E4). However, in the post World War II sample, government vote shares drop significantly after financial recessions and opposition vote shares increase, particularly in years 2 and 3 after the recession start. ${ }^{21}$

With respect to fractionalization, the results are equally pronounced. The two lower

\footnotetext{
${ }^{20}$ The discrepancy in coefficient size between government and opposition vote shares indicates that previously unaligned factions join the opposition in post-crisis periods.

${ }^{21}$ The coefficients indicate that governments saw their vote shares drop by a cumulative $9 \%$ (not percentage points) in the immediate aftermath of financial crises in the post-World War II era. The second panel shows the corresponding result for opposition vote shares, which increase by a total of $11 \%$ in year 2 after the start of the recession and the cumulative effect remains significant with a high coefficient until the five year horizon.
} 
Table 2: Parliamentary variables: post-crisis years vs. normal years
(a) Full sample
(b) Pre-WWII
(c) Post-WWII

\begin{tabular}{|c|c|c|c|}
\hline \multicolumn{4}{|c|}{ Government vote share } \\
\hline Post-crisis & $\begin{array}{l}-2.275 \\
(1.564)\end{array}$ & $\begin{array}{l}-0.133 \\
(1.765)\end{array}$ & $\begin{array}{c}-4.377^{* * *} \\
(1.383)\end{array}$ \\
\hline$R^{2}$ & 0.006 & 0.000 & 0.022 \\
\hline Obs. & 1865 & 636 & 1229 \\
\hline \multicolumn{4}{|c|}{ Opposition vote share } \\
\hline Post-crisis & $\begin{array}{c}1.623 \\
(1.506)\end{array}$ & $\begin{array}{c}-0.456 \\
(1.784)\end{array}$ & $\begin{array}{l}3.523^{* *} \\
(1.434)\end{array}$ \\
\hline$R^{2}$ & 0.003 & 0.000 & 0.013 \\
\hline Obs. & 1865 & 636 & 1229 \\
\hline \multicolumn{4}{|c|}{ Fractionalization of parliament } \\
\hline Post-crisis & $\begin{array}{c}0.0114 \\
(0.0206)\end{array}$ & $\begin{array}{c}0.00790 \\
(0.0139)\end{array}$ & $\begin{array}{c}0.0627^{* *} \\
(0.0227)\end{array}$ \\
\hline$R^{2}$ & 0.001 & 0.001 & 0.029 \\
\hline Obs. & 2241 & 969 & 1272 \\
\hline \multicolumn{4}{|c|}{ No. of parties in parliament } \\
\hline Post-crisis & $\begin{array}{c}0.374 \\
(0.500)\end{array}$ & $\begin{array}{c}0.385 \\
(0.281)\end{array}$ & $\begin{array}{c}1.110^{* * *} \\
(0.342)\end{array}$ \\
\hline$R^{2}$ & 0.002 & 0.004 & 0.026 \\
\hline Obs. & 2241 & 969 & 1272 \\
\hline
\end{tabular}

Notes: This table compares the post-crisis levels of the parliamentary variables to their average levels. The time window for post crisis is five years. Robust standard errors (clustered by country) are shown in parentheses. Table D1 details which crises are included. Regressions controlled for GDP per capita growth rate and CPI inflation rate (not reported). The left panels cover the years 1870-2014, the middle panels 1870-1938, and the right panels 1950-2014. Periods of global war (1914-1918 and 1939-1949) are excluded. *** Significant at .01. ** Significant at .05. * Significant at .1.

panels of Figure 5 show that both the fractionalization and the number of parties in the legislature increase significantly in the aftermath of financial recessions after World War II. Parliamentary fractionalization rises by $1.6 \%$, cumulatively, over a five year horizon, while the increase in the number of parties amounts to almost $10 \%$ in year 5 . As discussed above, the results in this section are also robust when controlling for voter turnout, suffrage, presidential vs. parliamentary systems and for proportional representation vs. first-past-the-post systems (see above for definition and sources). 
Figure 5: Parliamentary variables (local projections): financial crisis recessions

Full sample Pre-WW2 sample Post-WW2 sample
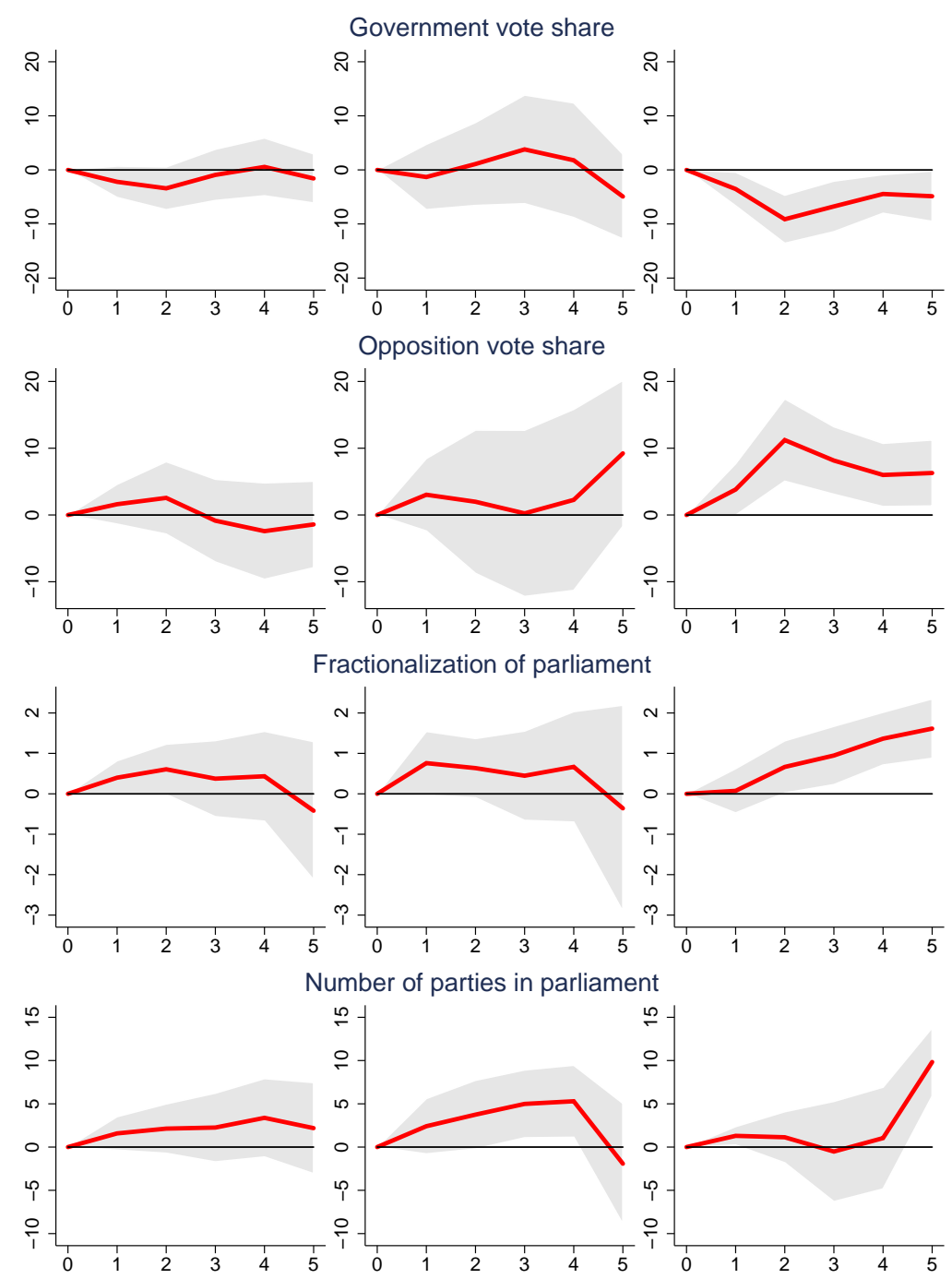

Notes: Each path shows local projections of the cumulative change relative to peak for years $1-5$ of the recession/recovery period. The red line refers to the average path in financial crisis recessions and the shaded region is a $90 \%$ confidence interval. The controls are contemporaneous and 1-year lagged values of the growth rate of GDP per capita and the CPI inflation rate at peak. The left panels cover the years 1870-2014, the middle panels 1870-1938, and the right panels 1950-2014. The periods of global war (1914-1918 and 1939-1949) are excluded. Table D2 shows the recessions included. For the corresponding regression results refer to Appendix Table E1 (government vote share) up through Table E4 (number of parties).

\subsubsection{Polarization, instability, and uncertainty}

What are the consequences of the observed increase in polarization and fractionalization after financial crises? To address this question, we study the links between polarization and 
policy uncertainty and instability. In particular, we want to understand whether political instability increases in years with weaker governments and more fragmented parliaments.

A useful proxy for political stability in the post-crisis period is the number of major government crises per year, defined as "any rapidly developing situation that threatens to bring the downfall of the present regime" by Banks and Wilson (2014). To approximate political instability and uncertainty, we also use a dummy on executive turnover from the Gloemans, Gleditsch, and Chiozza (2009) Archigos dataset. Here a year in which "a new executive leader-spell begins" is coded as 1 , and all other years as zero. ${ }^{22}$ Table 3 displays the results of fixed-effects regressions for the post-World War II sample, in which our results on fragmentation were significant.

The dependent variables are a) government crises and b) executive turnover, and the sample is restricted to a five year window post-crisis as in Mian, Sufi and Trebbi (2014). The regression for government crises uses a standard fixed-effects OLS model (column 1), since there are up to six government crises in a single year. The regressions with executive turnover as dependent variable use a fixed effects logit model (column 2), since turnover is binary, but the results are similar with OLS. Both models include year and country fixed effects.

These exploratory regressions show that the more strongly polarized politics seen after financial crises tend to be associated with more frequent government instability and a higher probability of executive turnover. For instance, a one standard deviation (14.5\%) drop in the government vote share is associated with a 0.34 , or approximately half a standard deviation, increase in the number of severe government crises in post-crisis years, on average.Similarly, a one standard deviation increase in fractionalization (by 0.19) is associated with an increase in government crises by 0.32 . The coefficients for vote shares and fractionalization in column 2 (executive turnover) are also quantitatively and statistically significant. Overall, the evidence uncovered here lends support to the idea that heightened political fractionalization and polarization after financial crises has negative effects, in particular on political stability.

\footnotetext{
${ }^{22}$ Gloemans, Gleditsch, and Chiozza (2009) regard the prime minister as the chief executive in parliamentary systems, and in presidental systems, the president. We exclude executive turnovers that involve foreign imposition, assassinations, ill health, natural death or suicide.
} 
Table 3: Political instability in the post-crisis period

\begin{tabular}{lcc}
\hline & $\begin{array}{c}\text { Major Government crises } \\
\text { (Fixed effects OLS) }\end{array}$ & $\begin{array}{c}\text { Executive turnover } \\
\text { (Fixed effects logit) }\end{array}$ \\
\hline Government vote & $-0.0223^{* *}$ & $-0.103^{* * *}$ \\
$R^{2}$ & $(0.0091)$ & $(0.0291)$ \\
Observations & 0.677 & - \\
Opposition vote & 106 & 106 \\
& $0.0209^{*}$ & $0.0986^{* * *}$ \\
$R^{2}$ & $(0.0101)$ & $(0.0269)$ \\
Observations & 0.673 & - \\
& 101 & 106 \\
Fractionalization & $1.7617^{* *}$ & $7.118^{* * *}$ \\
& $(0.6947)$ & $(2.230)$ \\
$R^{2}$ & 0.586 & - \\
Observations & 106 & 106 \\
No. of parties & $0.0739^{*}$ & $0.290^{* *}$ \\
$R^{2}$ & $(0.0403)$ & $(0.121)$ \\
Observations & 0.549 & - \\
& 106 & 106 \\
\hline \hline
\end{tabular}

\begin{abstract}
Notes: This table regresses two measures of political instability (major government crises per year and a dummy for executive turnover) on our main parliamentary variables. The sample is restricted to post-crisis windows in the post-World War II period. Column 1 shows coefficients of an OLS regression with country and year fixed effects. Column 2 shows coefficients from a fixed effects logit regression. Robust standard errors in parentheses. *** Significant at .01. ** Significant at .05. * Significant at .1.
\end{abstract}

\title{
4.3 People take to the streets
}

The recent turmoil in Europe's troubled southern periphery, particularly Greece and Spain, has shown how a financial crisis can trigger political protest not only at the polls, but also in the streets. In this section, we study the link between crises and social unrest based on our long-run cross-country dataset.

Figure 6 shows the average yearly number of general strikes (light blue columns), violent riots (white columns) and anti-government demonstrations (black columns). The grey columns sum these three components to an aggregate measure of street protests. We also consider the 1919-2012 period, which is the largest, ${ }^{23}$ include our sample of 20 countries and compare five pre-crisis years (left panel) to five post-crisis years (right panel).

\footnotetext{
${ }^{23}$ Domestic conflict event data is available from Banks and Wilson (2014) until 2012.
} 
Figure 6: Street protests

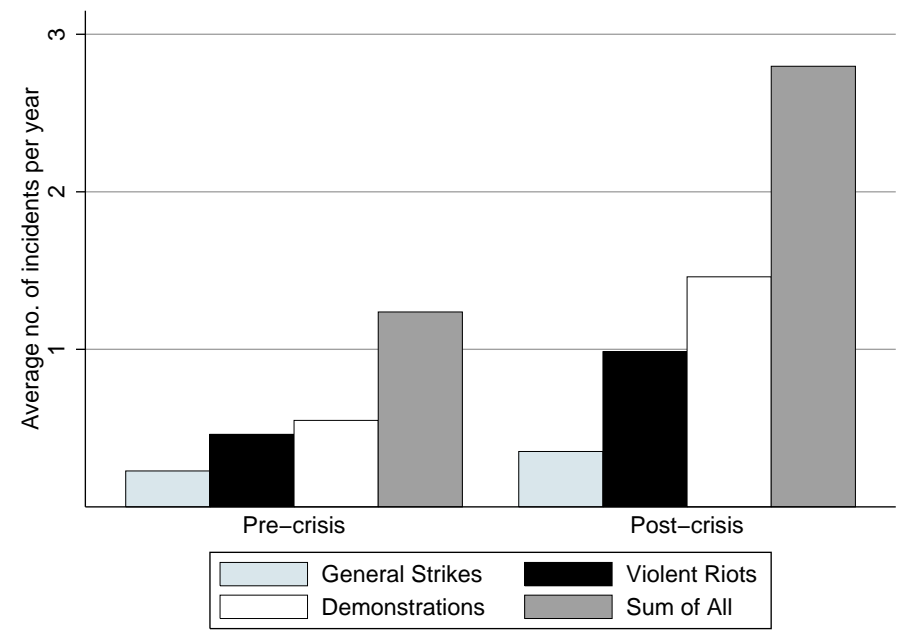

Notes: The figure shows the average number of street protest incidents per year, including the number of general strikes (light blue columns), violent riots (black columns), anti-government demonstrations (white columns) and the sum of the three (grey columns). The left panel refers to pre-crisis averages (five years) and the right-hand side bars to post-crisis averages (five years). Appendix Table D1 shows the crises that are included.

The figure indicates a strong increase in street protests in the crisis aftermath: the average number of incidents more than doubles during financial crises episodes, from about 1.2 events to just under 3 per year, and this difference is statistically significant at the $5 \%$ level. Looking at the different components, the average number of anti-government demonstrations almost triples, the average number of violent riots doubles, and general strikes increase by at least one-third. For demonstrations and violent riots, the mean difference is also statistically significant at the $5 \%$ level.

The fixed effects OLS regressions shown in Table 4 use the "detrended" street protest measures as dependent variables and regresses the cyclical components on a five year post-crisis dummy. The results reinforce the impression of the descriptive picture above. Street protests see a significant increase post-crisis, although the results vary by type of measure and the time sample used. Violent riots increase most notably in crises during the interwar period, but see no significant increase in crises after World War II. The opposite holds true for general strikes, where the post-crisis dummy is not significant before World War II, but significant at the $10 \%$ level thereafter. Anti-government demonstrations generally increase after financial crises, both then and now. 
Table 4: Street protest variables: post-crisis years vs. normal years

\begin{tabular}{lccc} 
& (a)Full sample & (b)Pre-WWII & (c)Post-WWII \\
\hline \hline \multicolumn{4}{c}{ General strikes } \\
\hline Post-crisis & 0.0493 & -0.00338 & $0.107^{*}$ \\
& $(0.0369)$ & $(0.0287)$ & $(0.0537)$ \\
$R^{2}$ & 0.009 & 0.000 & 0.036 \\
Obs. & 1646 & 396 & 1250 \\
\hline \multicolumn{4}{c}{ Violent riots } \\
\hline Post-crisis & $0.102^{* *}$ & $0.197^{* *}$ \\
& $(0.0426)$ & $(0.0872)$ & 0.00734 \\
$R^{2}$ & 0.010 & 0.064 & $0.0571)$ \\
Obs. & 1646 & 396 & 0.000 \\
\hline \multicolumn{5}{c}{ Anti-government demonstrations } \\
\hline Post-crisis & $0.0950^{* * *}$ & $0.120^{*}$ & 1250 \\
& $(0.0319)$ & $(0.0587)$ & $0.150^{* *}$ \\
$R^{2}$ & 0.012 & 0.078 & $0.0679)$ \\
Obs. & 1646 & 396 & 0.019 \\
\hline \multicolumn{5}{c}{ Street protests } \\
\hline Post-crisis & $0.133^{* *}$ & $0.195^{* *}$ & 1250 \\
& $(0.0542)$ & $(0.0877)$ & 0.124 \\
$R^{2}$ & 0.012 & 0.055 & $0.0857)$ \\
Obs. & 1646 & 396 & 1250 \\
\hline \hline
\end{tabular}

Notes: This table compares the post-crisis levels of the number of street protests events per year (\% deviation from trend) to their average level. The time window for post crisis is five years. Robust standard errors (clustered by country) are shown in parentheses. Table D1 shows the crises that are included. Regressions controlled for GDP per capita growth rate and CPI inflation rate (not reported). The left panels cover the years 1919-2012, excluding World War II (1939-1949), the middle panels 1919-1938, and the right panels 1950-2012. *** Significant at .01. ${ }^{* *}$ Significant at .05. * Significant at .1.

The local projections in Figure 7 confirm these findings. We present the results for total street protest incidences, i.e., the combined number of general strikes, violent riots and anti-government demonstrations per year as the dependent variable. The picture looks similar if we use these variables individually. Street protests increase strongly in our full sample of financial crisis spells (left panel), with a cumulative deviation from trend of $20 \%$. The results are more pronounced for the post-World War II sample (right panel), especially when compared to the pre-World War II sample (middle panel). This may be due to the fact that the frequency of street protests was generally high during the 1920s and 1930s. 
Figure 7: Streets protests (local projections): financial crisis recessions (\% dev. from trend)

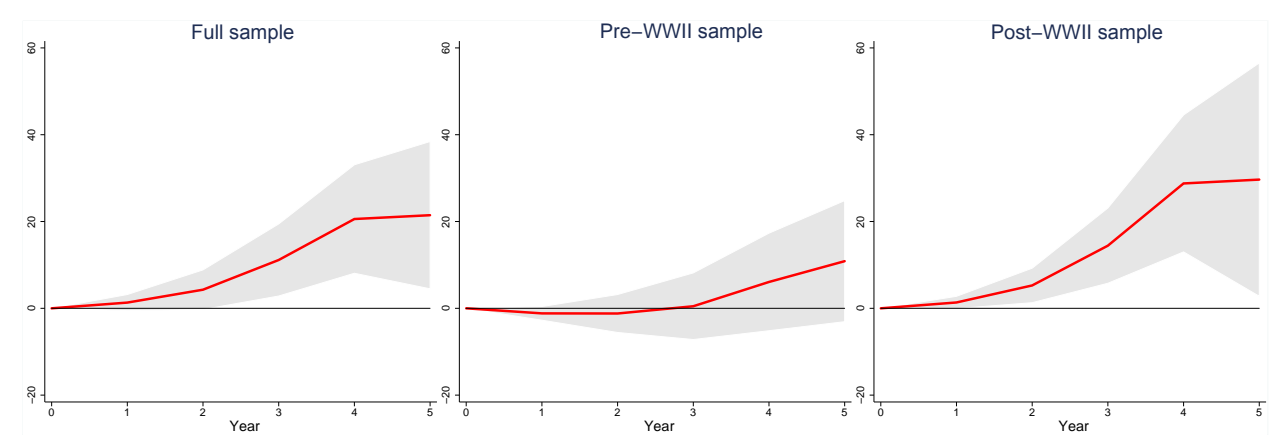

Notes: Each path shows local projections of the cumulative change relative to peak for years $1-5$ of the recession/recovery period. The red line refers to the average path in financial crisis recessions and the shaded region is a $90 \%$ confidence interval. The controls are contemporaneous and 1-year lagged values of the growth rate of GDP per capita and the CPI inflation rate at peak. The left panel covers the years 1919-2014, excluding World War II (1939-1949), the middle panel 1919-1938, and the right panel 1950-2014. Table D2 shows the recessions that are included. The dependent variable is the percentage deviation from trend in the combined number of street protests (general strikes, violent riots and anti-government demonstrations) per year. For the corresponding regression results see Appendix Table E5.

\subsection{How persistent are the effects?}

How long-lasting are the political after-shocks of financial crises? Do the effects fade out, and if so, when? To shed light on this, we extend the time frame of the analysis to a ten year window after the crisis event. Figure 8 displays the post-crisis path of far-right and government vote shares as well as parliamentary fractionalization and the number of parties in parliament over a 10 year horizon.

The graphs demonstrate that the political effects are temporary and diminish over time. 10 years after the crisis, almost all variables are back to their pre-crisis levels.

The top panel shows that the increase in far-right votes is no longer significantly different from zero after year 8 . Also the point estimates decrease strongly from a peak of about $30 \%$ to $40 \%$ in year 5 to about $20 \%$ or less by year 10 . We find similar responses when looking at government vote shares, as shown in the second panel of Figure 8. The point estimates decrease in years 6 to 10 after the crisis and are no longer different from zero in the medium and long run. The degree of political radicalization clearly diminishes over time. Parliamentary fractionalization measures also return to their initial levels over a 10 year horizon. Among all variables, the increase in the number of parties represented 
Figure 8: 10-year local projections: financial crisis recessions

All recessions
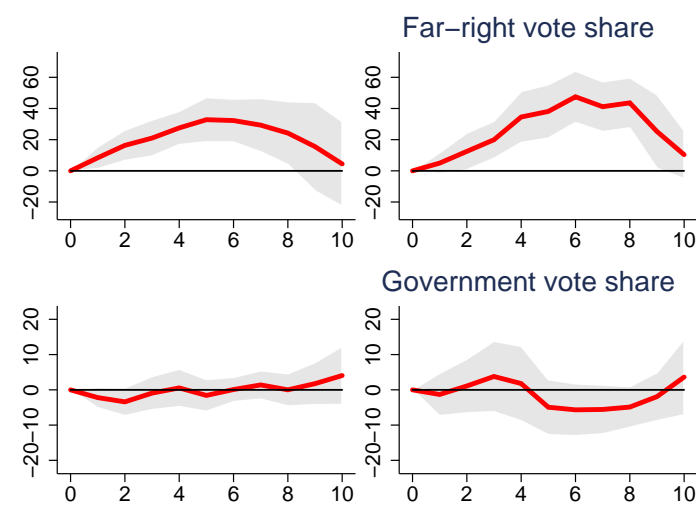

Government vote share

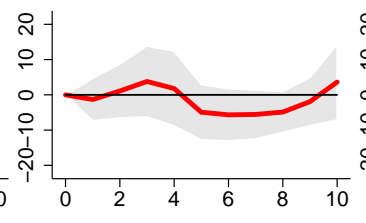

Fractionalization of parliament
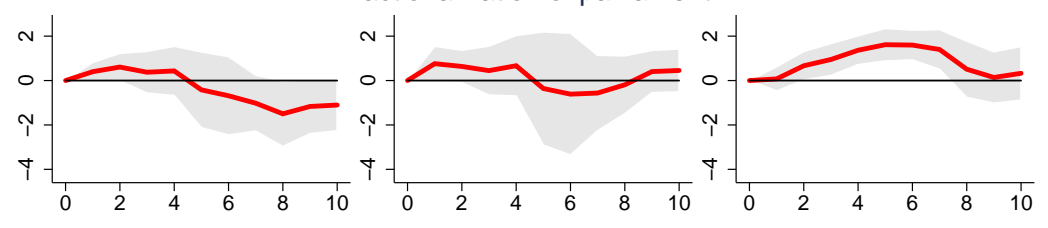

Number of parties in parliament
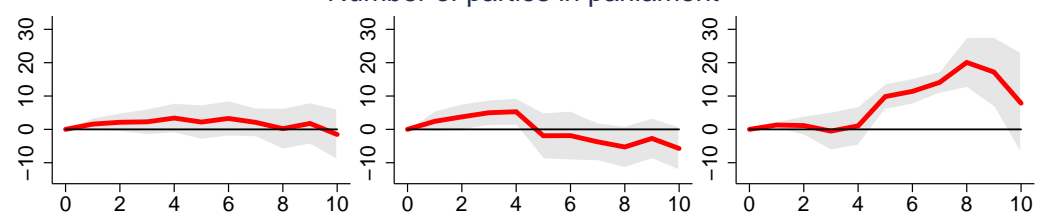

Notes: Each path shows local projections of the cumulative change in the political variables relative to peak for years 1-10 of the recession/recovery period. The red line refers to the average path in financial crisis recessions and the shaded region is a $90 \%$ confidence interval. The controls are contemporaneous and 1-year lagged values of the growth rate of GDP per capita and the CPI inflation rate at peak. Table D2 shows the financial crisis recessions included. Time periods for each variable are the same as in the above local projections of that variable in Section 4. For the corresponding regression results for years 1-5 we again refer to Table 5 (far-right vote share) in the text and to Table E1 (government vote share) up through Table E4 (number of parties) in the appendix. The regression results for years 6-10 are not reported, but are available upon request.

in parliament appears to be the most persistent effect of crises. In the post-World War II sample, it takes a decade before the effects are no longer visible in the data.

To sum up, the political consequences of financial crisis start to fade about 5 years after the beginning of the crisis. While some political after-effects of financial crises are measurable for a decade, the good news from our regressions is that the political upheaval in the wake of financial crises is mostly temporary. 


\section{Normal recessions and non-financial macro disasters}

We have shown that financial crises go hand in hand with substantial radicalization and fragmentation of the political landscape. In this section, we compare the political fall-out from financial crises with other episodes of economic distress. It is by now a well-documented fact that financial crises are typically accompanied by economic recessions. Are the political after-effects of financial crises comparable to the political dynamics in other recessions, or are financial crises special? This is the first question we will address. A sceptic observer might point out that financial crisis recessions tend to be deeper than normal recessions so that the correct benchmark for comparison would be equally severe (non-financial) recessions. A second test is to compare the political aftermath of financial crisis with severe non-financial recessions - sometimes dubbed macro-disasters in the literature.

In the following section we track the trajectory of key indicators of political stability in financial crisis recession, in normal recessions and in deep economic crises that are not associated with a financial crash ("non-financial macro disasters"). We define the latter in Section 2 as (non-financial) recessions that are more severe than the average financial crisis recession, i.e., the annualized percentage fall in GDP per capita exceeds the respective thresholds of $3.35 \%$ (pre-World War II sample) and 2.55\% (post-World War II sample). Financial crisis recessions are all recessions that coincide with a systemic financial crisis. All other recessions are called "normal recessions". Consequently, in the local projections we will subject the economy to three different "treatments": recessions associated with a systemic financial crisis, normal recessions, and other (non-financial) macro disasters.

Table 5 demonstrates that financial crises are different. Financial recessions are followed by a significantly larger increase in far-right votes than either normal recessions or nonfinancial macro-disasters. The F-test rejects the null of equal coefficients at most horizons. The only exception is the interwar period, where substantial increases in far-right votes also occurred in other recessions.

Table 6 shows the coefficients for the three types of downturns for the other political variables. To save space we exclude opposition vote shares and focus on the post-World War II sample where the effects are more precisely estimated. The full set of results can be 
Table 5: Local projections of far-right vote shares

\begin{tabular}{|c|c|c|c|c|c|}
\hline (a) Full sample & Year 1 & Year 2 & Year 3 & Year 4 & Year 5 \\
\hline Financial recession & $\begin{array}{l}8.40^{*} \\
(4.32)\end{array}$ & $\begin{array}{c}16.36^{* *} \\
(5.97)\end{array}$ & $\begin{array}{c}21.04^{* * *} \\
(7.07)\end{array}$ & $\begin{array}{c}27.53^{* * * *} \\
(6.55)\end{array}$ & $\begin{array}{c}32.81^{* * *} \\
(8.71)\end{array}$ \\
\hline Normal recession & $\begin{array}{c}4.86 \\
(3.09)\end{array}$ & $\begin{array}{c}7.06^{* *} \\
(3.12)\end{array}$ & $\begin{array}{c}8.45^{* *} \\
(3.09)\end{array}$ & $\begin{array}{l}5.96^{*} \\
(2.96)\end{array}$ & $\begin{array}{l}7.54^{*} \\
(4.11)\end{array}$ \\
\hline Non-financial macro disaster & $\begin{array}{l}-0.70 \\
(1.51)\end{array}$ & $\begin{array}{l}-1.66 \\
(2.75)\end{array}$ & $\begin{array}{c}1.26 \\
(6.83)\end{array}$ & $\begin{array}{c}0.15 \\
(7.40)\end{array}$ & $\begin{array}{c}11.62 \\
(12.15)\end{array}$ \\
\hline $\mathrm{H}_{0}$ : Financial = normal; $\mathrm{p}$-value & 0.59 & 0.22 & 0.13 & 0.01 & 0.02 \\
\hline $\mathrm{H}_{0}:$ Financial $=$ disaster $; \mathrm{p}$ & 0.05 & 0.01 & 0.05 & 0.00 & 0.15 \\
\hline$R^{2}$ & 0.034 & 0.063 & 0.085 & 0.109 & 0.121 \\
\hline Observations & 1563 & 1543 & 1523 & 1503 & 1483 \\
\hline (b) Pre-WWII sample & Year 1 & Year 2 & Year 3 & Year 4 & Year 5 \\
\hline Financial recession & $\begin{array}{c}4.96 \\
(4.07)\end{array}$ & $\begin{array}{l}12.49^{*} \\
(7.22)\end{array}$ & $\begin{array}{c}19.97^{* *} \\
(7.29)\end{array}$ & $\begin{array}{c}34.54^{* * *} \\
(10.00)\end{array}$ & $\begin{array}{c}38.12^{* * *} \\
(10.47)\end{array}$ \\
\hline Normal recession & $\begin{array}{c}7.92 \\
(6.10)\end{array}$ & $\begin{array}{c}12.69^{* *} \\
(4.68)\end{array}$ & $\begin{array}{c}14.91^{* * * *} \\
(3.61)\end{array}$ & $\begin{array}{c}19.05^{* * * *} \\
(3.66)\end{array}$ & $\begin{array}{c}22.43^{* * *} \\
(3.90)\end{array}$ \\
\hline Non-financial macro disaster & $\begin{array}{l}4.83^{* *} \\
(2.04)\end{array}$ & $\begin{array}{c}9.67^{* * * *} \\
(3.21)\end{array}$ & $\begin{array}{c}15.78^{* * * *} \\
(4.47)\end{array}$ & $\begin{array}{c}22.33^{* * *} \\
(5.98)\end{array}$ & $\begin{array}{c}25.61^{* * * *} \\
(7.00)\end{array}$ \\
\hline $\mathrm{H}_{0}$ : Financial = normal; p-value & 0.69 & 0.98 & 0.55 & 0.14 & 0.14 \\
\hline $\mathrm{H}_{0}$ : Financial = disaster; $\mathrm{p}$-value & 0.99 & 0.71 & 0.61 & 0.25 & 0.28 \\
\hline $\begin{array}{l}R^{2} \\
\text { Observations }\end{array}$ & $\begin{array}{c}0.127 \\
389\end{array}$ & $\begin{array}{c}0.233 \\
389\end{array}$ & $\begin{array}{c}0.348 \\
389\end{array}$ & $\begin{array}{c}0.483 \\
389\end{array}$ & $\begin{array}{c}0.554 \\
389\end{array}$ \\
\hline (c) Post-WWII sample & Year 1 & Year 2 & Year 3 & Year 4 & Year 5 \\
\hline Financial recession & $\begin{array}{l}13.48^{*} \\
(7.69)\end{array}$ & $\begin{array}{c}23.25^{* *} \\
(8.54)\end{array}$ & $\begin{array}{c}26.82^{* *} \\
(10.06)\end{array}$ & $\begin{array}{c}28.11^{* * * *} \\
(6.51)\end{array}$ & $\begin{array}{c}35.64^{* * * *} \\
(6.75)\end{array}$ \\
\hline Normal recession & $\begin{array}{c}5.40 \\
(3.13)\end{array}$ & $\begin{array}{l}7.77^{*} \\
(3.79)\end{array}$ & $\begin{array}{c}10.30^{* *} \\
(4.60)\end{array}$ & $\begin{array}{c}6.82 \\
(4.15)\end{array}$ & $\begin{array}{l}8.58 \\
(5.30)\end{array}$ \\
\hline Non-financial macro disaster & $\begin{array}{l}-0.52 \\
(2.13)\end{array}$ & $\begin{array}{l}-1.49 \\
(4.04)\end{array}$ & $\begin{array}{c}6.02 \\
(13.29)\end{array}$ & $\begin{array}{c}5.21 \\
(13.82)\end{array}$ & $\begin{array}{c}28.93 \\
(24.83)\end{array}$ \\
\hline $\mathrm{H}_{0}:$ Financial = normal; p-value & 0.35 & 0.10 & 0.10 & 0.01 & 0.00 \\
\hline $\mathrm{H}_{0}$ : Financial = disaster; $\mathrm{p}$-value & 0.09 & 0.01 & 0.19 & 0.14 & 0.80 \\
\hline$R^{2}$ & 0.054 & 0.100 & 0.135 & 0.161 & 0.181 \\
\hline Observations & 1174 & 1154 & 1134 & 1114 & 1094 \\
\hline
\end{tabular}

Notes: *** Significant at .01. ** Significant at .05. * Significant at .1. Robust standard errors (clustered by country) in parentheses. Results correspond to local projections of cumulative change in 100 times the logged variable relative to peak for years $1-5$ of the financial recession (first row), normal recession (second row), and non-financial macro disaster (third row). The top panel (a) covers the years 1919-2014, with World War II years (1939-1949) being excluded, the middle panel (b) covers the years 1919-1938, and the bottom panel (c) covers the years 1950-2014. Financial $=$ normal (disaster) tests the null that coefficients for each type of recession are the same for the intercept terms in the first and second (third) rows. In each case the p-value of the test is provided. The controls are contemporaneous and 1-year lagged values of the growth rate of GDP per capita and the CPI inflation rate at peak (coefficients not reported). See text. 
found in Appendix Tables E1 up through E5. We also refer the reader to these tables for the $R^{2}$ and other test statistics.

What are the main insights from Table 6? First, in normal recessions, the political system remains relatively stable. Government vote shares and measures of parliamentary fragmentation do not see notable shifts. Similarly, street protests barely increase in the course of normal recessions. Second, a key difference between financial recessions and severe macro disasters is that support for the government increases during non-financial macro-disasters, but falls significantly in financial crisis recessions. Put differently, in non-financial disasters people rally behind the government. In financial crises, support for the government drops sharply. The bottom panel of Table 6 mirrors this finding: street protests rise strongly after financial crises, but stay flat in non-financial macro disasters. Parliamentary fragmentation increases after non-financial macro disasters, but the effects are estimated imprecisely and remain insignificant at all horizons.

To provide further robustness checks, we applied stricter thresholds to define macrodisasters. For instance, we only coded the most severe non-financial recessions (top 25\% and top $10 \%$ of the distribution) as macro disasters, or used the harshest non-financial recession in each country. None of this affected our core finding that the political fall-out from financial crises is different and, for the most part, more severe.

How can we account for the fact that financial crises provoke severe political disruptions and other economic crises do not? A first potential explanation could be that non-financial crises are perceived as "excusable" events, triggered by large exogenous shocks such as oil prices, natural catastrophes, or wars. In contrast, financial crises may be perceived as an endogenous and "inexcusable" types of crisis that are the result of policy failures, moral hazard and favoritism. In other words, the electorate may blame politics for the occurrence of financial crises because the perception is that the crash could have been avoided.

A second explanation is that financial crises typically involve bailouts for the financial sector and these are highly unpopular (e.g., Broz 2005). Consequently, financial crises may result in more political dissatisfaction than non-financial crises. ${ }^{24}$

A third explanation is that financial crises have social repercussions that are not

\footnotetext{
${ }^{24}$ These explanations relate to Giuliano and Spilimbergo (2014) who find a higher propensity to distrust political institutions among individuals growing up during recessions than among individuals without such experiences.
} 
Table 6: Local projections of political variables, post-World War II sample

\begin{tabular}{|c|c|c|c|c|c|}
\hline & Year 1 & Year 2 & Year 3 & Year 4 & Year 5 \\
\hline \multicolumn{6}{|c|}{ Government vote share } \\
\hline Financial recession & $\begin{array}{c}-3.53^{*} \\
(1.90)\end{array}$ & $\begin{array}{c}-9.12^{* * *} \\
(2.72)\end{array}$ & $\begin{array}{c}-6.75^{* *} \\
(2.85)\end{array}$ & $\begin{array}{l}-4.45^{*} \\
(2.18)\end{array}$ & $\begin{array}{l}-4.86 \\
(2.84)\end{array}$ \\
\hline Normal recession & $\begin{array}{l}-0.78 \\
(1.56)\end{array}$ & $\begin{array}{l}-0.47 \\
(1.57)\end{array}$ & $\begin{array}{l}-0.26 \\
(1.48)\end{array}$ & $\begin{array}{c}0.24 \\
(1.18)\end{array}$ & $\begin{array}{l}-0.23 \\
(1.44)\end{array}$ \\
\hline Non-financial macro disaster & $\begin{array}{l}-1.10 \\
(1.53)\end{array}$ & $\begin{array}{c}0.31 \\
(2.69)\end{array}$ & $\begin{array}{l}9.43^{*} \\
(5.28)\end{array}$ & $\begin{array}{c}3.27^{* *} \\
(1.52)\end{array}$ & $\begin{array}{c}0.19 \\
(6.66)\end{array}$ \\
\hline $\mathrm{H}_{0}$ : Financial $=$ normal; $\mathrm{p}$-value & 0.34 & 0.02 & 0.02 & 0.10 & 0.20 \\
\hline $\mathrm{H}_{0}$ : Financial = disaster; p-value & 0.38 & 0.05 & 0.01 & 0.01 & 0.48 \\
\hline \multicolumn{6}{|c|}{ Fractionalization of parliament } \\
\hline Financial recession & $\begin{array}{c}0.07 \\
(0.33)\end{array}$ & $\begin{array}{c}0.67 \\
(0.39)\end{array}$ & $\begin{array}{c}0.95^{* *} \\
(0.44)\end{array}$ & $\begin{array}{c}1.36^{* * *} \\
(0.40)\end{array}$ & $\begin{array}{c}1.61^{* * *} \\
(0.45)\end{array}$ \\
\hline Normal recession & $\begin{array}{l}-0.10 \\
(0.17)\end{array}$ & $\begin{array}{l}-0.40 \\
(0.26)\end{array}$ & $\begin{array}{c}0.64 \\
(0.74)\end{array}$ & $\begin{array}{c}0.49 \\
(0.78)\end{array}$ & $\begin{array}{c}0.10 \\
(0.78)\end{array}$ \\
\hline Non-financial macro disaster & $\begin{array}{l}-0.29 \\
(0.38)\end{array}$ & $\begin{array}{l}-0.90 \\
(0.53)\end{array}$ & $\begin{array}{c}2.19 \\
(3.74)\end{array}$ & $\begin{array}{c}2.59 \\
(3.65)\end{array}$ & $\begin{array}{c}1.73 \\
(4.17)\end{array}$ \\
\hline $\mathrm{H}_{0}$ : Financial $=$ normal; p-value & 0.63 & 0.01 & 0.71 & 0.32 & 0.10 \\
\hline $\mathrm{H}_{0}$ : Financial = disaster; $\mathrm{p}$-value & 0.44 & 0.01 & 0.74 & 0.73 & 0.98 \\
\hline \multicolumn{6}{|c|}{ Number of parties in parliament } \\
\hline Financial recession & $\begin{array}{l}1.30^{*} \\
(0.65)\end{array}$ & $\begin{array}{c}1.13 \\
(1.80)\end{array}$ & $\begin{array}{l}-0.52 \\
(3.53)\end{array}$ & $\begin{array}{c}1.04 \\
(3.58)\end{array}$ & $\begin{array}{c}9.84^{* * *} \\
(2.41)\end{array}$ \\
\hline Normal recession & $\begin{array}{c}1.58 \\
(1.11)\end{array}$ & $\begin{array}{c}1.80 \\
(1.53)\end{array}$ & $\begin{array}{c}2.80 \\
(1.77)\end{array}$ & $\begin{array}{c}1.83 \\
(1.41)\end{array}$ & $\begin{array}{c}2.37 \\
(1.53)\end{array}$ \\
\hline Non-financial macro disaster & $\begin{array}{l}-0.10 \\
(1.21)\end{array}$ & $\begin{array}{c}5.15 \\
(7.96)\end{array}$ & $\begin{array}{c}8.31 \\
(9.54)\end{array}$ & $\begin{array}{l}11.96 \\
(8.02)\end{array}$ & $\begin{array}{l}12.63 \\
(7.90)\end{array}$ \\
\hline $\mathrm{H}_{0}$ : Financial $=$ normal; p-value & 0.74 & 0.76 & 0.42 & 0.83 & 0.01 \\
\hline $\mathrm{H}_{0}$ : Financial = disaster; $\mathrm{p}$-value & 0.28 & 0.63 & 0.40 & 0.20 & 0.73 \\
\hline \multicolumn{6}{|c|}{ Street protests (\% deviation from trend) } \\
\hline Financial recession & $\begin{array}{c}1.35 \\
(0.86)\end{array}$ & $\begin{array}{l}5.27^{* *} \\
(2.41)\end{array}$ & $\begin{array}{c}14.44^{* *} \\
(5.27)\end{array}$ & $\begin{array}{c}28.77^{* * *} \\
(9.59)\end{array}$ & $\begin{array}{l}29.66^{*} \\
(16.34)\end{array}$ \\
\hline Normal recession & $\begin{array}{c}2.06^{* *} \\
(0.73)\end{array}$ & $\begin{array}{c}2.32 \\
(1.44)\end{array}$ & $\begin{array}{c}0.43 \\
(2.11)\end{array}$ & $\begin{array}{l}-0.29 \\
(2.47)\end{array}$ & $\begin{array}{l}-1.84 \\
(2.70)\end{array}$ \\
\hline Non-financial macro disaster & $\begin{array}{c}3.74 \\
(2.33)\end{array}$ & $\begin{array}{c}7.57 \\
(5.43)\end{array}$ & $\begin{array}{c}6.26 \\
(6.40)\end{array}$ & $\begin{array}{c}4.35 \\
(7.02)\end{array}$ & $\begin{array}{c}3.86 \\
(10.08)\end{array}$ \\
\hline $\mathrm{H}_{0}$ : Financial $=$ normal; p-value & 0.58 & 0.39 & 0.04 & 0.01 & 0.08 \\
\hline $\mathrm{H}_{0}$ : Financial = disaster; $\mathrm{p}$-value & 0.40 & 0.74 & 0.39 & 0.08 & 0.19 \\
\hline
\end{tabular}

Notes: ${ }^{* * *}$ Significant at .01. ${ }^{* *}$ Significant at $.05 .{ }^{*}$ Significant at .1. Robust standard errors (clustered by country) in parentheses. Results correspond to local projections of cumulative change in 100 times the logged variable relative to peak for years 1-5 of the financial recession (first row), normal recession (second row), and non-financial macro disaster (third row). The data cover the years 1950-2014. Financial $=$ normal $($ disaster) tests the null that coefficients for each type of recession are the same for the intercept terms in the first and second (third) rows. In each case the p-value of the test is provided. The controls are contemporaneous and 1-year lagged values of the growth rate of GDP per capita and the CPI inflation rate at peak (coefficients not reported). See text. 
observable after non-financial recessions. For example, it is possible that the disputes between creditors and debtors are uglier in the wake of financial crises, be it internally or internationally (e.g., Halac and Schmukler 2004; Mian, Sufi, and Trebbi 2014). Similarly, it is possible that inequality rises more strongly in the aftermath of financial crises, but less so in other crisis types (e.g., Atkinson and Morelli 2011; Bordo and Meissner 2011). Exploring these questions is beyond the scope of this paper, but will be addressed in future research.

\section{Conclusion}

This paper studies the political aftermath of financial crises with a historical perspective. The evidence we uncover shows that financial crises put a strain on modern democracies. The typical political reaction is as follows: votes for far-right parties increase strongly, government majorities shrink, the fractionalization of parliaments rises and the overall number of parties represented in parliament jumps. These developments likely hinder crisis resolution and contribute to political gridlock. The resulting policy uncertainty may contribute to the much debated slow economic recoveries from financial crises.

Financial crises are politically disruptive, even when compared to other economic crises. Indeed, we find no (or only slight) political effects of normal recessions and different responses in severe crises not involving a financial crash. In the latter, right wing votes do not increase as strongly and people rally behind the government. In the light of modern history, political radicalization, declining government majorities and increasing street protests appear to be the hallmark of financial crises. As a consequence, regulators and central bankers carry a big responsibility for political stability when overseeing financial markets. Preventing financial crises also means reducing the probability of a political disaster. 


\section{References}

[1] Ahlquist, John S., Ben Ansell, and Johannes Lindvall. 2014. Between Depression and Devaluation: Leadership Turnover in Hard Times. Unpublished Manuscript.

[2] Alesina, Alberto, and Guido Tabellini. 1990. A Positive Theory of Fiscal Deficits and Government Debt. Review of Economic Studies 57(3): 403-14.

[3] Alt, James, and David Lassen. 2006. Transparency, Political Polarization, and Political Budget Cycles in OECD Countries. American Journal of Political Science 5(3): 530550 .

[4] Atkinson, Anthony B., and Salvatore Morelli. 2011. Economic Crises and Inequality. UNDP-HDRO Occasional Papers No. 2011/6.

[5] Azzimotti, Marina. 2011. Barriers to Investment in Polarized Societies. American Economic Review, 101(5): 2182-2204.

[6] Azzimotti, Marina. 2015. Partisan Conflict and Private Investment, mimeo.

[7] Azzimonti, Marina, and Matthew Talbert. 2014. Polarized Business Cycles. Journal of Monetary Economics: forthcoming.

[8] Bachmann, Ruediger, Steffen Elstner, and Eric R. Sims. 2013. Uncertainty and Economic Activity: Evidence from Business Survey Data. American Economic Journal: Macroeconomics 5(2): 217-49.

[9] Baker, Scott R., Nicholas Bloom, and Steven J. Davis. 2013. Measuring Economic Policy Uncertainty, mimeo.

[10] Baker, Scott, Nicholas Bloom, Brandice Canes-Wrone, Steven Davis, and Jonathan Rodden. 2014. Why Has US Policy Uncertainty Risen Since 1960? American Economic Review 104(5): 56-60.

[11] Banks, Arthur S., and Kenneth Wilson. 2014. Cross National Time-Series Data Archive. Jerusalem: Databanks International.

[12] Barro, Robert J.. 2006. Rare Disasters and Asset Markets in the Twentieth Century. The Quarter Journal of Economics 121(3): 823-866.

[13] Barro, Robert J., and José F. Ursúa. 2008. Macroeconomic Crises since 1870. Brookings Papers on Economic Activity 39(1): 255-350.

[14] Barro, Robert J., and José F. Ursúa. 2011. Rare Macroeconomic Disasters. NBER Working Paper No. 17328.

[15] Beck, Thorsten, George Clarke, Alberto Groff, Philip Keefer, and Patrick Walsh. 2001. New Tools in Comparative Political Economy: The Database of Political Institutions. World Bank Economic Review 15(1): 165-176.

[16] Bernhard, William, and David Leblang. 2008. Cabinet Collapses and Currency Crashes. Political Research Quarterly 61(3): 517-531.

[17] Betz, Hans-Georg. 1994. Radical Right Wing Populism in Western Europe. New York: St. Martin's Press. 
[18] Bloom, Nick. 2009. The Impact of Uncertainty Shocks. Econometrica 77(3): 623-685.

[19] Bloom, Nick, Stephen Bond, and John Van Reenen. 2007. Uncertainty and Investment Dynamics. Review of Economic Studies 74(2): 391-415.

[20] Bloom, Nicholas, Max Floetotto, Nir Jaimovich, Itay Saporta, and Stephen Terry. 2012. Really Uncertain Business Cycles, NBER Working Paper No. 18245.

[21] Bordo, Michael D., Barry Eichengreen, Daniela Klingebiel, and Maria Soledad Martinez-Peria. 2001. Is the Crisis Problem Growing More Severe? Economic Policy 16(32): $53-83$.

[22] Bordo, Michael D., and Christopher M. Meissner. 2011. Do Financial Crises Always Raise Inequality? Some Evidence from History, mimeo.

[23] Broz, J. Lawrence. 2005. Congressional Politics of International Financial Rescues. American Journal of Political Science 49(3): 479-496.

[24] Bry, Gerhard, and Charlotte Boschan. 1971. Cyclical Analysis of Time Series: Selected Procedures and Computer Programs. New York: NBER.

[25] Cappocia, Giovanni. 2001. Defending Democracy: Reactions to Extremism in Interwar Europe. European Journal of Political Research 39(2): 431-460.

[26] Chwieroth, Jeffrey M., and Andrew Walter. 2013. From Low to Great Expectations: Banking Crises and Partisan Survival Over the Long Run. Available at SSRN: http://ssrn.com/abstract $=2258980$

[27] Crespo-Tenorio, Adriana, Nathan M. Jensen, and Guillermo Rosas. 2012. Political Liabilities: Surviving Banking Crises. Comparative Political Studies, forthcoming.

[28] de Bromhead, Alan, Barry Eichengreen, and Kevin H. O'Rourke. 2012. Right Wing Political Extremism in the Great Depression. Discussion Papers in Economic and Social History, Number 95, University of Oxford.

[29] Döring, Holger, and Philip Manow. 2012. Parliament and Government Composition Database: An Infrastructure For Empirical Information on Parties, Elections and Governments in Modern Democracies. Bremen, Version 12/10 - 15 October 2012.

[30] Frieden, Jeffrey. 2015. The Political Economy of Adjustment and Rebalancing. Journal of International Money and Finance, 52: 4-14.

[31] Goemans, Henk, Kristian Skrede Gleditsch, and Giacomo Chiozza. 2009. Introducing Archigos: A Data Set of Political Leaders. Journal of Peace Research 46(2): 269-183.

[32] Giuliano, Paola, and Antonio Spilimbergo. 2014. Growing Up in a Recession. Review of Economic Studies 81(2): 787-817.

[33] Haggard, Stephan. 2000. The Political Economy of the Asian Financial Crisis, Washington, DC, Institute for International Economics.

[34] Halac, Marina C., and Sergio L. Schmukler. 2004. Distributional Effects of Crises: The Financial Channel World Bank Policy Research Working Paper No. 3173.

[35] Henisz, Witold. 2000. The Institutional Environment for Economic Growth. Economics and Politics 12(1): 1-31. 
[36] Hodrick, Robert, and Edward Prescott. 1997. Post-War U.S. Business Cycles: An Empirical Investigation. Journal of Money, Credit, and Banking 29(1): 1-16.

[37] Horrowitz, Donald L.. 2003. Electroal Systems: A Primer for Decision Makers. Journal of Democracy 14(4): 115-127.

[38] Ignazi, Piero. 2003. Extreme Right Parties in Western Europe. Oxford: University Press.

[39] Jordà, Òscar. 2005. Estimation and Inference of Impulse Responses by Local Projections. American Economic Review 95(1): 161-182.

[40] Jordà, Òscar, Moritz Schularick, and Alan M. Taylor. 2011. Financial Crises, Credit Booms and External Imbalances: 140 Years of Lessons. IMF Economic Review 59(2): 340-78.

[41] Jordà, Òscar, Moritz Schularick, and Alan M. Taylor. 2013. When Credit Bites Back. Journal of Money, Credit, and Banking 45(s2): 3-28.

[42] Jordà, Òscar, Moritz Schularick, and Alan M. Taylor. 2014a. Sovereigns versus Banks: Credit, Crises, and Consequences. NBER Working Paper No. 19506.

[43] Jordà, Òscar, Moritz Schularick, and Alan M. Taylor. 2014b. The Great Mortgaging: Housing Finance, Crises, and Business Cycles. NBER Working Paper No. 20501.

[44] Kose, M. Ayhan, Prakash Loungani, and Marco E. Terrones. 2013. The Great Diversion of Policies. World Economic Outlook, April, International Monetary Fund.

[45] Laeven, Luc, and Fabian Valencia. 2008. Systemic Banking Crises: A New Database. IMF Working Paper 08/224.

[46] Laeven, Luc, and Fabian Valencia. 2012. Systemic Banking Crises Database: An Update. IMF Working Paper 12/163.

[47] Lo, Stepahnie and Kenneth Rogoff. 2015. Secular Stagnation, Debt Overhang and Other Rationales for Sluggish Growth, Six Years On. BIS Working Paper No. 482.

[48] Lijphart, Arend. 1994. Electoral Systems and Party Systems: A Study of Twenty-seven Democracies, 1945-1990. Oxford: Oxford University Press.

[49] Lindqvist, Erik, and Robert Östling. 2010. Political Polarization and the Size of Government. American Political Science Review 104(03): 543-565.

[50] MacIntyre, Andrew. 2002. Institutions and Investors: The Politics of the Financial Crisis in Southeast Asia. International Organization 55(1): 81-122.

[51] Mackie, Thomas T., and Richard Rose. 1974. The International Almanac of Electoral History. London: Macmillan.

[52] McLaren Carstairs, Andrew. 1980. A Short History of Electoral Systems in Western Europe. New York: Routledge.

[53] McCarthy, Nolan, Keith Poole, and Howard Rosenthal. 2008. Polarized America: The Dance of Ideology and Unequal Riches. Cambridge: MIT Press. 
[54] Mian, Atif, Amir Sufi, and Francesco Trebbi. 2014. Resolving Debt Overhang: Political Constraints in the Aftermath of Financial Crises. American Economic Journal: Macroeconomics 6(2): 1-28.

[55] Minkenberg, Michael. 2001. The Radical Right in Public Office: Agenda Setting and Policy Effects. West European Politics 24(4): 1-21.

[56] Minkenberg, Michael. 2008. The Radical Right in Europe. An Overview. Gütersloh: Verlag Bertelsmann Stiftung.

[57] Minkenberg, Michael, and Pascal Perrineau. 2007. The Radical Right in the European Elections 2004. International Political Science Review 28(1): 29-55.

[58] Mudde, Cas. 2000. The Ideology of the Extreme Right. Manchester: Manchester University Press.

[59] Mudde, Cas. 2005. Racist Extremism in Central and Eastern Europe. London: Routledge.

[60] Mudde, Cas. 2007. Populist Radical Right Parties in Europe. Cambridge: Cambridge University Press.

[61] Nohlen, Dieter. 2005. Elections in the Americas: A Data Handbook: Volume I: North America, Central America, and the Caribbean. Oxford: OUP.

[62] Nohlen, Dieter, and Philip Stöver. 2010. Elections in Europe: A Data Handbook. Baden-Baden: Nomos.

[63] Passarelli, Francesco, and Guido Tabellini. 2013. Emotions and Political Unrest. CESifo Working Paper 4165.

[64] Perri, Fabrizio, and Joe Steinberg. 2012. Inequality and Redistribution During the Great Recession. Economic Policy Paper 12-1. Federal Reserve Bank of Minneapolis.

[65] Ponticelli, Jacopo, and Hans-Joachim Voth. 2011. Austerity and Anarchy: Budget Cuts and Social Unrest in Europe, 1919-2008. CEPR Discussion Paper 8513.

[66] Reinhart, Carmen M., and Kenneth S. Rogoff. 2009a. The Aftermath of Financial Crises. American Economic Review 99(2): 466-472.

[67] Reinhart, Carmen M., and Kenneth S. Rogoff. 2009b. This Time Is Different: Eight Centuries of Financial Folly. Princeton, New Jersey: Princeton University Press.

[68] Reinhart, Carmen M., and Kenneth S. Rogoff. 2014. Recovery from Financial Crises: Evidence from 100 Episodes. American Economic Review 104(5): 50-55.

[69] Rokkan, Stein. 1967. Geography, Religion and Social Class: Crosscutting Cleavages in Norwegian Policies. In S.M. Lipset and S. Rokkan (eds.): Party Systems and Voter Alignments. New York: Free Press: 367-444.

[70] Romer, Christina D., and David Romer. 1989. Does Monetary Policy Matter? A Test in the Spirit of Friedman and Schwartz. In NBER Macroeconomics Annual 1989 edited by Olivier Jean Blanchard and Stanley Fischer. Cambridge: MIT Press, 121-184.

[71] Sartori, Giovanni. 1976. Parties and Party Systems. Cambridge: Cambridge University Press. 
[72] Schularick, Moritz, and Alan M. Taylor. 2012. Credit Booms Gone Bust: Monetary Policy, Leverage Cycles, and Financial Crises, 1870-2008. American Economic Review 102(2): 1029-61.

[73] Stjernquist, Nils. 1966. Sweden: Stability or Deadlock? In R.A. Dahl (ed.): Political Oppositions in Western Democracies. New Haven: Yale University Press: 116-146. 


\section{Appendix A Variables and summary statistics}

Table A1: Main variables: description and sources

\begin{tabular}{|c|c|c|}
\hline Variable & Description & Sources \\
\hline Government vote share & $\begin{array}{l}\text { Vote share of governing party or coalition } \\
\text { in the most recent general elections to the } \\
\text { national parliament (lower chamber) }\end{array}$ & $\begin{array}{l}\text { Mackie and Rose (1974), Nohlen and } \\
\text { Stöver (2010), Döring and Manow (2012) } \\
\text { and country-specific sources listed in Ap- } \\
\text { pendix B }\end{array}$ \\
\hline Opposition vote share & $\begin{array}{l}\text { Combined vote share of all opposition par- } \\
\text { ties, excluding independents, in the most } \\
\text { recent general elections to the national par- } \\
\text { liament (lower chamber) }\end{array}$ & $\begin{array}{l}\text { Mackie and Rose (1974), Nohlen and } \\
\text { Stöver (2010), Döring and Manow (2012) } \\
\text { and country-specific sources listed in Ap- } \\
\text { pendix B }\end{array}$ \\
\hline Far-right/ far-left vote share & $\begin{array}{l}\text { Combined vote share of all far-right (far- } \\
\text { left) political parties with more than } 0.1 \% \\
\text { of total votes in the most recent general } \\
\text { elections to the national parliament (lower } \\
\text { chamber) }\end{array}$ & $\begin{array}{l}\text { Bertelsmann Foundation (2009), Betz } \\
\text { (1994), Capoccia (2012), de Bromhead, } \\
\text { Eichengreen, and O'Rourke (2012), } \\
\text { Minkenberg, (2001, 2008), Mudde (2000, } \\
\text { 2005, 2007) and country-specific sources } \\
\text { listed in Appendix B }\end{array}$ \\
\hline Fractionalization & $\begin{array}{l}\text { The probability that two representatives } \\
\text { picked at random from among the parties } \\
\text { in the legislature will be of different parties; } \\
\text { range: }[0 ; 1]\end{array}$ & $\begin{array}{l}\text { Mackie and Rose (1974), Nohlen and } \\
\text { Stöver (2010), Döring and Manow (2012) } \\
\text { and country-specific sources listed in Ap- } \\
\text { pendix B }\end{array}$ \\
\hline No. of parties & $\begin{array}{l}\text { The number of parties elected into the leg- } \\
\text { islative branch in the most recent general } \\
\text { election to the national parliament (lower } \\
\text { chamber) }\end{array}$ & $\begin{array}{l}\text { Mackie and Rose (1974), Nohlen and } \\
\text { Stöver (2010), Döring and Manow (2012) } \\
\text { and country-specific sources listed in Ap- } \\
\text { pendix B }\end{array}$ \\
\hline Violent riots & $\begin{array}{l}\text { Any violent demonstration or clash of more } \\
\text { than } 100 \text { citizens involving the use of phys- } \\
\text { ical force. }\end{array}$ & Banks and Wilson (2014) \\
\hline General strikes & $\begin{array}{l}\text { Any strike of } 1,000 \text { or more industrial or } \\
\text { service workers that involves more than } \\
\text { one employer and is aimed at national gov- } \\
\text { ernment policies or authority }\end{array}$ & Banks and Wilson (2014) \\
\hline Demonstrations & $\begin{array}{l}\text { Any peaceful public gathering of at least } \\
100 \text { people for the purpose of voicing oppo- } \\
\text { sition to government policies or authority, } \\
\text { excluding demonstrations of a distinctly } \\
\text { anti-foreign nature }\end{array}$ & Banks and Wilson (2014) \\
\hline Street protests & $\begin{array}{l}\text { The sum of violent riots, general strikes, } \\
\text { and demonstrations per year }\end{array}$ & Banks and Wilson (2014) \\
\hline Executive turnover & $\begin{array}{l}1 \text { indicates year with a new leadership; } 0 \\
\text { indicates year with no changes in effective } \\
\text { executive }\end{array}$ & $\begin{array}{l}\text { Beck et al. (2001), Goemans, Gleditsch, } \\
\text { and Chiozza (2009) }\end{array}$ \\
\hline Government crises & $\begin{array}{l}\text { Any rapidly developing situation that } \\
\text { threatens to bring the downfall of the } \\
\text { present regime - excluding situations of re- } \\
\text { volt aimed at such an overthrow }\end{array}$ & Banks and Wilson (2014) \\
\hline Financial crises & $\begin{array}{l}\text { Events during which a country's banking } \\
\text { sector experiences bank runs, sharp in- } \\
\text { creases in default rates accompanied by } \\
\text { large losses of capital that result in public } \\
\text { intervention, bankruptcy, or forced merger } \\
\text { of financial institutions }\end{array}$ & $\begin{array}{l}\text { Bordo et al. (2001), Reinhart and Rogoff } \\
\text { (2009b), Laeven and Valencia (2008, 2012), } \\
\text { Jordà, Schularick, and Taylor (2013) }\end{array}$ \\
\hline Recessions & $\begin{array}{l}\text { Financial recessions: financial crisis within } \\
\pm 2 \text { years around peak. Normal re- } \\
\text { cessions: all non-financial peaks. Non- } \\
\text { financial macro disasters: normal reces- } \\
\text { sions with yearly real p.c. GDP percentage } \\
\text { loss }>\text { average loss in financial recessions }\end{array}$ & $\begin{array}{l}\text { Algrorithm from Bry and Boschan (1971), } \\
\text { crisis dating based on Jordà, Schularick, } \\
\text { and Taylor (2013) and their sources }\end{array}$ \\
\hline GDP & Growth rate of real GDP per capita & $\begin{array}{l}\text { Jordà, Schularick, and Taylor (2013) and } \\
\text { their sources }\end{array}$ \\
\hline Inflation & CPI inflation rate & $\begin{array}{l}\text { Jordà, Schularick, and Taylor (2013) and } \\
\text { their sources }\end{array}$ \\
\hline
\end{tabular}


Table A2: Summary statistics

\begin{tabular}{lcclcc}
\hline Variable & Obs. & Mean & Std.Dev. & Min. & Max. \\
\hline Far-right vote share & 1754 & 5.53 & 14.6 & 0.00 & 99.8 \\
Far-left vote share & 1754 & 5.56 & 7.05 & 0.00 & 34.4 \\
Government vote share & 2078 & 50.7 & 14.5 & 12.3 & 100 \\
Opposition vote share & 2078 & 46.1 & 14.6 & 0.00 & 84.1 \\
Fractionalization of parliament & 2510 & 0.63 & 0.18 & 0.00 & 0.89 \\
No. of parties in parliament & 2495 & 6.26 & 3.51 & 1.00 & 21.0 \\
No. of general strikes & 1727 & 0.22 & 0.72 & 0.00 & 8.00 \\
No. of violent riots & 1727 & 0.81 & 2.80 & 0.00 & 55.0 \\
No. of anti-government demonstrations & 1727 & 0.82 & 2.99 & 0.00 & 60.0 \\
No. of street protest incidents & 1727 & 1.85 & 5.42 & 0.00 & 85.0 \\
No. of major government crises & 1727 & 0.36 & 0.82 & 0.00 & 6.00 \\
Executive turnover dummy & 2400 & 0.28 & 0.45 & 0.00 & 1.00 \\
Financial crises dummy & 2900 & 0.04 & 0.19 & 0.00 & 1.00 \\
Financial recession dummy & 2900 & 0.03 & 0.17 & 0.00 & 1.00 \\
Normal recession dummy & 2900 & 0.12 & 0.33 & 0.00 & 1.00 \\
Non-financial macro disaster dummy & 2900 & 0.02 & 0.15 & 0.00 & 1.00 \\
& & & & &
\end{tabular}

Notes: Summary statistics refer to the raw data collected for all 20 countries and all years from 1870 to 2014, including non-democratic spells and periods of global war (1914-1918 and 1939-1949). Generally not considered in the empirical analysis of political variables are Austria and Ireland prior to World War I, and Australia prior to 1901 (no independent states). Finland prior to 1917, as an autonomous part of the Russian Empire, is considered. 


\section{Appendix B Coding of elections and parliamentary variables}

This section lists the sources used to code our archive of election results (vote shares) and parliamentary composition from 1870-2014. The bibliographical details of main sources are shown in the reference list above, while country-specific references are shown in full below.

\section{B.1 Sources of election dates, results and parliamentary composition}

The election data come from the following three main sources:

- D/M: Döring and Manow (2012)

- M/R: Mackie and Rose (1974)

- N/S: Nohlen and Stöver (2010)

Detailed election data sources per country:

Australia: Elections from 1901-2013: D/M. - Austria: 1919-1930: M/R. 1945-2013: D/M. - Belgium: 1870.1-1939: M/R. 1946-2014: D/M. - Canada: 1872-1940: M/R. 1945-2011: D/M. - Denmark: 1872-1873: Skov, Kaare. 1999. Demokratiets Danmarkshistorie - Gennem 150 år. Kopenhagen: Aschenhoug. 1876-1882: N/S. 1884-1943: M/R. 1945-2011: D/M. - Finland: 1907-1924: M/R. 1927-2011: D/M. - France: 1871-1898: N/S. 1902-1936: M/R. 1945-2012: D/M. - Germany: 1871-1933.1: M/R. 1933.2-1938: Jung, Otmar. 1998. Wahlen und Abstimmungen im Dritten Reich 1933-1938. In: Eckhard Jesse and Konrad Löw (ed.): Wahlen in Deutschland (Berlin: Duncker \& Humblot 1998): 69-98. 1949-2013: D/M. - Greece: 1873-1964: N/S. 1974-2012.2: D/M. - Ireland: 1918-1943: M/R. 1944-2011: D/M. - Italy: 1870-1892: N/S. 1895-1921: M/R. 1924-1934: Salvatorelli, Luigi, and Giovanni Mira. 1945. Storia del Fascismo - Italia dal 1919 al 1945. Roma: Edizioni di Novissima. 1946-2013: D/M. - Japan: 1890-1937: Scalapino, Robert. 1968. Elections and Political Modernization in Prewar Japan. In: Robert Ward (ed.): Political Development in Modern Japan (Princeton: Princeton University Press 1968): 249-292. 1942: Drea, Edward. 1979. The 1942 Japanese General Election: Political Mobilization in Wartime Japan. Chicago: Paragon. 1946-2014: D/M. - Netherlands: 1888-1937: M/R. 1946-2012: D/M. - Norway: 1870.2-1879: N/S. 1882-1936: M/R. 1945-2013: D/M. Portugal: 1871-1973: N/S. 1975-2011: D/M. - Spain: 1871-1936: N/S. 1977-2011: D/M. - Sweden: 1887.1-1940: M/R. 1944-2014: D/M. - Switzerland: 1872-1893: Gruner, Erich. 1978. Die Wahlen in den Schweizerischen Nationalrat 1848-1919: Vol 1. Bern: Francke.. 1896-1917: M/R; 1919-2011: D/M. - United Kingdom: 1874-1880: Craig, Frederick Walter Scott. 1989. British Electoral Facts: 1832-1987. Dartmouth: Parliamentary Research Services. 1885-1935: M/R. 1945-2010: D/M. - United States: 1870-1918: Dubin, Michael J. 1998. United States Congressional Elections, 1788-1997: The Official Results of the Elections of the 1st through 105th Congresses. Jefferson: McFarland. 1920-2014: Office of the Clerk of the U.S. House of Representatives. 2014. Election Statistics. Availabe at www.history.house.gov/institution/election-statistics/election-statistics/.

An overview of all elections in our 20-country sample spanning the years from 18702014 is provided in the table below. Altogether, we identified 751 elections, but we could not find sufficient data for 32 of these (in round brackets), so the final sample of coded elections includes 719 events. 
Table B1: Parliamentary elections 1870-2014

\begin{tabular}{|c|c|c|c|c|c|c|c|c|c|c|c|c|c|c|c|c|c|c|c|}
\hline AUS & AUT & BEL & CAN & $\mathrm{CHE}$ & DEU & DNK & ESP & FIN & FRA & GBR & GRC & IRL & ITA & JPN & NLD & NOR & PRT & SWE & USA \\
\hline 1901 & 1919 & $1870^{*}$ & 1872 & 1872 & [1871] & {$[1872]$} & $(1871)$ & $(1872)$ & 1871 & 1874 & 1873 & 1918 & $(1870)$ & [1890] & $(1871)$ & $\left(1870^{*}\right)$ & )[1871] & $(1872)$ & 1870 \\
\hline 1903 & 1920 & 1872 & 1874 & 1875 & {$[1874]$} & [1873] & $(1872)$ & (1877) & 1876 & 1880 & 1875 & 1921 & 1874 & [1892] & (1873) & (1873) & {$[1874]$} & (1875) & 1872 \\
\hline 1906 & 1923 & 1874 & 1878 & 1878 & {$[1877]$} & {$[1876]$} & 1873 & (1882) & 1877 & 1885 & 1879 & 1922 & 1876 & {$\left[1894^{*}\right]$} & $(1875)$ & (1876) & {$[1878]$} & (1878) & 1874 \\
\hline 1910 & 1927 & 1876 & 1882 & 1881 & {$[1878]$} & {$[1879]$} & {$[1876]$} & (1885) & 1881 & 1886 & 1881 & 1923 & 1880 & {$[1898 *]$} & (1877) & (1879) & {$[1879]$} & (1881) & 1876 \\
\hline 1913 & 1930 & 1878 & 1887 & 1884 & {$[1881]$} & {$\left[1881^{*}\right]$} & [ [1879] & (1888) & 1885 & 1892 & 1885 & $1927^{*}$ & 1882 & {$[1902]$} & $(1879)$ & {$[1882]$} & [1881] & $(1884)$ & 1878 \\
\hline 1914 & 1945 & 1880 & 1891 & 1887 & {$[1884]$} & {$[1882]$} & [1881] & (1891) & 1889 & 1895 & 1890 & 1932 & 1886 & [1903] & (1881) & 1885 & {$[1884]$} & {$\left[1887^{*}\right]$} & 1880 \\
\hline 1917 & 1949 & 1882 & 1896 & 1890 & {$[1887]$} & [1884] & [1884] & (1894) & 1893 & 1900 & 1892 & 1933 & 1890 & [1904] & (1883) & 1888 & {$[1887]$} & [1890] & 1882 \\
\hline 1919 & 1953 & 1884 & 1900 & 1893 & {$[1890]$} & [1887] & [1886] & (1900) & 1898 & 1906 & 1895 & 1937 & 1892 & [1908] & (1884) & 1891 & [1889] & [1893] & 1884 \\
\hline 1922 & 1956 & 1886 & 1904 & 1896 & [1893] & {$[1890]$} & [1891] & (1901) & 1902 & $1910^{*}$ & 1899 & 1938 & 1895 & [1912] & (1886) & 1894 & [1890] & {$[1896]$} & 1886 \\
\hline 1925 & 1959 & 1888 & 1908 & 1899 & [1898] & [1892] & [1893] & (1905) & 1906 & 1918 & 1902 & 1943 & 1897 & [1915] & (1887) & 1897 & [1892] & [1899] & 1888 \\
\hline 1928 & 1962 & 1890 & 1911 & 1902 & [1903] & [1895] & [1896] & [1907] & 1910 & 1922 & 1905 & 1944 & 1900 & [1917] & 1888 & 1900 & {$[1894]$} & {$[1902]$} & 1890 \\
\hline 1929 & 1966 & 1892 & 1917 & 1905 & {$[1907]$} & [1898] & [1898] & [1908] & 1914 & 1923 & 1906 & 1948 & 1904 & [1920] & 1891 & 1903 & [1895] & [1905] & 1892 \\
\hline 1931 & 1970 & 1894 & 1921 & 1908 & [1912] & 1901 & [1901] & [1909] & 1919 & 1924 & $1910^{*}$ & 1951 & 1909 & [1924] & 1894 & 1906 & [1897] & [1908] & 1894 \\
\hline 1934 & 1971 & 1896 & 1925 & 1911 & 1919 & 1903 & [1903] & [1910] & 1924 & 1929 & 1912 & 1954 & 1913 & [1928] & 1897 & 1909 & [1899] & [1911] & 1896 \\
\hline 1937 & 1975 & 1898 & 1926 & 1914 & 1920 & 1906 & [1905] & [1911] & 1928 & 1931 & $1915^{*}$ & 1957 & 1919 & [1930] & 1901 & 1912 & [1900] & {$[1914]$} & 1898 \\
\hline 1943 & 1979 & 1900 & 1930 & 1917 & $1924^{*}$ & 1909 & [1907] & [1913] & 1932 & 1935 & 1920 & 1961 & 1921 & [1932] & 1905 & 1915 & [1901] & 1917 & 1900 \\
\hline 1946 & 1983 & 1902 & 1935 & 1919 & 1928 & 1910 & [1910] & [1916] & 1936 & 1945 & 1923 & 1965 & [1924] & [1936] & 1909 & 1918 & [1905] & 1920 & 1902 \\
\hline 1949 & 1986 & 1904 & 1940 & 1922 & 1930 & 1913 & [1914] & [1917] & 1945 & 1950 & 1926 & 1969 & [1929] & [1937] & 1913 & 1921 & {$\left[1906^{*}\right.$} & ] 1921 & 1904 \\
\hline 1951 & 1990 & 1906 & 1945 & 1925 & {$[1932 *]$} & 1915 & [1916] & 1919 & $1946^{*}$ & 1951 & 1928 & 1973 & [1934] & {$[1942]$} & 1917 & 1924 & [1908] & 1924 & 1906 \\
\hline 1954 & 1994 & 1908 & 1949 & 1928 & {$\left[1933^{*}\right]$} & 1918 & [1918] & 1922 & 1951 & 1955 & 1932 & 1977 & 1946 & 1946 & 1918 & 1927 & [1910] & 1928 & 1908 \\
\hline 1955 & 1995 & 1910 & 1953 & 1931 & {$[1936]$} & $1920^{*}$ & [1919] & 1924 & 1956 & 1959 & 1933 & 1981 & 1948 & 1947 & 1922 & 1930 & 1911 & 1932 & 1910 \\
\hline 1958 & 1999 & 1912 & 1957 & 1935 & [1938] & 1924 & [1920] & 1927 & 1958 & 1964 & 1935 & $1982^{*}$ & 1953 & 1949 & 1925 & 1933 & 1915 & 1936 & 1912 \\
\hline 1961 & 2002 & 1914 & 1958 & 1939 & 1949 & 1926 & [1922] & 1929 & 1962 & 1966 & 1936 & 1987 & 1958 & 1952 & 1929 & 1936 & 1918 & 1940 & 1914 \\
\hline 1963 & 2006 & 1919 & 1962 & 1943 & 1953 & 1929 & 1931 & 1930 & 1967 & 1970 & 1946 & 1989 & 1963 & 1953 & 1933 & 1945 & 1919 & 1944 & 1916 \\
\hline 1966 & 2008 & 1921 & 1963 & 1947 & 1957 & 1932 & 1933 & 1933 & 1968 & $1974^{*}$ & 1950 & 1992 & 1968 & 1955 & 1937 & 1949 & 1921 & 1948 & 1918 \\
\hline 1969 & 2013 & 1925 & 1965 & 1951 & 1961 & 1935 & 1936 & 1936 & 1973 & 1979 & 1951 & 1997 & 1972 & 1958 & 1946 & 1953 & 1922 & 1952 & 1920 \\
\hline 1972 & & 1929 & 1968 & 1955 & 1965 & 1939 & 1977 & 1939 & 1978 & 1983 & 1952 & 2002 & 1976 & 1960 & 1948 & 1957 & 1925 & 1956 & 1922 \\
\hline 1975 & & 1932 & 1972 & 1959 & 1969 & 1943 & 1979 & 1945 & 1981 & 1987 & 1956 & 2007 & 1979 & 1963 & 1952 & 1961 & [1934] & 1958 & 1924 \\
\hline 1977 & & 1936 & 1974 & 1963 & 1972 & 1945 & 1982 & 1948 & 1986 & 1992 & 1958 & 2011 & 1983 & 1967 & 1956 & 1965 & [1938] & 1960 & 1926 \\
\hline 1980 & & 1939 & 1979 & 1967 & 1976 & 1947 & 1986 & 1951 & 1988 & 1997 & 1961 & & 1987 & 1969 & 1959 & 1969 & [1942] & 1964 & 1928 \\
\hline 1983 & & 1946 & 1980 & 1971 & 1980 & 1950 & 1989 & 1954 & 1993 & 2001 & 1963 & & 1992 & 1971 & 1963 & 1973 & [1945] & 1968 & 1930 \\
\hline 1984 & & 1949 & 1984 & 1975 & 1983 & $1953^{*}$ & 1992 & 1958 & 1997 & 2005 & 1964 & & 1994 & 1972 & 1967 & 1977 & [1949] & 1970 & 1932 \\
\hline 1987 & & 1950 & 1988 & 1979 & 1987 & 1957 & 1996 & 1962 & 2002 & 2010 & 1974 & & 1996 & 1976 & 1971 & 1981 & [1953] & 1973 & 1934 \\
\hline 1990 & & 1954 & 1993 & 1983 & 1990 & 1960 & 2000 & 1966 & 2007 & & 1977 & & 2001 & 1979 & 1972 & 1985 & [1957] & 1976 & 1936 \\
\hline 1993 & & 1958 & 1997 & 1987 & 1994 & 1964 & 2003 & 1970 & 2012 & & 1981 & & 2006 & 1980 & 1977 & 1989 & [1961] & 1979 & 1938 \\
\hline 1996 & & 1961 & 2000 & 1991 & 1998 & 1966 & 2008 & 1972 & & & 1985 & & 2008 & 1983 & 1982 & 1993 & [1965] & 1982 & 1940 \\
\hline 1998 & & 1965 & 2004 & 1995 & 2002 & 1968 & 2011 & 1975 & & & $1989^{*}$ & & 2013 & 1986 & 1986 & 1997 & [1969] & 1985 & 1942 \\
\hline 2001 & & 1966 & 2006 & 1999 & 2005 & 1971 & & 1979 & & & 1990 & & & 1990 & 1989 & 2001 & [1973] & 1988 & 1944 \\
\hline 2004 & & 1968 & 2008 & 2003 & 2009 & 1973 & & 1983 & & & 1993 & & & 1993 & 1994 & 2005 & 1975 & 1991 & 1946 \\
\hline 2007 & & 1971 & 2011 & 2007 & 2013 & 1975 & & 1987 & & & 1996 & & & 1996 & 1998 & 2009 & 1976 & 1994 & 1948 \\
\hline 2010 & & 1974 & & 2011 & & 1977 & & 1991 & & & 2000 & & & 2000 & 2002 & 2013 & 1979 & 1998 & 1950 \\
\hline \multirow[t]{32}{*}{2013} & & 1977 & & & & 1979 & & 1995 & & & 2004 & & & 2003 & 2003 & & 1980 & 2002 & 1952 \\
\hline & & 1978 & & & & 1981 & & 1999 & & & 2007 & & & 2005 & 2006 & & 1983 & 2006 & 1954 \\
\hline & & 1981 & & & & 1984 & & 2003 & & & 2009 & & & 2009 & 2010 & & 1985 & 2010 & 1956 \\
\hline & & 1985 & & & & 1987 & & 2007 & & & $2012 *$ & & & 2012 & 2012 & & 1987 & 2014 & 1958 \\
\hline & & 1987 & & & & 1988 & & 2011 & & & & & & 2014 & & & 1991 & & 1960 \\
\hline & & 1991 & & & & 1990 & & & & & & & & & & & 1995 & & 1962 \\
\hline & & 1995 & & & & 1994 & & & & & & & & & & & 1999 & & 1964 \\
\hline & & 1999 & & & & 1998 & & & & & & & & & & & 2002 & & 1966 \\
\hline & & 2003 & & & & 2001 & & & & & & & & & & & 2005 & & 1968 \\
\hline & & 2007 & & & & 2005 & & & & & & & & & & & 2009 & & 1970 \\
\hline & & 2010 & & & & 2007 & & & & & & & & & & & 2011 & & 1972 \\
\hline & & 2014 & & & & 2011 & & & & & & & & & & & & & 1974 \\
\hline & & & & & & & & & & & & & & & & & & & 1976 \\
\hline & & & & & & & & & & & & & & & & & & & 1978 \\
\hline & & & & & & & & & & & & & & & & & & & 1980 \\
\hline & & & & & & & & & & & & & & & & & & & 1982 \\
\hline & & & & & & & & & & & & & & & & & & & 1984 \\
\hline & & & & & & & & & & & & & & & & & & & 1986 \\
\hline & & & & & & & & & & & & & & & & & & & 1988 \\
\hline & & & & & & & & & & & & & & & & & & & 1990 \\
\hline & & & & & & & & & & & & & & & & & & & 1992 \\
\hline & & & & & & & & & & & & & & & & & & & 1994 \\
\hline & & & & & & & & & & & & & & & & & & & 1996 \\
\hline & & & & & & & & & & & & & & & & & & & 1998 \\
\hline & & & & & & & & & & & & & & & & & & & 2000 \\
\hline & & & & & & & & & & & & & & & & & & & 2002 \\
\hline & & & & & & & & & & & & & & & & & & & 2004 \\
\hline & & & & & & & & & & & & & & & & & & & 2006 \\
\hline & & & & & & & & & & & & & & & & & & & 08 \\
\hline & & & & & & & & & & & & & & & & & & & 10 \\
\hline & & & & & & & & & & & & & & & & & & & 2012 \\
\hline & & & & & & & & & & & & & & & & & & & 14 \\
\hline
\end{tabular}

Notes: ( ) = no data available [ ] = monarchy/dictatorship $*=$ two elections in that year.

The table provides a chronology of elections from $1870-2014$ by country. We include all general elections to the national parliament, but not sub-national or presidential elections. In the case of a bicameral legislative, we only consider results from the lower legislative chamber. This means that we focus on the following results: AUS: House of Representatives (lower house); AUT: National Council (lower house); BEL: Chamber of Representatives (lower house); CAN: House of Commons (lower house); CHE: National Council (lower house); DEU: Bundestag (until 1945 Reichstag) (unicameral); DNK: Folketing (until 1953 lower house, since then unicameral); ESP: Congress of Deputies (lower house); FIN: Eduskunta (unicameral); FRA: National Assembly (until 1946 Chamber of Deputies) (lower house); GBR: House of Commons (lower house); GRC: Hellenic Parliament (unicameral, bicameral from 19271935); IRL: Dáil Éireann (lower house); ITA: Chamber of Deputies (lower house); JPN: House of Representatives (lower house). NLD: Tweede Kamer (lower house); NOR: Storting (unicameral); PRT: Assembly of the Republic (unicameral, bicameral from 1915-1925); SWE: Riksdag (unicameral); USA: House of Representatives (lower house). 


\section{B.2 Coding of far-right and far-left parties}

This section lists the sources used to classify parties as far-right or far-left in the period from 1919-2014. For the interwar period (1919-1938) we follow the classification in de Bromhead, Eichengreen and O'Rourke (2012) and their main source Capoccia (2001), unless otherwise stated. All remaining sources for our post-World War II classification by country are listed below. The coding result with a full list of far-left and far-right parties is shown in Table B2.

Australia: Davis, Rex, and Robert Stimpson. 1998. Disillusionment and Disenchantment at the Fringe: Explaining the Geography of the One Nation Party Vote at the Queensland Election. People and Place (6)3: 69-82. - Gouttman, Rodney. 2001. Pernicious Vision: Challenge from within Australia's Extreme Right. Australian Journal of Jewish Studies 15: 46-63. - Grant, Bligh. 1997. Pauline Hanson. One Nation and Australian Politics. University of New England Press. - Leach, Michael, Geoff Stokes, and Ian Ward. 2000. The Rise and Fall of One Nation. University of Queensland Press. - Austria: Carter, Elisabeth. 2001. The Extreme Right in Austria. An Overview. EREPS. - Carter, Elisabeth. 2005. The Extreme Right in Western Europe. Manchester, New York: Manchester University Press. - Howard, Marc Morjé. 2001. Can Populism Be Suppressed in a Democracy? Austria, Germany, and the European Union. East European Politics and Societies (15)1: 18-32. - McGann, Anthony, and Herbert Kitschelt. 2005. The Radical Right in The Alps: Evolution of Support for the Swiss SVP and Austrian FPÖ. Party Politics 11(29): 147-171.

- Belgium: Art, David. 2008. The Organizational Origins of the Contemporary Radical Right: The Case of Belgium. Comparative Politics 40(4): 421-440. - Craeybeckx, Jan, Els Witte, and Alain Meynen. 2010. Political History of Belgium: From 1830 Onwards. VUB University Press. - Swyngedouw, Mark. 2009. Country Report Belgium. In: Bertelsmann Stiftung (ed.): Strategies for Combating Right-Wing Extremism in Europe (Gütersloh: Verlag Bertelsmann-Stiftung 2009): 59-80. - Canada: Barrett, Stanley. 1989. The Far Right in Canada. In: C.E.S. Franks (ed.): Dissent and the State (Toronto: University of Toronto Press 1989): 224-246. Oxford University Press: 224-246. - Communist Party of Canada (1982). Canada's Party of Socialism. Toronto: Progress Books. - Parent, Richard A., and James O. Ellis III. 2014. Right-Wing Extremism in Canada. TSAS Working Paper Series No. 14-03. - Ross, Jeffrey Ian. 1992. Contemporary Radical Right-Wing Violence in Canada: A Quantitative Analysis. Terrorism and Political Violence 4(3): 72-101. Denmark: Jungar, Ann-Cathrine, and Anders Ravik Jupskas. 2014. Populist Radical Right Parties in the Nordic Region: A New and Distinct Party Family? Scandinavian Political Studies 37(3): 215-238. - Meret, Susi. 2009. Country Report Denmark. In: Bertelsmann Stiftung (ed.): Strategies for Combating Right-Wing extremism in Europe (Gütersloh: Verlag Bertelsmann-Stiftung 2009): 81-126. - Rydgren, Jens. 2004. Explaining the Emergence of Radical Right-Wing Populist Parties: The Case of Denmark. West European Politics 27(3): 474-502. - Finland: For the interwar years we deviate from de Bromhead, Eichengreen and O'Rourke (2012) in that we do not code the Finnish "National Coalition" as far-right but rather as centre-right (Lane and Ersson 2008, p. 260, table 8.7). While the party was in a one-time electoral alliance with the far-right "Patriotic People's Movement" (1933 elections), we can distinguish between the two and count the "Patriotic People's Movement's" vote share separately. Other sources include Arter, David. 2010. The Breakthrough of Another West European Populist Radical Right Party? The Case of the True Finns. Government and Opposition 45(4): 484-504. - Jungar, Ann-Cathrine, and Anders Ravik Jupskas. 2014. Populist Radical Right Parties in the Nordic Region: A New and Distinct Party Family? Scandinavian Political Studies 37(3): 215-238. Nordensvard, Johan, and Markus Ketola. 2014. Nationalist Reframing of the Finnish 
and Swedish Welfare States - The Nexus of Nationalism and Social Policy in Far-right Populist Parties. Social Policy \& Administration (49)3: 356-375. - France: Camus, Jean-Yves. 2009. Country Report France. In: Bertelsmann Stiftung (ed.): Strategies for Combating Right-Wing Extremism in Europe (Gütersloh: Verlag Bertelsmann-Stiftung 2009): 127-178. - Davies, Peter. 1999. The National Front in France: Ideology, Discourse and Power. New York: Routledge. - Marcus, Jonathan. 1995. The National Front and French Politics. London: Macmillan. - Shields, James. 2007. The Extreme Right in France: From Pétain to Le Pen. New York: Routledge. - Simmons, Harvey. 1996. The French National Front: The Extremist Challenge to Democracy. Boulder: Westview Press. - Germany: Bulmer, Simon. 2014. Germany and the Eurozone Crisis: Between Hegemony and Domestic Politics. West European Politics 37(6): 1244-1263. - Michael, George, and Michael Minkenberg. 2007. A Continuum for Responding to the Extreme Right: A Comparison between the United States and Germany. Studies in Conflict \& Terrorism 30(12): 1109-1123. - Schellenberg, Britta. 2009. Country Report Germany. In: Bertelsmann Stiftung (ed.): Strategies for Combating Right-Wing Extremism in Europe. (Gütersloh: Verlag Bertelsmann-Stiftung 2009): 179-248. Stöss, Richard. 1991. Politics Against Democracy: Extreme Right in West Germany (German Studies Series). Oxford: Berg Publishers. - Greece: Davies, Peter, and Derek Lynch. 2002. The Routledge Companion to Fascism and the Far Right. London: Routledge. - Ellinas, Antonis. 2013. The Rise of Golden Dawn: The New Face of the Far Right in Greece. South European Society and Politics (18)4: 543-565. - Georgiadou, Vassiliki. 2013. Right-Wing Populism and Extremism: The Rapid Rise of "Golden Dawn" in Crisis-Ridden Greece. In: Ralf Melzer and Sebastian Serafin (ed.): Right-Wing Extremism in Europe - Country Analyses, Counter-Strategies and Labor-Market Oriented Exit Strategies (Berlin: Friedrich Ebert Stiftung 2013): 75-101. - March, Luke. 2008. Contemporary Far Left Parties in Europe - From Marxism to the Mainstream? Berlin: International Policy Analysis, FriedrichEbert-Stiftung, Division for International Dialogue. - Stavrakakis, Yannis, and Giorgos Katsambekis. 2014. Left-Wing Populism in the European Periphery: the Case of SYRIZA. Journal of Political Ideologies (19)2: 119-142. - Ireland: -Maillot, Agnès. 2010. Sinn Féin's Approach to the EU: Still More 'Critical' than 'Engaged'? In: Katy Hayward and Marcy C. Murphy (ed.): The Europeanization of Party Politics in Ireland, North and South (New York: Routledge 2010): 143-158. - Murphy, Marcy C., and Katy Hayward. 2010. Party Politics and the EU in Ireland, North and South. In: Katy Hayward and Marcy C. Murphy (ed.): The Europeanization of Party Politics in Ireland, North and South (New York: Routledge 2010): 1-12. - O'Malley, Eoin. 2008. Why is there no Radical Right Party in Ireland? West European Politics (31: 5): 960-977. - Italy: Caciagli, Mario. 1988. The Movimento Sociale Italiano-Destra Nazionale and Neo-Fascism in Italy. West European Politics 11(2): 19-33. - Ignazi, Piero. 2005. Legitimation and Evolution on the Italian Right Wing: Social and Ideological Repositioning of Alleanza Nazionale and the Lega Nord. South European Society and Politics (10)2: 333-349. - Mammone, Andrea. 2009. The Eternal Return? Faux Populism and Contemporarization of Neo-Fascism across Britain, France and Italy. Journal of Contemporary European Studies (17)2: 171-192. Turner, Eric. 2013. The 5 Star Movement and Its Discontents: A Tale of Blogging, Comedy, Electoral Success and Tensions. Interface 5(2): 178-212. - Wetzel, Juliane. 2009. Country Report Italy. In: Bertelsmann Stiftung (ed.): Strategies for Combating Right-Wing Extremism in Europe (Gütersloh: Verlag Bertelsmann-Stiftung 2009): 327-374. - Japan: Berton, Peter. 2000. The Japanese Communist Party and Its Transformations. Japanese Policy Research Institute Working Paper No. 67. - Inoguchi, Takashi. 2014. Japan in 2013: Abenomics and Abegeopolitics. Asian Survey 54(1): 101-112. - Xu Hui Shen, Simon. 
2014. Special Issue Introduction: Domestic Politics in Japan and Sino-Japanese Relations. East Asia 31(1): 1-4. - Netherlands: Donselaar, Jaap von, and Willem Wageneer. 2009. Country Report The Netherlands. In: Bertelsmann Stiftung (ed.): Strategies for Combating Right-Wing Extremism in Europe (Gütersloh: Verlag Bertelsmann-Stiftung 2009): 375-424. - Pauwels, Teun. 2014. Populism in Western Europe: Comparing Belgium, Germany and The Netherlands. New York: Routledge. - Van Gent, Wouter, Elmar Jansen, and Joost Smits. 2014. Right-wing Radical Populism in City and Suburbs: An Electoral Geography of the Partij Voor de Vrijheid in the Netherlands. Urban Studies (51)9: 1775-1794. - Van Heerden, Sjoerdje, Sarah de Lange, Wouter van der Brug, and Meindert Fennema. 2014. The Immigration and Integration Debate in the Netherlands: Discursive and Programmatic Reactions to the Rise of Anti-Immigration Parties. Journal of Ethnic and Migration Studies 40(1): 119-136. - Norway: Jungar, Ann-Cathrine, and Anders Ravik Jupskas. 2014. Populist Radical Right Parties in the Nordic Region: A New and Distinct Party Family? Scandinavian Political Studies 37(3): 215-238. Luke, March. 2008. Contemporary Far Left Parties in Europe. Berlin: Friedrich-Ebert-Stiftung. - Roren, Pal, and John Todd. 2014. We the People? Political Populism in the UK and Norway. NMBU Journal of Life Science 4(1): 23-30. - Widfeldt, Anders. 2014. Extreme Right Parties in Scandinavia. New York: Routledge. - Portugal: Art, David. 2011. Memory Politics in Western Europe: The Extreme Right in Europe. Göttingen: Vandenhoeck \& Ruprecht. - Claire, Annesley. 2005. A Political And Economic Dictionary Of Western Europe. New York: Routledge. - Marchi, Ricardo. 2012. The Portuguese Radical Right in the Democratic Period. In: Andrea Mammone, Emmanuel Godin, and Brian Jenkins (ed.): Mapping the Extreme Right in Contemporary Europe: From Local to Transnational (London: Routledge 2012): 150-172 - Monteiro, Manuel, Paulo Portas, Jaime Nogueira Pinto, Adriano Moreira, António Lobo Xavier, António Marques Bessa. 1994. Viva Portugal - Uma Nova Ideia da Europa. Lisbon: Europa América. - Spain: For the interwar years we deviate from de Bromhead, Eichengreen and O'Rourke (2012) in that we we classify only the Spanish "Falange" as far-right but not the broader, more moderate right-wing alliance "Bloque Nacional" (Blinkhorn 2013, p. 56). Other sources include Benedetto, Giacomo, and Lucia Quaglia. 2007. The Comparative Politics of Communist Euroscepticism in France, Italy and Spain. Party Politics 13(4): 478-499. - HernandezCarr, Aitor. 2012. Right-Wing Extremism in Spain: An Approaching Breakthrough? Available at Extremis Project: extremisproject.org/2012/08/272 - Ramiro-Fernández. 2004. Electoral Competition, Organizational Constraints and Party Change: the Communist Party of Spain (PCE) and United Left (IU), 1986-2000. Journal of Communist Studies and Transition Politics 20(2): 1-29. - Sweden: For the interwar years we deviate from de Bromhead, Eichengreen and O'Rourke (2012) in that we added the anti-semitic "National League of Sweden" to the list of far-right parties (Lodenius and Larsson 1994, p. 106. Further sources are Hellström, Anders, Tom Nilsson, and Pauline Stoltz. 2012. Nationalism vs. Nationalism: The Challenge of the Sweden Democrats in the Swedish Public Debate. Government and Opposition 47(2): 186-205. Lööw, Heléne. 2009. Country Report The Netherlands. In: Bertelsmann Stiftung (Ed.): Strategies for Combating Right-Wing Extremism in Europe. Verlag Bertelsmann-Stiftung: 425-462. - Taggart, Paul. 1996. The New Populism and the New Politics: New Protest Parties in Sweden and in a Comparative Perspective. Basingstoke: Macmillan. - Widfeldt, Anders. 2008. Party Change as a Necessity - The Case of the Sweden Democrats. Representation 44(3): 265-276. Switzerland: Collignon, Stefan, and Omar Serrano. 2007. The Political Economy of Right-wing Populism and Euroscepticism in Switzerland. Unpublished Working Paper, London, Geneva. - Ladner, Andreas. 2001. Swiss Political Parties: Between Persistence 
and Change. West European Politics 24(2): 123-144. - Skenderovic, Damir, and Vera Sperisen. 2009. Country Report Switzerland. In: Bertelsmann Stiftung (ed.): Strategies for Combating Right-Wing Extremism in Europe (Gütersloh: Verlag Bertelsmann-Stiftung 2009): 463-530. - Theiler, Tobias. 2004. The Origins of Euroscepticism in Germanspeaking Switzerland. European Journal of Political Research 43(4): 635-656. - United Kingdom: Eatwell, Roger, and Matthew Goodwin. 2010. The New Extremism in 21st Century Britain. New York: Routledge. - Gifford, Chris. 2006. The Rise of Post-Imperial Populism: The Case of Right-Wing Euroscepticism in Britain. European Journal of Political Research 45(5): 851-869. - Goodwin, Matthew. 2011. New British Fascism: Rise of the British National Party. New York: Routledge. - Hayton, Richard. 2011. Towards the Mainstream? UKIP and the 2009 Elections to the European Parliament. Politics 30(1): 26-35. - Husbands, Christopher (2009): Country Report Great Britain. In: Bertelsmann Stiftung (ed.): Strategies for Combating Right-Wing Extremism in Europe (Gütersloh: Verlag Bertelsmann-Stiftung 2009): 249-284. - United States: Dimaond, Sarah. 1995. Roads to Dominion: Right-wing Movements and Political Power in the United States. New York: Guilford Press. - George, John, and Laird Wilcox. 1995. American Extremists: Militias, Supremacists, Klansmen, Communists, and Others. New York: Prometheus Books. - Lipset, Seymour Martin, and Earl Raab. 1978. The Politics of Unreason: Right-Wing Extremism in America. Essex: Phoenix Books. - Michael, George, and Michael Minkenberg. 2007. A Continuum for Responding to the Extreme Right: A Comparison between the United States and Germany. Studies in Conflict \& Terrorism 30(12): 1109-1123. 


\section{Table B2: List of far-right (R) and far-left (L) parties since 1919 (incl. new Eurosceptic parties)}

AUS R Australia First, Citizens Electoral Council, One Nation, Rise Up Australia

L Communist Party of Australia*, Democratic Socialist Electoral League, Democratic Socialist Perspective, Socialist Alliance

AUT R Alliance for the Future of Austria, Fatherland Block*, Federation of Independents, Freedom Party of Austria, German Nationalists*, Greater German's People's Party*, Movement for Political Renewal, National Socialist German Workers' Party*

L Communists and Left Socialists, Communist Party of Austria*,

BEL $\quad \mathrm{R}$ Flemish Block, Flemish Interest, Flemish Nationalists*, Libertarian-Direct-Democratic, National Front, People's Party, People's Union, Rexists*

L Communist Party of Belgium*, Left Socialist Party, Wallon Labour Party, Worker's Party of Belgium

CAN R No electorally successfull parties identified

L Communist Party of Cananda*, Communist Party of Canada - Marxist-Leninst

CHE R Freedom Party of Switzerland, Geneva Citizens' Movement, National Front*, Swiss Democrats, Swiss People's Party, Ticino League

L Alternative Left, Autonomous Socialist Party, Communist Party of Switzerland*, Progressive Organizations of Switzerland, Solidarity, Swiss Party of Labour

DEU R Action Alliance of Independent Germans, Alternative for Germany, Civil Rights Movement Solidarity, Economic Reconstruction Union, Empowered Citizens, German Community, German National People's Party*, German Party, Reconstruction German People's Union, German Right Party, Law and Order Offensive, National Democratic Party of Germany, National Socialist German Workers' Party*, Organization of the National Collection, Patriots for Germany, Popular Vote, Pro Germany, Pro German Middle, Statt Party, The Offensive

L Action Democratic Progress, Alliance of Germans, Collection to Action, Communist Party of Germany*, German Communist Party, German Union for Peace, Marxist-Leninist Party of Germany, The Left

DNK R Danish People's Party, National Socialist Worker's Party of Denmark*, Progress Party

L Communist Party of Denmark*, Common Course, Left Socialists, Socialist People's Party, Unity List - The RedGreens

ESP R Falange Española*, Basque Nationalists*

L Catalan Nationalists*, Communist Party of Spain*, Workers' Party of Marxist Unification*, United Left

FIN R Finns Party, Finish Rural Party, Patriotic People's Movement*

L Communist Worker's Party, Communist Party of Finland*, Finnish People's Democratic League, Left Alliance

R Movement for France, National Front, National Repulican Movement

L French Communist Party*, Left Front, Revolutionary Communist League, Worker's Struggle

GBR R British National Party, Democratic Unionist Party, English Democrats, National Democratic Party, National Front, United Kingdom Independence Party

L Communist Party of Great Britain*, Green Party of England and Wales, Plaid Cymru, Respect Party, Scottish Socialist Party, Sinn Féin, Socialist Alternative, Socialist Labor Party

GRC R Freethinkers' Party*, Golden Dawn, Independent Greeks, National Democratic Union, National Political Union, Popular Independent Alignment, Popular Orthodox Rally

L Coalition of the Radical Left, Communist Party of Greece*, Communist Party of Greece (Interior), Democratic Left, Synaspismos, United Democratic Left

IRL R No electorally successful parties identified

L Communist Party of Ireland*, Democratic Left, National Progressive Democrats, People Before Profit Alliance, Sinn Féin, Socialist Labour Party, Socialist Party, Workers Party

ITA R Brothers of Italy, Casa Pound, Ex-Servicemen Party*, Italian Social Movement, National Alliance, National Fascist Party*, New Force, No Euro, Northern League, Social Alternative, The Freedomites, The Right, Tricolour Flame

L Civil Revolution, Communist Refoundation Party, Communist Worker's Party, Critical Left, Democratic Party of the Left, Five Star Movement, Italian Communist Party*, Party of Italian Communists

R Japan Restauration Party

L Japanese Communist Party

NLD

R Centre Democrats, Centre Party, Democratic Political Turning Point, Liveable Netherland, National Socialist Movement in the Netherlands*, One NL, Party for Freedom, Patriotic Democratic Appeal, Pim Fortyn List, Proud of the

L Communist Party of the Netherlands*, New Communist Party of the Netherlands, Pacifist Socialist Party, Socialist Party

NOR R Democrats in Norway, Fatherland Party, National Socialist Party of Norway*, Norwegian People's Party, Progress Party, The Democrats

L Communist Party of Norway, Socialist Left Party, The Red Party

PRT R Democratic and Social Centre - People's Party, National Renovator Party

L Democratic Unitarian Coalition, Left Bloc, Left Revolutionary Front, People's Democratic Union, People's Socialist Front, Portuguese Communist Party*. Portuguese Labour Party, Portuguese Workers' Communist Party, Revolutionary Socialist Party, United People Alliance, Workers Party of Socialist Unity

SWE R National Socialist Party*, National League of Sweden*, New Democracy, Sweden Democrats

L Communist Party of Sweden*, The Left Party

R No electorally successful parties identified

L No electorally successful parties identified

Notes: *Parties with an asterisk are those participating in elections between 1919-1938. Some of these (e.g., French Communist Party) still exist today, some have dissolved, some were banned (e.g., Communist Party of Germany), some were merged into new parties, or changed their name over time (e.g., Flemish Nationalists to Flemish Block to Flemish Interest). In our analysis we always calculate the vote share of all then-current far-right and far-left parties. 


\section{B.3 Coding of government and opposition parties}

This section lists the sources used to classify parties into government and opposition. The classification for the post-World War II period mainly follows Döring and Manow (2012) $(\mathrm{D} / \mathrm{M})$. The remaining historical and country-specific sources are listed below:

Australia: 1901-2013: D/M. - Austria: 1919-1930: Website of the Austrian government. Available at www.parlament.gv . at/WWER/BREG/REG. 1945-2013: N/S. Belgium: 1870.2-1939: Website of the Belgian government. Available at www.premier.fgov.be; 1946-2014: D/M. - Canada: 1872-1940: Privy Council Office. 2013. A Guide to Canadian Ministries since Confederation. Ottawa. Available at www.pco-bcp.gc.ca/mgm; 19452011: D/M. - Denmark: 1901-1943: Website of the Danish government. Available at www.stm.dk; 1945-2011: D/M. - Finland: 1919-1924: The Finnish Government. 2014. Government and Ministers since 1917. Helsinki. Availabe at www.valtioneuvosto.fi/ tietoa/historiaa/hallitukset-ja-ministerit; 1927-2011: D/M. - France 1871-1936: Website of the French government. Available at www.gouvernement.fr; 1945-2012: D/M. - Germany: 1919-1932.2: Lothar Gall, and Michael Hollman. 2009. Reich Chancellery Files: Weimar Republic Edition (Online Version). Available at www.bundesarchiv.de/ aktenreichskanzlei/1919-1933/0000/index.html; 1949-2013: D/M. - Greece: 18891964: Henisz, Witold. 2000. The Institutional Environment for Economic Growth. Economics and Politics. 12(1): 1-31; 1974-2012.2: D/M. - Ireland: 1918-1943: Website of the Irish government. Available at www.taoiseach.gov.ie/eng/historical_ information/history_of_government; 1944-2011: D/M. - Italy: 1874-1921: Henisz, Witold. 2000. The Institutional Environment for Economic Growth. Economics and Politics. 12(1): 1-31; 1946-2013: D/M. - Japan: 1946-2014: D/M. - Netherlands: 1888-1937: Website of the Dutch government. Available at www .government.nl; 1946-2012: D/M. - Norway: 1885-1936: Government Administration Services. Information from the Government and the Ministries. Norway's Governments since 1814. Available at www.regjeringen.no/en/the-government/previous-governments; 1945-2013: D/M. Portugal: 1911-1925: Henisz, Witold. 2000. The Institutional Environment for Economic Growth. Economics and Politics. 12(1): 1-31; 1975-2011: D/M. - Spain: 1873, 1931-1936: Henisz, Witold. 2000. The Institutional Environment for Economic Growth. Economics and Politics. 12(1): 1-31; 1977-2011: D/M. - Sweden: 1917-1940: Website of the Swedish government. Available at www.government.se/sb/d/576; 1944-2014: D/M. - Switzerland: 1872-1917: The Federal Authorities of the Swiss Confederation. All Federal Councillors since 1848. Bern. Available at www.admin.ch/gov/en/start/federal-council.html; 1919-2011: D/M. - United Kingdom: 1874-1935: Cook, Chris, and Brendan Keith. 1984. British Historical Facts, 1830-1900. Palgrave Macmillan, Butler, David. 2000. Twentieth Century British Political Facts, 1900-2000. Palgrave Macmillan, Henisz, Witold. 2000. The Institutional Environment for Economic Growth. Economics and Politics. 12(1): 1-31; 1945-2010: D/M. - United States: 1870-2014: United States government. Website of the White House. Available at www.whitehouse.gov/about/presidents. 


\section{B.4 Coding the fractionalization measure}

To measure parliamentary fractionalization it is essential to define what a party is. This is not always straightforward. To define parties we follow the approach used by Beck et al. (2001) and apply it to all parliaments since 1870. Specifically, we use the following coding rules:

- We split up party umbrellas and electoral fronts and count the parties individually if one or more of the following conditions are met: (1) the parties in the front compete for seats, (2) two or more parties within the front put forward their own presidential/premier candidates, and/or (3) the sources indicate that cabinet positions have been distributed among members of the different parties forming the front. If none of these are true, the front is recorded as a single party. If the sources only provide seats for the front, we regard the front as one party. In case of ambiguities, the front is considered to be one party.

- If parties have several wings based on language or ethnic divisions (e.g. Belgium), the wings are treated as separate or united depending on how the voting results and seats are reported in statistical sources. If the seats are broken down by wing they are classified as separate parties; if seats are only reported for the overall party, we regard it as one party.

- Independent deputies are treated as if they were individual parties with one seat each. This applies for the fractionalization measure, but not for our variable that represents the number of parties in the legislature.

- Unless otherwise stated parties and independent deputies from autonomous or semiautonomous territories are included when sources indicate their presence in the parliament (e.g., France or Denmark). 


\section{Appendix C Coding of street protest variables}

Figure C1: Street protests: variation over time

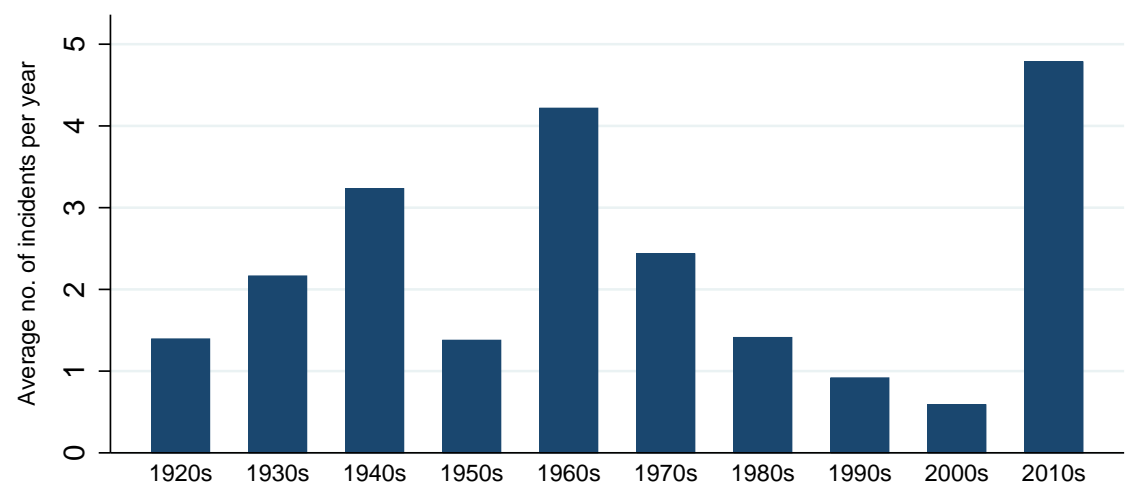

Notes: The figure shows the number of street protest incidents per year, averaged over the decades from the 1920 s to the 2010s. Note that the 2010s column in the lower panel refers only to the years 2010-2012. 


\section{Appendix D Financial crises and recession dates}

Table D1: Financial crisis events, 1870-2014

\begin{tabular}{lccccccccc}
\hline \hline Australia & 1893 & 1989 & & & & & & \\
Austria & 1873 & 1924 & 1929 & 2008 & & & & & \\
Belgium & 1870 & 1885 & 1925 & 1931 & $1939^{*}$ & 2008 & & \\
Canada & 1873 & 1907 & 1923 & & & & & \\
Denmark & 1877 & 1885 & 1908 & 1921 & 1931 & 1987 & 2008 & & \\
Finland & 1878 & 1900 & 1921 & 1931 & 1991 & & & \\
France & 1882 & 1889 & 1907 & 1930 & 2008 & & & & \\
Germany & 1873 & 1891 & 1901 & 1907 & 1931 & 2008 & & & \\
Greece & 1931 & 1991 & 2008 & & & & & & \\
Ireland & 2008 & & & & & & & \\
Italy & 1873 & 1887 & 1893 & 1907 & 1921 & 1930 & $1935^{*}$ & 1990 & 2008 \\
Japan & 1882 & 1900 & $1904^{*}$ & 1907 & 1913 & 1927 & 1992 & & \\
Netherlands & 1893 & 1907 & 1921 & $1939^{*}$ & 2008 & & & & \\
Norway & 1899 & 1922 & 1931 & 1988 & & & & & \\
Portugal & 1890 & 1920 & $1923^{*}$ & 1931 & 2008 & & & \\
Spain & 1883 & 1890 & 1913 & 1920 & $1924^{*}$ & 1931 & 1978 & 2008 & \\
Sweden & 1878 & 1907 & 1922 & 1931 & 1991 & 2008 & & & \\
Switzerland & 1870 & 1910 & 1931 & 1991 & 2008 & & & & \\
United Kingdom & 1873 & 1890 & 1974 & 1984 & 1991 & 2007 & & \\
United States & 1873 & 1884 & 1893 & 1907 & 1929 & 1984 & 2007 & & \\
\hline \hline
\end{tabular}

Notes: Financial crisis events from Bordo et al. (2001), Reinhart and Rogoff (2009b), Laeven and Valencia $(2008 ; 2012)$, and Jordà, Schularick, and Taylor (2013). The table shows all financial crisis events in the 20 countries in our sample since $1870{ }^{*}=$ crises removed from the OLS regression. Italics $=$ crises removed from the descriptive analysis. 
Table D2: Financial recessions (F) and normal recessions (N), 1870-2014

\begin{tabular}{|c|c|c|c|c|c|c|c|c|c|c|c|c|}
\hline \multirow[t]{4}{*}{ Australia } & $\mathrm{N}$ & 1875 & 1878 & 1881 & 1883 & 1885 & 1887 & 1889 & 1896 & 1898 & 1900 & $\overline{1904}$ \\
\hline & & 1910 & 1913 & 1926 & 1938 & 1943 & 1951 & 1956 & 1961 & 1973 & 1976 & 1981 \\
\hline & & 2008 & & & & & & & & & & \\
\hline & $\mathrm{F}$ & 1891 & 1894 & 1989 & & & & & & & & \\
\hline \multirow[t]{3}{*}{ Austria } & $\mathrm{N}$ & 1878 & 1884 & 1887 & 1892 & 1899 & 1907 & 1912 & 1915 & 1922 & 1939 & 1941 \\
\hline & & 1943 & 1974 & 1977 & 1980 & 1983 & 1992 & 2012 & & & & \\
\hline & $\mathrm{F}$ & 1872 & 1874 & 1922 & 1929 & 2008 & & & & & & \\
\hline \multirow[t]{3}{*}{ Belgium } & $\mathrm{N}$ & 1872 & 1874 & 1887 & 1890 & 1900 & 1913 & 1916 & 1942 & 1951 & 1957 & 1974 \\
\hline & & 1980 & 1992 & 2011 & & & & & & & & \\
\hline & $\mathrm{F}$ & 1870 & 1883 & 1926 & 1930 & 1937 & 2008 & & & & & \\
\hline \multirow[t]{3}{*}{ Canada } & $\mathrm{N}$ & 1871 & 1877 & 1882 & 1888 & 1891 & 1894 & 1903 & 1913 & 1917 & 1928 & 1944 \\
\hline & & 1947 & 1953 & 1956 & 1981 & 1989 & 2007 & & & & & \\
\hline & $\mathrm{F}$ & 1874 & 1907 & & & & & & & & & \\
\hline \multirow[t]{3}{*}{ Denmark } & $\mathrm{N}$ & 1870 & 1880 & 1887 & 1911 & 1914 & 1923 & 1939 & 1944 & 1950 & 1962 & 1973 \\
\hline & & 1979 & 1992 & 2011 & & & & & & & & \\
\hline & $\mathrm{F}$ & 1872 & 1876 & 1883 & 1920 & 1931 & 1987 & 2007 & & & & \\
\hline \multirow[t]{3}{*}{ Finland } & $\mathrm{N}$ & 1870 & 1883 & 1890 & 1898 & 1907 & 1913 & 1916 & 1938 & 1941 & 1943 & 1952 \\
\hline & & 1957 & 1975 & 2008 & 2011 & & & & & & & \\
\hline & $\mathrm{F}$ & 1876 & 1900 & 1929 & 1989 & & & & & & & \\
\hline \multirow[t]{3}{*}{ France } & $\mathrm{N}$ & 1872 & 1874 & 1892 & 1894 & 1896 & 1900 & 1905 & 1907 & 1909 & 1912 & 1916 \\
\hline & & 1920 & 1926 & 1933 & 1937 & 1939 & 1942 & 1974 & 1992 & 2012 & & \\
\hline & $\mathrm{F}$ & 1882 & 1929 & 2007 & & & & & & & & \\
\hline \multirow[t]{3}{*}{ Germany } & $\mathrm{N}$ & 1879 & 1898 & 1905 & 1913 & 1922 & 1943 & 1966 & 1974 & 1980 & 1992 & 2001 \\
\hline & & 2012 & & & & & & & & & & \\
\hline & $\mathrm{F}$ & 1875 & 1890 & 1908 & 1928 & 2008 & & & & & & \\
\hline \multirow[t]{4}{*}{ Greece } & $\mathrm{N}$ & 1873 & 1879 & 1882 & 1885 & 1888 & 1895 & 1899 & 1902 & 1905 & 1907 & 1909 \\
\hline & & 1911 & 1914 & 1916 & 1918 & 1921 & 1926 & 1935 & 1937 & 1939 & 1943 & 1951 \\
\hline & & 1973 & 1979 & 1986 & 1989 & & & & & & & \\
\hline & $\mathrm{F}$ & 1930 & 1991 & 2008 & & & & & & & & \\
\hline \multirow[t]{3}{*}{ Ireland } & $\mathrm{N}$ & 1925 & 1931 & 1936 & 1938 & 1941 & 1944 & 1955 & 1957 & 1975 & 1982 & 1985 \\
\hline & & 2011 & & & & & & & & & & \\
\hline & $\mathrm{F}$ & 2007 & & & & & & & & & & \\
\hline \multirow[t]{3}{*}{ Italy } & $\mathrm{N}$ & 1870 & 1883 & 1897 & 1918 & 1923 & 1925 & 1932 & 1939 & 1974 & 2002 & 2004 \\
\hline & & 2010 & & & & & & & & & & \\
\hline & $\mathrm{F}$ & 1873 & 1887 & 1891 & 1929 & 1992 & 2007 & & & & & \\
\hline$\overline{\text { Japan }}$ & $\mathrm{N}$ & 1875 & 1877 & 1880 & 1887 & 1890 & 1892 & 1895 & 1898 & 1903 & 1919 & 1921 \\
\hline & & 1929 & 1933 & 1940 & 1973 & 2001 & 2007 & 2010 & & & & \\
\hline & $\mathrm{F}$ & 1874 & 1901 & 1907 & 1913 & 1925 & 1997 & & & & & \\
\hline Netherlands & $\mathrm{N}$ & 1870 & 1873 & 1877 & 1889 & 1894 & 1899 & 1902 & 1913 & 1929 & 1957 & 1974 \\
\hline & & 1980 & 2001 & 2011 & & & & & & & & \\
\hline & $\mathrm{F}$ & 1892 & 1906 & 1937 & 1939 & 2008 & & & & & & \\
\hline Norway & $\mathrm{N}$ & 1876 & 1881 & 1885 & 1893 & 1902 & 1916 & 1923 & 1939 & 1941 & 1957 & 1981 \\
\hline & & 2007 & 2012 & & & & & & & & & \\
\hline & $\mathrm{F}$ & 1897 & 1920 & 1930 & 1987 & & & & & & & \\
\hline Portugal & $\mathrm{N}$ & 1870 & 1873 & 1877 & 1888 & 1893 & 1900 & 1904 & 1907 & 1912 & 1914 & 1916 \\
\hline & & 1925 & 1927 & 1934 & 1937 & 1939 & 1941 & 1944 & 1947 & 1951 & 1973 & \\
\hline & & 1982 & 1992 & 2002 & 2004 & 2010 & & & & & & \\
\hline & $\mathrm{F}$ & 1890 & 1923 & 1929 & 2007 & & & & & & & \\
\hline Spain & $\mathrm{N}$ & 1873 & 1877 & 1892 & 1894 & 1901 & 1909 & 1911 & 1916 & 1927 & 1932 & 1935 \\
\hline & & 1940 & 1944 & 1947 & 1952 & 1958 & 1974 & 1980 & 1992 & 2011 & & \\
\hline & $\mathrm{F}$ & 1883 & 1889 & 1913 & 1925 & 1929 & 1978 & 2007 & & & & \\
\hline Sweden & $\mathrm{N}$ & 1873 & 1876 & 1881 & 1883 & 1885 & 1888 & 1890 & 1899 & 1901 & 1904 & $\overline{1913}$ \\
\hline & & 1916 & 1924 & 1939 & 1976 & 1980 & 2011 & & & & & \\
\hline & $\mathrm{F}$ & 1878 & 1907 & 1920 & 1930 & 1990 & 2007 & & & & & \\
\hline Switzerland & $\mathrm{N}$ & 1875 & 1880 & 1886 & 1890 & 1893 & 1899 & 1902 & 1906 & 1912 & 1916 & $\overline{1920}$ \\
\hline & & 1933 & 1939 & 1947 & 1951 & 1957 & 1974 & 1981 & 1994 & 2001 & & \\
\hline & $\mathrm{F}$ & 1871 & 1929 & 1990 & 2008 & & & & & & & \\
\hline$\overline{\text { U.K. }}$ & $\mathrm{N}$ & 1891 & 1875 & 1877 & 1883 & 1896 & 1899 & 1902 & 1907 & 1918 & 1925 & $\overline{1929}$ \\
\hline & & 1938 & 1943 & 1951 & 1957 & 1979 & 2010 & & & & & \\
\hline & $\mathrm{F}$ & 1873 & 1889 & 1973 & 1990 & 2007 & & & & & & \\
\hline$\overline{\mathrm{USA}}$ & $\mathrm{N}$ & 1875 & 1887 & 1889 & 1895 & 1901 & 1909 & 1913 & 1916 & 1918 & 1926 & 1937 \\
\hline & & 1944 & 1948 & 1953 & 1957 & 1969 & 1973 & 1979 & 1981 & 1990 & 2000 & \\
\hline & $\mathrm{F}$ & 1873 & 1882 & 1892 & 1906 & 1929 & 2007 & & & & & \\
\hline
\end{tabular}


Table D3: Non-financial macro-economic disasters, 1870-2014

\begin{tabular}{lllllllll}
\hline \hline Australia & 1881 & 1889 & 1896 & 1926 & 1981 & & & \\
Austria & 1912 & 1915 & 1943 & & & & & \\
Belgium & 1913 & 1916 & 1942 & & & & & \\
Canada & 1877 & 1884 & 1913 & 1917 & 1928 & 1944 & 1953 & 1981 \\
Denmark & 1877 & 1884 & 1914 & 1916 & 1939 & 1944 & 1953 & 1981 \\
Finland & 1890 & 1913 & 1916 & 1938 & 2008 & 2011 & & \\
France & 1892 & 1909 & 1912 & 1920 & 1939 & 1942 & 2012 & \\
Germany & 1879 & 1913 & 1922 & 1943 & & & & \\
Greece & 1973 & 1885 & 1888 & 1894 & 1896 & 1899 & 1911 & 1918 \\
& 1921 & 1926 & 1935 & 1939 & 1973 & 1986 & & \\
Ireland & none & & & & & & & \\
Italy & 1918 & 1939 & 1974 & 2010 & & & & \\
Japan & 1880 & 1887 & 1890 & 1895 & 1898 & 1919 & 1929 & 1940 \\
& 1973 & 2007 & & & & & & \\
Netherlands & 1873 & 1913 & & & & & & \\
Norway & 1873 & 1916 & 1939 & 1941 & & & & \\
Portugal & 1916 & 1927 & 1934 & 1939 & 1973 & & & \\
Spain & 1873 & 1877 & 1894 & 1909 & 1935 & & & \\
Sweden & 1916 & 1939 & & & & & & \\
Switzerland & 1875 & 1890 & 1893 & 1916 & 1920 & 1939 & 1957 & 1974 \\
United Kingdom & 1907 & 1918 & 1925 & 1929 & 1943 & & & \\
United States & 1895 & 1913 & 1918 & 1937 & 1944 & 1957 & 1981 & \\
\hline \hline
\end{tabular}

Notes: The table shows a sub-sample of non-financial macro-economic disasters from the normal recessions listed in Table D2. Non-financial macro-economic disasters are defined as normal recessions where the yearly real p.c. GDP precentage loss is higher than the average in financial crisis recessions. Thresholds are calculated separately for the pre-World War II sample $(-3.35 \%)$ and the post-World War II sample (-2.55\%). 


\section{Appendix E Local projections}

Table E1: Local projections of government vote shares

\begin{tabular}{|c|c|c|c|c|c|}
\hline (a) Full sample & Year 1 & Year 2 & Year 3 & Year 4 & Year 5 \\
\hline Financial recession & $\begin{array}{l}-2.20 \\
(1.77)\end{array}$ & $\begin{array}{l}-3.41 \\
(2.41)\end{array}$ & $\begin{array}{l}-0.92 \\
(2.89)\end{array}$ & $\begin{array}{c}0.55 \\
(3.26)\end{array}$ & $\begin{array}{l}-1.58 \\
(2.77)\end{array}$ \\
\hline Normal recession & $\begin{array}{c}0.89 \\
(1.16)\end{array}$ & $\begin{array}{l}1.84^{*} \\
(1.00)\end{array}$ & $\begin{array}{c}1.78 \\
(1.86)\end{array}$ & $\begin{array}{l}3.41^{*} \\
(1.82)\end{array}$ & $\begin{array}{c}3.03 \\
(1.77)\end{array}$ \\
\hline Non-financial macro disaster & $\begin{array}{c}2.23 \\
(3.91)\end{array}$ & $\begin{array}{c}4.65 \\
(3.99)\end{array}$ & $\begin{array}{l}9.66^{* *} \\
(4.04)\end{array}$ & $\begin{array}{c}5.39 \\
(3.32)\end{array}$ & $\begin{array}{c}2.30 \\
(5.00)\end{array}$ \\
\hline $\mathrm{H}_{0}$ : Financial = normal; $\mathrm{p}$-value & 0.08 & 0.03 & 0.39 & 0.47 & 0.13 \\
\hline $\mathrm{H}_{0}:$ Financial $=$ disaster; $\mathrm{p}$-value & 0.18 & 0.11 & 0.05 & 0.37 & 0.53 \\
\hline$R^{2}$ & 0.135 & 0.233 & 0.303 & 0.352 & 0.368 \\
\hline Observations & 1770 & 1740 & 1711 & 1684 & 1659 \\
\hline (b) Pre-WWII sample & Year 1 & Year 2 & Year 3 & Year 4 & Year 5 \\
\hline Financial recession & $\begin{array}{l}-1.31 \\
(3.68)\end{array}$ & $\begin{array}{c}1.09 \\
(4.67)\end{array}$ & $\begin{array}{c}3.79 \\
(6.12)\end{array}$ & $\begin{array}{c}1.79 \\
(6.45)\end{array}$ & $\begin{array}{l}-4.92 \\
(4.78)\end{array}$ \\
\hline Normal recession & $\begin{array}{c}2.33 \\
(2.29)\end{array}$ & $\begin{array}{c}3.73 \\
(2.29)\end{array}$ & $\begin{array}{c}2.20 \\
(3.31)\end{array}$ & $\begin{array}{c}4.93 \\
(3.15)\end{array}$ & $\begin{array}{c}2.78 \\
(3.27)\end{array}$ \\
\hline Non-financial macro disaster & $\begin{array}{c}6.06 \\
(9.89)\end{array}$ & $\begin{array}{l}10.94 \\
(9.54)\end{array}$ & $\begin{array}{l}10.72 \\
(8.07)\end{array}$ & $\begin{array}{c}8.53 \\
(8.42)\end{array}$ & $\begin{array}{c}2.75 \\
(8.39)\end{array}$ \\
\hline $\mathrm{H}_{0}$ : Financial = normal; $\mathrm{p}$-value & 0.19 & 0.56 & 0.82 & 0.65 & 0.08 \\
\hline $\mathrm{H}_{0}:$ Financial = disaster; $\mathrm{p}$-value & 0.32 & 0.27 & 0.42 & 0.49 & 0.42 \\
\hline$R^{2}$ & 0.130 & 0.227 & 0.300 & 0.334 & 0.355 \\
\hline Observations & 591 & 582 & 574 & 567 & 562 \\
\hline (c) Post-WWII sample & Year 1 & Year 2 & Year 3 & Year 4 & Year 5 \\
\hline Financial recession & $\begin{array}{l}-3.53^{*} \\
(1.90)\end{array}$ & $\begin{array}{c}-9.12^{* * *} \\
(2.72)\end{array}$ & $\begin{array}{c}-6.75^{* *} \\
(2.85)\end{array}$ & $\begin{array}{l}-4.45^{*} \\
(2.18)\end{array}$ & $\begin{array}{l}-4.86 \\
(2.84)\end{array}$ \\
\hline Normal recession & $\begin{array}{l}-0.78 \\
(1.56)\end{array}$ & $\begin{array}{l}-0.47 \\
(1.57)\end{array}$ & $\begin{array}{l}-0.26 \\
(1.48)\end{array}$ & $\begin{array}{c}0.24 \\
(1.18)\end{array}$ & $\begin{array}{l}-0.23 \\
(1.44)\end{array}$ \\
\hline Non-financial macro disaster & $\begin{array}{l}-1.10 \\
(1.53)\end{array}$ & $\begin{array}{c}0.31 \\
(2.69)\end{array}$ & $\begin{array}{l}9.43^{*} \\
(5.28)\end{array}$ & $\begin{array}{l}3.27^{* *} \\
(1.52)\end{array}$ & $\begin{array}{c}0.19 \\
(6.66)\end{array}$ \\
\hline $\mathrm{H}_{0}$ : Financial $=$ normal; $\mathrm{p}$-value & 0.34 & 0.02 & 0.02 & 0.10 & 0.20 \\
\hline $\mathrm{H}_{0}:$ Financial $=$ disaster; $\mathrm{p}$-value & 0.38 & 0.05 & 0.01 & 0.01 & 0.48 \\
\hline$R^{2}$ & 0.203 & 0.342 & 0.429 & 0.495 & 0.521 \\
\hline Observations & 1179 & 1158 & 1137 & 1117 & 1097 \\
\hline
\end{tabular}

Notes: ${ }^{* * *}$ Significant at $.01 .{ }^{* *}$ Significant at $.05 .{ }^{*}$ Significant at .1. Robust standard errors (clustered by country) in parentheses. Results correspond to local projections of cumulative change in 100 times the logged variable relative to peak for years $1-5$ of the financial recession (first row), normal recession (second row), and non-financial macro disaster (third row). (a) 1870-2014, (b) 1870-1938, (c) 1950-2014. World War I (1914-1918) and World War II (1939-1949) excluded. Financial $=$ normal (disaster) tests the null that coefficients for each type of recession are the same for the intercept terms in the first and second (third) rows. In each case the p-value of the test is provided. The controls are contemporaneous and 1-year lagged values of the growth rate of GDP per capita and the CPI inflation rate at peak (coefficients not reported). See text. 
Table E2: Local projections of opposition vote shares

\begin{tabular}{|c|c|c|c|c|c|}
\hline (a) Full sample & Year 1 & Year 2 & Year 3 & Year 4 & Year 5 \\
\hline Financial recession & $\begin{array}{c}1.62 \\
(1.82)\end{array}$ & $\begin{array}{c}2.56 \\
(3.31)\end{array}$ & $\begin{array}{l}-0.85 \\
(3.77)\end{array}$ & $\begin{array}{l}-2.42 \\
(4.40)\end{array}$ & $\begin{array}{l}-1.42 \\
(3.95)\end{array}$ \\
\hline Normal recession & $\begin{array}{l}-2.25 \\
(2.43)\end{array}$ & $\begin{array}{l}-3.60 \\
(2.56)\end{array}$ & $\begin{array}{l}-1.19 \\
(3.30)\end{array}$ & $\begin{array}{l}-4.80 \\
(4.11)\end{array}$ & $\begin{array}{l}-4.16 \\
(3.98)\end{array}$ \\
\hline Non-financial macro disaster & $\begin{array}{l}-5.22 \\
(7.20)\end{array}$ & $\begin{array}{r}-10.60 \\
(7.39)\end{array}$ & $\begin{array}{l}-16.83 \\
(9.74)\end{array}$ & $\begin{array}{l}-8.77 \\
(9.21)\end{array}$ & $\begin{array}{r}-13.82 \\
(8.88)\end{array}$ \\
\hline $\mathrm{H}_{0}$ : Financial $=$ normal; $\mathrm{p}$-value & 0.13 & 0.09 & 0.94 & 0.70 & 0.52 \\
\hline $\mathrm{H}_{0}:$ Financial = disaster; $\mathrm{p}$-value & 0.30 & 0.13 & 0.14 & 0.56 & 0.23 \\
\hline $\begin{array}{l}R^{2} \\
\text { Observations }\end{array}$ & $\begin{array}{l}0.058 \\
1770\end{array}$ & $\begin{array}{c}0.103 \\
1740\end{array}$ & $\begin{array}{c}0.137 \\
1711\end{array}$ & $\begin{array}{l}0.168 \\
1684\end{array}$ & $\begin{array}{c}0.189 \\
1659\end{array}$ \\
\hline (b) Pre-WWII sample & Year 1 & Year 2 & Year 3 & Year 4 & Year 5 \\
\hline Financial recession & $\begin{array}{c}3.03 \\
(3.31)\end{array}$ & $\begin{array}{c}1.99 \\
(6.53)\end{array}$ & $\begin{array}{c}0.25 \\
(7.58)\end{array}$ & $\begin{array}{c}2.26 \\
(8.25)\end{array}$ & $\begin{array}{c}9.23 \\
(6.66)\end{array}$ \\
\hline Normal recession & $\begin{array}{l}-2.72 \\
(4.69)\end{array}$ & $\begin{array}{l}-4.53 \\
(4.21)\end{array}$ & $\begin{array}{l}-0.39 \\
(4.33)\end{array}$ & $\begin{array}{l}-9.14 \\
(6.91)\end{array}$ & $\begin{array}{l}-4.18 \\
(8.18)\end{array}$ \\
\hline Non-financial macro disaster & $\begin{array}{l}-12.83 \\
(18.78)\end{array}$ & $\begin{array}{l}-20.27 \\
(19.29)\end{array}$ & $\begin{array}{l}-17.56 \\
(19.46)\end{array}$ & $\begin{array}{l}-14.83 \\
(19.59)\end{array}$ & $\begin{array}{l}-12.16 \\
(17.91)\end{array}$ \\
\hline $\mathrm{H}_{0}:$ Financial $=$ normal; $\mathrm{p}$-value & 0.12 & 0.35 & 0.95 & 0.30 & 0.12 \\
\hline $\mathrm{H}_{0}:$ Financial $=$ disaster; $\mathrm{p}$-value & 0.34 & 0.24 & 0.38 & 0.42 & 0.30 \\
\hline $\begin{array}{l}R^{2} \\
\text { Observations }\end{array}$ & $\begin{array}{c}0.071 \\
591\end{array}$ & $\begin{array}{c}0.125 \\
582\end{array}$ & $\begin{array}{c}0.162 \\
574\end{array}$ & $\begin{array}{c}0.210 \\
567\end{array}$ & $\begin{array}{c}0.255 \\
562\end{array}$ \\
\hline (c) Post-WWII sample & Year 1 & Year 2 & Year 3 & Year 4 & Year 5 \\
\hline Financial recession & $\begin{array}{c}3.82 \\
(2.35)\end{array}$ & $\begin{array}{c}11.23^{* * *} \\
(3.76)\end{array}$ & $\begin{array}{l}8.16^{* *} \\
(3.08)\end{array}$ & $\begin{array}{l}6.00^{*} \\
(2.88)\end{array}$ & $\begin{array}{l}6.29^{*} \\
(3.01)\end{array}$ \\
\hline Normal recession & $\begin{array}{l}-0.52 \\
(2.52)\end{array}$ & $\begin{array}{l}-0.89 \\
(3.08)\end{array}$ & $\begin{array}{l}1.79 \\
(2.92)\end{array}$ & $\begin{array}{c}2.31 \\
(2.53)\end{array}$ & $\begin{array}{c}2.10 \\
(2.56)\end{array}$ \\
\hline Non-financial macro disaster & $\begin{array}{c}1.31 \\
(1.51)\end{array}$ & $\begin{array}{l}-3.72 \\
(6.60)\end{array}$ & $\begin{array}{l}-18.06 \\
(12.26)\end{array}$ & $\begin{array}{l}-4.06 \\
(5.93)\end{array}$ & $\begin{array}{r}-11.17 \\
(6.67)\end{array}$ \\
\hline $\begin{array}{l}\mathrm{H}_{0}: \text { Financial }=\text { normal } ; \mathrm{p} \text {-value } \\
\mathrm{H}_{0}: \text { Financial }=\text { disaster } ; \text {-value }\end{array}$ & $\begin{array}{l}0.27 \\
0.43\end{array}$ & $\begin{array}{l}0.03 \\
0.10\end{array}$ & $\begin{array}{l}0.10 \\
0.04\end{array}$ & $\begin{array}{l}0.44 \\
0.07\end{array}$ & $\begin{array}{l}0.35 \\
0.01\end{array}$ \\
\hline $\begin{array}{l}R^{2} \\
\text { Observations }\end{array}$ & $\begin{array}{l}0.138 \\
1179\end{array}$ & $\begin{array}{l}0.261 \\
1158\end{array}$ & $\begin{array}{l}0.363 \\
1137\end{array}$ & $\begin{array}{l}0.455 \\
1117\end{array}$ & $\begin{array}{l}0.527 \\
1097\end{array}$ \\
\hline
\end{tabular}

Notes: ${ }^{* * *}$ Significant at $.01 .{ }^{* *}$ Significant at .05. ${ }^{*}$ Significant at .1. Robust standard errors (clustered by country) in parentheses. Results correspond to local projections of cumulative change in 100 times the logged variable relative to peak for years 1-5 of the financial recession (first row), normal recession (second row), and non-financial macro disaster (third row). The top panel (a) covers the years 1870-2014, the middle panel (b) covers the years 1870-1938, and the bottom panel (c) covers the years 1950-2014. World War I years (1914-1918) and World War II years (1939-1949) are excluded. Financial $=$ normal tests the null that coefficients for each type of recession are the same for the intercept terms in the first and second rows. Financial $=$ disaster tests the null that coefficients for each type of recession are the same for the intercept terms in the first and third rows. In each case the p-value of the test is provided. The controls are contemporaneous and 1-year lagged values of the growth rate of GDP per capita and the CPI inflation rate at peak (coefficients not reported). See text. 
Table E3: Local projections of parliamentary fractionalization

\begin{tabular}{|c|c|c|c|c|c|}
\hline (a) Full sample & Year 1 & Year 2 & Year 3 & Year 4 & Year 5 \\
\hline Financial recession & $\begin{array}{c}0.40 \\
(0.26)\end{array}$ & $\begin{array}{c}0.61 \\
(0.38)\end{array}$ & $\begin{array}{c}0.38 \\
(0.57)\end{array}$ & $\begin{array}{c}0.43 \\
(0.68)\end{array}$ & $\begin{array}{l}-0.42 \\
(1.04)\end{array}$ \\
\hline Normal recession & $\begin{array}{l}-0.22 \\
(0.16)\end{array}$ & $\begin{array}{c}-0.61^{* *} \\
(0.23)\end{array}$ & $\begin{array}{c}0.19 \\
(0.48)\end{array}$ & $\begin{array}{l}-0.11 \\
(0.54)\end{array}$ & $\begin{array}{l}-0.07 \\
(0.60)\end{array}$ \\
\hline Non-financial macro disaster & $\begin{array}{c}0.12 \\
(0.37)\end{array}$ & $\begin{array}{l}-0.48 \\
(0.47)\end{array}$ & $\begin{array}{c}0.66 \\
(1.39)\end{array}$ & $\begin{array}{c}1.02 \\
(1.21)\end{array}$ & $\begin{array}{c}0.98 \\
(1.46)\end{array}$ \\
\hline $\begin{array}{l}\mathrm{H}_{0}: \text { Financial }=\text { normal } ; \mathrm{p} \text {-value } \\
\mathrm{H}_{0}: \text { Financial }=\text { disaster } \mathrm{p} \text {-value }\end{array}$ & $\begin{array}{l}0.05 \\
0.52\end{array}$ & $\begin{array}{l}0.01 \\
0.10\end{array}$ & $\begin{array}{l}0.72 \\
0.83\end{array}$ & $\begin{array}{l}0.28 \\
0.62\end{array}$ & $\begin{array}{l}0.80 \\
0.55\end{array}$ \\
\hline $\begin{array}{l}R^{2} \\
\text { Observations }\end{array}$ & $\begin{array}{l}0.042 \\
2126\end{array}$ & $\begin{array}{l}0.085 \\
2100\end{array}$ & $\begin{array}{l}0.125 \\
2076\end{array}$ & $\begin{array}{l}0.161 \\
2053\end{array}$ & $\begin{array}{l}0.188 \\
2030\end{array}$ \\
\hline (b) Pre-WWII sample & Year 1 & Year 2 & Year 3 & Year 4 & Year 5 \\
\hline Financial recession & $\begin{array}{c}0.76 \\
(0.48)\end{array}$ & $\begin{array}{c}0.64 \\
(0.45)\end{array}$ & $\begin{array}{c}0.45 \\
(0.67)\end{array}$ & $\begin{array}{c}0.67 \\
(0.83)\end{array}$ & $\begin{array}{l}-0.36 \\
(1.55)\end{array}$ \\
\hline Normal recession & $\begin{array}{l}-0.24 \\
(0.38)\end{array}$ & $\begin{array}{l}-0.96 \\
(0.56)\end{array}$ & $\begin{array}{l}-0.15 \\
(0.40)\end{array}$ & $\begin{array}{l}-0.34 \\
(0.63)\end{array}$ & $\begin{array}{c}0.31 \\
(0.77)\end{array}$ \\
\hline Non-financial macro disaster & $\begin{array}{c}0.50 \\
(0.82)\end{array}$ & $\begin{array}{l}-0.42 \\
(0.95)\end{array}$ & $\begin{array}{l}-0.50 \\
(0.79)\end{array}$ & $\begin{array}{l}-0.00 \\
(0.74)\end{array}$ & $\begin{array}{c}0.88 \\
(1.03)\end{array}$ \\
\hline $\begin{array}{l}\mathrm{H}_{0}: \text { Financial }=\text { normal } ; \mathrm{p} \text {-value } \\
\mathrm{H}_{0}: \text { Financial }=\text { disaster } ; \mathrm{p} \text {-value }\end{array}$ & $\begin{array}{l}0.13 \\
0.70\end{array}$ & $\begin{array}{l}0.03 \\
0.26\end{array}$ & $\begin{array}{l}0.30 \\
0.36\end{array}$ & $\begin{array}{l}0.15 \\
0.47\end{array}$ & $\begin{array}{l}0.73 \\
0.53\end{array}$ \\
\hline $\begin{array}{l}R^{2} \\
\text { Observations }\end{array}$ & $\begin{array}{c}0.057 \\
919\end{array}$ & $\begin{array}{c}0.109 \\
914\end{array}$ & $\begin{array}{c}0.153 \\
910\end{array}$ & $\begin{array}{c}0.187 \\
907\end{array}$ & $\begin{array}{c}0.213 \\
904\end{array}$ \\
\hline (c) Post-WWII sample & Year 1 & Year 2 & Year 3 & Year 4 & Year 5 \\
\hline Financial recession & $\begin{array}{c}0.07 \\
(0.33)\end{array}$ & $\begin{array}{c}0.67 \\
(0.39)\end{array}$ & $\begin{array}{l}0.95^{* *} \\
(0.44)\end{array}$ & $\begin{array}{c}1.36^{* * *} \\
(0.40)\end{array}$ & $\begin{array}{r}1.61^{* * *} \\
(0.45)\end{array}$ \\
\hline Normal recession & $\begin{array}{l}-0.10 \\
(0.17)\end{array}$ & $\begin{array}{l}-0.40 \\
(0.26)\end{array}$ & $\begin{array}{c}0.64 \\
(0.74)\end{array}$ & $\begin{array}{c}0.49 \\
(0.78)\end{array}$ & $\begin{array}{c}0.10 \\
(0.78)\end{array}$ \\
\hline Non-financial macro disaster & $\begin{array}{l}-0.29 \\
(0.38)\end{array}$ & $\begin{array}{l}-0.90 \\
(0.53)\end{array}$ & $\begin{array}{c}2.19 \\
(3.74)\end{array}$ & $\begin{array}{c}2.59 \\
(3.65)\end{array}$ & $\begin{array}{c}1.73 \\
(4.17)\end{array}$ \\
\hline $\begin{array}{l}\mathrm{H}_{0}: \text { Financial }=\text { normal } ; \mathrm{p} \text {-value } \\
\mathrm{H}_{0}: \text { Financial }=\text { disaster } ; \mathrm{p} \text {-value }\end{array}$ & $\begin{array}{l}0.63 \\
0.44\end{array}$ & $\begin{array}{l}0.01 \\
0.01\end{array}$ & $\begin{array}{l}0.71 \\
0.74\end{array}$ & $\begin{array}{l}0.32 \\
0.73\end{array}$ & $\begin{array}{l}0.10 \\
0.98\end{array}$ \\
\hline $\begin{array}{l}R^{2} \\
\text { Observations }\end{array}$ & $\begin{array}{c}0.059 \\
1207\end{array}$ & $\begin{array}{c}0.118 \\
1186\end{array}$ & $\begin{array}{c}0.171 \\
1166\end{array}$ & $\begin{array}{c}0.231 \\
1146\end{array}$ & $\begin{array}{c}0.293 \\
1126\end{array}$ \\
\hline
\end{tabular}

Notes: ${ }^{* * *}$ Significant at $.01 .{ }^{* *}$ Significant at .05. ${ }^{*}$ Significant at .1. Robust standard errors (clustered by country) in parentheses. Results correspond to local projections of cumulative change in 100 times the logged variable relative to peak for years 1-5 of the financial recession (first row), normal recession (second row), and non-financial macro disaster (third row). The top panel (a) covers the years 1870-2014, the middle panel (b) covers the years 1870-1938, and the bottom panel (c) covers the years 1950-2014. World War I years (1914-1918) and World War II years (1939-1949) are excluded. Financial $=$ normal tests the null that coefficients for each type of recession are the same for the intercept terms in the first and second rows. Financial $=$ disaster tests the null that coefficients for each type of recession are the same for the intercept terms in the first and third rows. In each case the p-value of the test is provided. The controls are contemporaneous and 1-year lagged values of the growth rate of GDP per capita and the CPI inflation rate at peak (coefficients not reported). See text. 
Table E4: Local projections of the number of parties in parliament

\begin{tabular}{|c|c|c|c|c|c|}
\hline (a) Full sample & Year 1 & Year 2 & Year 3 & Year 4 & Year 5 \\
\hline Financial recession & $\begin{array}{c}1.58 \\
(1.18)\end{array}$ & $\begin{array}{l}2.13 \\
(1.74)\end{array}$ & $\begin{array}{c}2.26 \\
(2.42)\end{array}$ & $\begin{array}{c}3.38 \\
(2.76)\end{array}$ & $\begin{array}{c}2.19 \\
(3.20)\end{array}$ \\
\hline Normal recession & $\begin{array}{c}0.33 \\
(0.80)\end{array}$ & $\begin{array}{c}0.64 \\
(1.00)\end{array}$ & $\begin{array}{c}2.75^{* *} \\
(1.22)\end{array}$ & $\begin{array}{l}1.80 \\
(1.18)\end{array}$ & $\begin{array}{l}2.38^{*} \\
(1.26)\end{array}$ \\
\hline Non-financial macro disaster & $\begin{array}{l}-0.77 \\
(1.17)\end{array}$ & $\begin{array}{l}2.16 \\
(3.80)\end{array}$ & $\begin{array}{c}5.03 \\
(4.15)\end{array}$ & $\begin{array}{l}7.15^{* *} \\
(3.41)\end{array}$ & $\begin{array}{l}7.42^{*} \\
(3.75)\end{array}$ \\
\hline $\begin{array}{l}\mathrm{H}_{0}: \text { Financial }=\text { normal } ; \mathrm{p} \text {-value } \\
\mathrm{H}_{0}: \text { Financial }=\text { disaster } ; \mathrm{p} \text {-value }\end{array}$ & $\begin{array}{l}0.33 \\
0.12\end{array}$ & $\begin{array}{l}0.42 \\
0.99\end{array}$ & $\begin{array}{l}0.84 \\
0.58\end{array}$ & $\begin{array}{l}0.44 \\
0.43\end{array}$ & $\begin{array}{l}0.96 \\
0.33\end{array}$ \\
\hline $\begin{array}{l}R^{2} \\
\text { Observations }\end{array}$ & $\begin{array}{l}0.047 \\
2147\end{array}$ & $\begin{array}{l}0.085 \\
2122\end{array}$ & $\begin{array}{l}0.115 \\
2096\end{array}$ & $\begin{array}{l}0.143 \\
2070\end{array}$ & $\begin{array}{l}0.171 \\
2044\end{array}$ \\
\hline (b) Pre-WWII sample & Year 1 & Year 2 & Year 3 & Year 4 & Year 5 \\
\hline Financial recession & $\begin{array}{c}2.41 \\
(1.95)\end{array}$ & $\begin{array}{l}3.75 \\
(2.42)\end{array}$ & $\begin{array}{l}4.99^{*} \\
(2.39)\end{array}$ & $\begin{array}{l}5.30^{*} \\
(2.54)\end{array}$ & $\begin{array}{l}-1.92 \\
(4.25)\end{array}$ \\
\hline Normal recession & $\begin{array}{l}-0.71 \\
(1.60)\end{array}$ & $\begin{array}{l}-0.20 \\
(1.92)\end{array}$ & $\begin{array}{l}2.95 \\
(2.30)\end{array}$ & $\begin{array}{l}1.01 \\
(2.04)\end{array}$ & $\begin{array}{c}1.25 \\
(1.90)\end{array}$ \\
\hline Non-financial macro disaster & $\begin{array}{l}-1.48 \\
(2.10)\end{array}$ & $\begin{array}{l}-0.14 \\
(3.78)\end{array}$ & $\begin{array}{l}1.89 \\
(3.76)\end{array}$ & $\begin{array}{c}2.37 \\
(3.94)\end{array}$ & $\begin{array}{c}2.62 \\
(4.74)\end{array}$ \\
\hline $\begin{array}{l}\mathrm{H}_{0}: \text { Financial }=\text { normal } ; \mathrm{p} \text {-value } \\
\mathrm{H}_{0}: \text { Financial }=\text { disaster } \text { p-value }\end{array}$ & $\begin{array}{l}0.10 \\
0.09\end{array}$ & $\begin{array}{l}0.11 \\
0.33\end{array}$ & $\begin{array}{l}0.43 \\
0.56\end{array}$ & $\begin{array}{l}0.11 \\
0.59\end{array}$ & $\begin{array}{l}0.53 \\
0.49\end{array}$ \\
\hline $\begin{array}{l}R^{2} \\
\text { Observations }\end{array}$ & $\begin{array}{c}0.061 \\
921\end{array}$ & $\begin{array}{c}0.106 \\
916\end{array}$ & $\begin{array}{c}0.144 \\
910\end{array}$ & $\begin{array}{c}0.173 \\
904\end{array}$ & $\begin{array}{c}0.204 \\
898\end{array}$ \\
\hline (c) Post-WWII sample & Year 1 & Year 2 & Year 3 & Year 4 & Year 5 \\
\hline Financial recession & $\begin{array}{l}1.30^{*} \\
(0.65)\end{array}$ & $\begin{array}{l}1.13 \\
(1.80)\end{array}$ & $\begin{array}{l}-0.52 \\
(3.53)\end{array}$ & $\begin{array}{c}1.04 \\
(3.58)\end{array}$ & $\begin{array}{c}9.84^{* * *} \\
(2.41)\end{array}$ \\
\hline Normal recession & $\begin{array}{c}1.58 \\
(1.11)\end{array}$ & $\begin{array}{l}1.80 \\
(1.53)\end{array}$ & $\begin{array}{c}2.80 \\
(1.77)\end{array}$ & $\begin{array}{c}1.83 \\
(1.41)\end{array}$ & $\begin{array}{c}2.37 \\
(1.53)\end{array}$ \\
\hline Non-financial macro disaster & $\begin{array}{l}-0.10 \\
(1.21)\end{array}$ & $\begin{array}{l}5.15 \\
(7.96)\end{array}$ & $\begin{array}{l}8.31 \\
(9.54)\end{array}$ & $\begin{array}{l}11.96 \\
(8.02)\end{array}$ & $\begin{array}{l}12.63 \\
(7.90)\end{array}$ \\
\hline $\begin{array}{l}\mathrm{H}_{0}: \text { Financial }=\text { normal } ; \mathrm{p} \text {-value } \\
\mathrm{H}_{0}: \text { Financial }=\text { disaster } ; \mathrm{p} \text {-value }\end{array}$ & $\begin{array}{l}0.74 \\
0.28\end{array}$ & $\begin{array}{l}0.76 \\
0.63\end{array}$ & $\begin{array}{l}0.42 \\
0.40\end{array}$ & $\begin{array}{l}0.83 \\
0.20\end{array}$ & $\begin{array}{l}0.01 \\
0.73\end{array}$ \\
\hline $\begin{array}{l}R^{2} \\
\text { Observations }\end{array}$ & $\begin{array}{c}0.068 \\
1226\end{array}$ & $\begin{array}{c}0.124 \\
1206\end{array}$ & $\begin{array}{c}0.168 \\
1186\end{array}$ & $\begin{array}{c}0.211 \\
1166\end{array}$ & $\begin{array}{l}0.253 \\
1146\end{array}$ \\
\hline
\end{tabular}

Notes: ${ }^{* * *}$ Significant at $.01 .{ }^{* *}$ Significant at .05. ${ }^{*}$ Significant at .1. Robust standard errors (clustered by country) in parentheses. Results correspond to local projections of cumulative change in 100 times the logged variable relative to peak for years 1-5 of the financial recession (first row), normal recession (second row), and non-financial macro disaster (third row). The top panel (a) covers the years 1870-2014, the middle panel (b) covers the years 1870-1938, and the bottom panel (c) covers the years 1950-2014. World War I years (1914-1918) and World War II years (1939-1949) are excluded. Financial $=$ normal tests the null that coefficients for each type of recession are the same for the intercept terms in the first and second rows. Financial $=$ disaster tests the null that coefficients for each type of recession are the same for the intercept terms in the first and third rows. In each case the p-value of the test is provided. The controls are contemporaneous and 1-year lagged values of the growth rate of GDP per capita and the CPI inflation rate at peak (coefficients not reported). See text. 
Table E5: Local projections of the no. of street protest incidents (\% deviation from trend)

\begin{tabular}{|c|c|c|c|c|c|}
\hline (a) Full sample & Year 1 & Year 2 & Year 3 & Year 4 & Year 5 \\
\hline Financial recession & $\begin{array}{c}1.32 \\
(1.13)\end{array}$ & $\begin{array}{c}4.29 \\
(2.77)\end{array}$ & $\begin{array}{c}11.14^{* *} \\
(5.05)\end{array}$ & $\begin{array}{c}20.57^{* *} \\
(7.60)\end{array}$ & $\begin{array}{l}21.46^{*} \\
(10.31)\end{array}$ \\
\hline Normal recession & $\begin{array}{c}0.62 \\
(0.58)\end{array}$ & $\begin{array}{c}0.24 \\
(1.46)\end{array}$ & $\begin{array}{l}-1.05 \\
(2.04)\end{array}$ & $\begin{array}{l}-2.53 \\
(2.64)\end{array}$ & $\begin{array}{l}-3.44 \\
(2.41)\end{array}$ \\
\hline Non-financial macro disaster & $\begin{array}{c}1.32 \\
(1.51)\end{array}$ & $\begin{array}{c}1.58 \\
(4.13)\end{array}$ & $\begin{array}{l}-1.15 \\
(6.14)\end{array}$ & $\begin{array}{l}-6.95 \\
(8.00)\end{array}$ & $\begin{array}{l}-2.90 \\
(6.61)\end{array}$ \\
\hline $\mathrm{H}_{0}$ : Financial $=$ normal; $\mathrm{p}$-value & 0.61 & 0.27 & 0.05 & 0.01 & 0.03 \\
\hline $\mathrm{H}_{0}$ : Financial = disaster; $\mathrm{p}$-value & 1.00 & 0.63 & 0.18 & 0.05 & 0.06 \\
\hline $\begin{array}{l}R^{2} \\
\text { Observations }\end{array}$ & $\begin{array}{c}0.612 \\
1560\end{array}$ & $\begin{array}{c}0.522 \\
1520\end{array}$ & $\begin{array}{c}0.441 \\
1480\end{array}$ & $\begin{array}{l}0.409 \\
1440\end{array}$ & $\begin{array}{c}0.409 \\
1400\end{array}$ \\
\hline (b) Pre-WWII sample & Year 1 & Year 2 & Year 3 & Year 4 & Year 5 \\
\hline Financial recession & $\begin{array}{l}-1.17 \\
(0.96)\end{array}$ & $\begin{array}{l}-1.20 \\
(2.66)\end{array}$ & $\begin{array}{c}0.48 \\
(4.67)\end{array}$ & $\begin{array}{c}6.07 \\
(6.83)\end{array}$ & $\begin{array}{l}10.86 \\
(8.48)\end{array}$ \\
\hline Normal recession & $\begin{array}{c}-1.98^{* *} \\
(0.86)\end{array}$ & $\begin{array}{l}-1.61 \\
(2.25)\end{array}$ & $\begin{array}{l}1.86 \\
(3.73)\end{array}$ & $\begin{array}{c}3.63 \\
(4.97)\end{array}$ & $\begin{array}{c}6.97 \\
(5.47)\end{array}$ \\
\hline Non-financial macro disaster & $\begin{array}{l}-1.24 \\
(1.08)\end{array}$ & $\begin{array}{l}-2.98 \\
(3.21)\end{array}$ & $\begin{array}{l}-3.47 \\
(6.32)\end{array}$ & $\begin{array}{l}-8.73 \\
(9.66)\end{array}$ & $\begin{array}{l}-1.74 \\
(8.18)\end{array}$ \\
\hline $\mathrm{H}_{0}$ : Financial = normal; p-value & 0.61 & 0.92 & 0.85 & 0.81 & 0.74 \\
\hline $\mathrm{H}_{0}$ : Financial $=$ disaster; $\mathrm{p}$-value & 0.97 & 0.67 & 0.63 & 0.24 & 0.29 \\
\hline $\begin{array}{l}R^{2} \\
\text { Observations }\end{array}$ & $\begin{array}{c}0.874 \\
356\end{array}$ & $\begin{array}{c}0.791 \\
336\end{array}$ & $\begin{array}{c}0.739 \\
316\end{array}$ & $\begin{array}{c}0.731 \\
296\end{array}$ & $\begin{array}{c}0.760 \\
276\end{array}$ \\
\hline (c) Post-WWII sample & Year 1 & Year 2 & Year 3 & Year 4 & Year 5 \\
\hline Financial recession & $\begin{array}{c}1.35 \\
(0.86)\end{array}$ & $\begin{array}{l}5.27^{\text {** }} \\
(2.41)\end{array}$ & $\begin{array}{c}14.44^{* *} \\
(5.27)\end{array}$ & $\begin{array}{c}28.77^{* * *} \\
(9.59)\end{array}$ & $\begin{array}{c}29.66^{*} \\
(16.34)\end{array}$ \\
\hline Normal recession & $\begin{array}{c}2.06^{* *} \\
(0.73)\end{array}$ & $\begin{array}{c}2.32 \\
(1.44)\end{array}$ & $\begin{array}{c}0.43 \\
(2.11)\end{array}$ & $\begin{array}{l}-0.29 \\
(2.47)\end{array}$ & $\begin{array}{l}-1.84 \\
(2.70)\end{array}$ \\
\hline Non-financial macro disaster & $\begin{array}{c}3.74 \\
(2.33)\end{array}$ & $\begin{array}{c}7.57 \\
(5.43)\end{array}$ & $\begin{array}{c}6.26 \\
(6.40)\end{array}$ & $\begin{array}{c}4.35 \\
(7.02)\end{array}$ & $\begin{array}{c}3.86 \\
(10.08)\end{array}$ \\
\hline $\mathrm{H}_{0}$ : Financial $=$ normal; $\mathrm{p}$-value & 0.58 & 0.39 & 0.04 & 0.01 & 0.08 \\
\hline $\mathrm{H}_{0}$ : Financial = disaster; $\mathrm{p}$-value & 0.40 & 0.74 & 0.39 & 0.08 & 0.19 \\
\hline$R^{2}$ & 0.544 & 0.468 & 0.397 & 0.378 & 0.381 \\
\hline Observations & 1204 & 1184 & 1164 & 1144 & 1124 \\
\hline
\end{tabular}

Notes: ${ }^{* * *}$ Significant at $.01 .{ }^{* *}$ Significant at .05. ${ }^{*}$ Significant at .1. Robust standard errors (clustered by country) in parentheses. Results correspond to local projections of cumulative change in 100 times the logged variable relative to peak for years $1-5$ of the financial recession (first row), normal recession (second row), and non-financial macro disaster (third row). The top panel (a) covers the years 1919-2012, with World War II years (1939-1949) being excluded, the middle panel (b) covers the years 1919-1938 and the bottom panel (c) covers the years 1950-2012. Financial = normal tests the null that coefficients for each type of recession are the same for the intercept terms in the first and second rows. Financial = disaster tests the null that coefficients for each type of recession are the same for the intercept terms in the first and third rows. In each case the p-value of the test is provided. The controls are contemporaneous and 1-year lagged values of the growth rate of GDP per capita and the CPI inflation rate at peak (coefficients not reported). See text. 